\title{
THE CHEMICAL DEFENSES OF MILLIPEDES (DIPLOPODA): BIOCHEMISTRY, PHYSIOLOGY AND ECOLOGY
}

William A. Sheara

aDepartment of Biology, Hampden-Sydney College, Hampden-Sydney VA 23943, USA

Email: wshear@hsc.edu

\section{Abstract}

Millipedes are some of the earliest examples of terrestrial animals, and fossils from the early Carboniferous Period indicate they were also some of the earliest prey. These fossils record ozopores, the openings of chemical defense glands, occurring along the length of the body. The secretions of these glands may consist of topical irritants, repellents, antifeedants, or, in the case of the large and widespread Order Polydesmida, hydrogen cyanide ( $\mathrm{HCN}$ ) gas that can be fatal to other arthropods or even small vertebrates in a confined environment. Müllerian mimicry rings may develop in which unrelated species of millipedes that co-occur closely resemble one another, while participating in a completely differently patterned ring in another part of their geographic range. Chemistry is not the only defense of millipedes. Polyxenids carry tufts of entangling setae, many species rely on crypsis and the ability to roll into a smooth, resistant sphere or coil, and still others have spikey projections that may deter soft-mouthed predators. Nevertheless, chemical defense has been of significance in helminthomorph millipedes at least since the Lower Carboniferous. The distribution of classes of chemical defense compounds follows major phylogenetic groupings. Evidence suggests that the defensive glands of Glomerida arose independently of those of the Helminthomorpha.

Keywords: allomones, cyanogenesis, quinones, alkaloids, spiropyrrolizidine oximes, quinazolinone alkaloids 


\section{Introduction}

The earliest evidence of chemical defense by an arthropod consists of ozopores on the segments of fossil millipedes from the Devonian and Visean (Lower Carboniferous) of Scotland (Shear 1994, Shear and Edgecombe 2010, Wilson 2006). The earliest review of millipede chemical defenses, a remarkably prescient one, was written by O. F. Cook in 1900. In this essay, Cook mentioned the stickiness of polyzoniid secretions, discussed the use of millipedes by primates for self-anointing, and postulated that there were at least four different classes of compounds involved. The facts about millipede chemical defenses were last effectively reviewed in English by Blum (1981), and by Eisner et al (1978). Popular accounts of several species were provided by Eisner and Eisner (2005), and Demange (1993) produced a summary in French. Since the early 1980s, the defensive substances of many additional species have been characterized-more than 140 species have now been studied, in contrast to the 56 listed by Eisner et al (1978). Improved analytical methods have allowed the discovery of components present in extremely small amounts and the estimation of the percent composition of secretions. We also know more about the various chemoecological roles played by millipedes, so the time seemed ripe for another comprehensive review of the subject, and that is the purpose of this article.

\section{Classes of secretions}

The defensive substances produced by millipedes cannot be characterized as a whole, because entirely different classes of molecules are produced by different taxa. Table 1 lists as completely as possible the species that have been studied so far, their chemical products, and literature citations for the identification. Eight classes of compounds, sometimes widespread, or restricted to one taxon or a few related ones, can be recognized. In each case only a few, usually more recent, references are given in the listing below; more complete, older references may be found in Eisner et al (1978) and Table 1. Structural formulae for some of these compounds are shown in Figs. 1 and 2.

Quinazolinone alkaloids, glomerin and homoglomerin (Fig. 1K, L), are produced by the two species of glomeridans that have been studied up to this time (Schildknecht et al 1966; Meinwald et al 1966; Shear et al, 2011).

Heterocyclic nitrogen-containing compounds have been detected from members of the Order Polyzoniida. These include polyzonimines (Fig. 1M), nitropolyzonamines (Fig. 1N), buzonamine and spiropyrrolizidine oximes (Meinwald et al 1975; Kuwahara et al 2007).

Terpenes such as pinenes and limonene have also been found in polyzoniidans as well as in the siphonophoridans examined, where they are not accompanied by polyzonimines and others listed just above (Shear \& Jones, unpublished data; see Table 1). 
Benzoquinones and hydroquinones (Fig. 1J, Fig. 2) with numerous substitutions (largely methyl and/or methoxy groups) have been recorded from many species in the orders Spirobolida, Julida, and Spirostreptida. 2-methyl-3methoxy-1,4-benzoquinone occurs almost universally in these species and is generally the greatest component where a mixture is found (Attygale et al 1993; Buden et al 2004; Sekulic et al 2014).

Fatty acid esters and a few other aliphatic compounds occur in conjunction with quinones, and may serve as solvents or themselves be aversive (Shimizu et al 2012).

Aliphatic compounds (i.e., Fig. 1B) including [E]-2-octenal have recently been reported from one species of julidan in conjunction with benzoquinones (Bodner \& Raspotnig 2012). 1-octen-2-ol was found in the secretion of the polydesmidan Niponia nodulosa (Omura et al 2002a)

Phenols (including o-cresol [Fig. 1G], p-cresol [Fig 1H], and guaiacol [Fig.1I]), are produced by callipodidans (i.e., Curcic et al 2009; Shear et al 2010; Makarov et al 2010), by stemmiulidans (Shear and Jones, unpublished data), by one parajulid julidan (accompanied by benzoquinones), and by some polydesmidans, where, except in a few cases, they are secreted in addition to cyanogenics (Taira and Arakaki 2002; Shear et al 2007).

Cyanogenics such as mandelonitrile (Fig. 1D) and benzoyl cyanide (Fig. 1E) make up the main defenses of all but a few polydesmidans. When secreted, the cyanogenics are mixed with an enzyme that degrades them to HCN and benzaldehyde (Fig. 1C) or benzoic acid (many authors; see Eisner et al 1978, also Omura et al 2002b).

A number of compounds have been found as "one-off" in a variety of species; the status of these compounds is at present uncertain since the results have not been duplicated by other investigators, or were obtained by methods less reliable than those now in use. These compounds are in bold type in Table 1. Of particular interest is the detection of (1E)-2-nitroethylbenzene and (1Z)-2-nitroethylbenzene in the doratodesmid polydesmidan Eucondylodesmus elegans by Kuwahara et al. (2002). This species evidently lacks the usual cyanogenic system of the Polydesmida. We have found similar compounds in two New Zealand dalodesmids, but one of them also had the cyanogenic system (Shear \& Jones, unpublished data). Clearly more investigations of dalodesmids and doratodesmids are warranted.

\subsection{Unpublished results}

Research in collaboration with T. H. Jones and others has preliminarily characterized the secretions of members of the orders Platydesmida, Siphonocryptida, Siphnophorida and Stemmiulida, which up to this time have 
remained unknown. They are included in Table 1 and in the discussions below pending publication of the details. Species in the orders Polyxenida, Sphaerotheriida and Chordeumatida, are, to the extent of present knowledge, devoid of at least exocrine chemical defenses. Some doubt has been expressed regarding the absence or presence of chemical defenses in Glomeridesmida, but Shear et al (2007) examined a species of Glomeridesmus using scanning electron microscopy and found no evidence of ozopores, and there are no primary reports of chemical defenses in this order.

\section{Repugnatorial glands}

Eisner et al (1978) recognized three types of glands in millipedes: the median, two-armed glands in Glomeridae, the bilateral, bipartite glands of the Polydesmida, and bilateral single-chambered glands, differing in shape, from the other orders with chemical defenses. The orders Polyxenida, Glomeridesmida, Sphaerotheriida and Chordeumatida lack glands.

\subsection{Type 1}

Shown in Fig. 3, and found only in Glomerida (Eisner et al 1978, and references therein; Shear et al 2011). The gland openings are mid-dorsal, transverse slits in the inter-ring cuticle just anterior to rings 4-11 (though the glands themselves are located in the preceding ring); the pores do not open within the ring as shown by Eisner et al (1978, fig. 2A), but at least in Glomeris marginata the anterior margin of the ring just posterior to the pore is modified (see Fig. 3, Shear et al 2011). In the North American Onomeris sinuata, the tergite margin is unmodified (Shear et al 2011, Fig. 5). In Glomeris marginata, the glands consist of two widely diverging arms that come together just anterior to the pore. Each gland is irregularly wrapped with a thin layer of muscles which become thicker and presumably specialized close to the pore. It is not known if the glands are lined with cuticle or not. The viscid product of the glands is presumably ejected by the contraction of the muscles lining the glands.

\subsection{Type 2}

Similar glands are found in Polyzoniida, Platydesmida, Callipodida, Julida, Spirostreptida and Spirobolida (gland anatomy of Stemmiulida, Siphonophorida and Siphonocryptida is unknown). The glands (Fig. 4) are bilaterally paired and open on either side of all rings including and posterior to ring five or six (depending on the order). The glands consist of a thin layer of secretory epithelium lined on the inner side with cuticle, suggesting that the glands form as epidermal invaginations. The cells do not secrete into common ducts, but each cell has its own cuticle-lined duct that empties directly into the cavity (see discussion of histology below). The glands are usually semispherical, but appear to be elongate in the polyzoniids and long, narrow tubes in the platydesmids. A narrow duct proceeds from each gland to the ozopore; just interior to the pore is a plug-like valve operated by a single muscle 
that attaches to the ring cuticle just anterioventral to the valve. The glands are not muscularized and so the secretion either simply oozes out upon the opening of the valves, or is forced out, evidently by the contraction of the inter-ring musculature (Eisner et al 1978, Demange 1993, and references therein; Arab et al 2003). This type of gland may have been present in millipedes as early as the Devonian Period, when millipedes now preserved as fossils may have had paired, segmental ozopores (Wilson 2006).

\subsection{Type 3}

This type of apparatus (Fig. 5) is found only in the order Polydesmida. The distribution of the glands along the body rings is not continuous; the most common pattern is to have bilaterally paired glands on rings $5,7,9,10,12,13$, and 15 through 19 (typically the trunk of a polydesmidan consists of 20 rings, including the anterior legless collum and the posterior legless preanal ring). There are erratically distributed departures from this arrangement throughout the order and a few species have been reported to lack ozopores entirely. Internally, the gland consists of the usual large epithelial sac similar to Type 2 , which elaborates a cyanophore (usually either mandelonitrile or benzoyl cyanide); no musculature is associated with this part of the apparatus. A short duct connects the gland or reservoir to a second chamber, much more heavily lined with cuticle, which Eisner et al (1963) dubbed the vestibule. Between the reservoir and the vestibule is a muscularized valve similar to the one close to the ozopore in Type 2 glands. Thus the control of secretion is vested in this valve and the actual ozopore is always open. The valve between the reservoir and the vestibule allows secretion precursor from the reservoir to enter the vestibule. Cells surrounding the vestibule release an enzyme which catalyzes the dissociation of mandelonitrile to benzaldehyde and HCN. As Eisner et al (1978) postulated, this type of apparatus can be seen as developing from Type II by the invagination of the vestibule from the region of the ozopore, pushing the valve to the interior.

\section{Histology of the glands}

The histology of the glands has not been studied very thoroughly; the most detailed work to date using light microscopy being that of Weatherston and Percy (1969). Woodring and Blum (1963) and Eisner et al (1963) examined Type 3 glands at a gross histological level. The histology of type 1 glands has not been looked at at all. What histological work has been done focuses on Type 2 glands.

\subsection{Histology of Type 2 glands}

Weatherston and Percy (1969) found that the gland cells of Uroblaniulus canadensis (Julida, Parajulidae) were not continuous in lining the gland, but were interspersed among the hypodermal cells that secrete the procuticular lining of the gland. There appeared to be two types of gland cells arrayed in not more than about 20 pairs. Cell A has a large nucleus and highly vacuolated cytoplasm; centrally there 
is a clear vesicle in which a tubule originates. The tubule, lined with cuticle, continues into the cytoplasm of cell B, in which it passes through a second vesicle to which many fine filaments attach from the cytoplasm; this led Weatherston and Percy (1969) to hypothesize that this second vesicle collected secretion from the cytoplasm, but the abundant vacuoles found in cell A were not present in cell B. The tubule exits cell B and continues to a sieve plate on the inner side of the gland epithelium, which it shares with tubules from the other cell pairs. Similar cuticular tubules were found by Eisner et al (1978) in examples of spirobolids, callipodids and polydesmidans, as they resisted digestion by KOH. Woodring and Blum (1965) examined the gland cells of Orthocricus arboreus (Spirobolida, Rhinocricidae) and stated that the gland cells formed a continuous layer, but they also evidently did not see tubules; it appears that more species need to be examined to establish whether or not the patterns found in U. canadensis are widespread.

Eisner et al (1978) lamented that electron microscopy had not been applied to the study of the secretory cells of millipede defensive glands, but evidently they missed the work of Tichy (1974). Tichy (1974) generally confirmed the findings of Weatherston and Percy (1969) with transmission electron microscopy. Using an unidentified species of Pachyiulus (Julida, Julidae), he found two types of adjacent cells, one of which was responsible for the secretory function (corresponding to cell A) and the other forming the tubule (corresponding to cell B), but instead of being merely adjacent, the tubule cell was smaller than the secretory cell, which surrounded it except where it was appressed to the lining of the gland duct. The secretory cell contained abundant Golgi ("dictyosomes") which produced many small vesicles; these coalesced and eventually made their way to the large vesicle of the secretory cell and thence through the tubule to the lumen of the gland. Sieve plates were not detected.

The available evidence seems to indicate that the gland cells are modified hypodermal cells, and that at least the Type 2 and 3 glands are invaginations of the cuticle-secreting ectoderm.

\section{Synthetic pathways}

\subsection{Sequestration hypothesis}

Relatively few species have been investigated thoroughly, but enough have to be able to state with some confidence that millipedes synthesize their own defensive substances and do not sequester them from their diets. Meinwald et al (1975) suggested that polyzoniids sequestered their alkaloid secretions from plants, reasoning that the mandibles of these millipedes were adapted to "scrape" plant tissue. But the reduced mandibles of polyzoniid millipedes may have numerous functions, polyzoniids live in the soil, and have never been observed to feed on living plants. The idea of sequestration was from the first questionable, since millipedes are detritivores that rarely eat living plant material and thus would be unlikely to 
seek out particular plant species from which they could obtain and sequester chemicals. Nevertheless, this suggestion still surfaces (Clark et al 2005, repeating the assertions of Meinwald et al 1975). The possibility remains that at least a few species may feed on fungi and sequester compounds from them, since 1-octen-3-ol and geosmin found in Japanese Niponia nodulosa (Polydesmida, Cryptodesmidae) also occur in fungi (Omura et al 2002a). However, Omura et al (2002a) doubted this idea. Detailed studies on in vivo synthesis of the compounds found in millipede defensive secretions are few, but frequently in vitro syntheses are carried out to confirm the identities of the compounds (i.e., Smolanoff et al [1975] for polyzonimine [Fig. 8] and Mori et al [2000] for polyzonimine and nitropolyzonamine).

\subsection{Quinazolinone alkaloids}

Glomerin and homoglomerin are quinazolinone alkaloids secreted by at least two species of Glomeridae (Shear et al 2007). Similar alkaloids are known from plants, and the synthetic drug Quaalude is also a quinazolinone alkaloid with notable sedative properties. The synthesis of glomerin and homoglomerin (Fig. 6) was studied by Schildknecht and Wenneis (1967). They provided Glomeris marginata with radioactive $\left({ }^{14} \mathrm{C}\right)$ anthranilic acid, and found that about $1 \%$ of the radioactivity could be recovered in glomerin. Hydrolyzing glomerin to $\mathrm{N}$ methylanthranilic acid resulted in the same specific activity and showed that the radioactive label stayed in the expected position. Anthranilic acid was utilized because it is a known precursor of quinazolinone alkaloids in plants, but the appearance of radioactivity in glomerin and homoglomerin in their experiments demonstrated that these alkaloids were not sequestered from plants (contra the suggestion of Carrel [1984]), though the natural source of anthranilic acid for the millipedes remains unknown. In the two glomerids that have been studied, the secretion is notably adhesive (see Fig. 3B, Eisner et al 1978, and Shear et al 2011). The stickiness is due to proteins. No detectable odor is produced.

\subsection{Hydroquinones and benzoquinones}

All arthropods are capable of producing hydroquinones, which are used to "tan" or crosslink the proteins in the cuticle, giving it increased strength, similar to the process used to make leather from rawhide. Since the gland cells of quinonesecreting millipedes are presumably derived from hypodermal cells, relatively few synthetic steps would be required to produce the fifteen or so benzoquinones and hydroquinones that have so far been discovered in these millipedes. Deml and Huth (2000) presented a diagram (see Fig. 2) which illustrated possible pathways to the array of hydroquinones and benzoquinones they found in Telodeinopus aoutti (Spirostreptida, Spirostreptidae) and an unidentified harpagophorid. Hydroquinone itself was central to their scheme and they showed how it could, by simple metabolic steps, be converted into the other compounds they detected. Deml and Huth (2000) suggested that either tyrosine or $p$-hydroxybenzoic acid could be 
the metabolic precursor of hydroquinone. Duffey and Blum (1977) suggested that benzoquinone could be synthesized from tyrosine via phenol and arbutin.

\subsection{Cyanogenesis}

The general subject of cyanogenesis in plants and animals was reviewed by Zagrobelny et al (2008). For most polydesmidan millipedes, the production of benzaldehyde and HCN results from the enzyme-catalyzed dissociation of mandelonitrile. Towers et al (1972) fed ${ }^{14}$ C labelled D, L-phenylalanine to the polydesmidan Oxidus gracilis (Paradoxosomatidae) and recovered radioactivity in both HCN and benzaldehyde in the millipedes' secretions (Fig. 7). Duffey et al (1974) and Duffey and Towers (1978) studied the entire synthetic pathway in the polydesmidan Harpaphe haydeniana (Xystodesmidae). They traced radioactivity from ${ }^{14} \mathrm{C}$ phenylalanine through phenylacetaldoxime and phenylacetonitrile to mandelonitrile. This is essentially the same synthesis procedure used in cyanogenic plants. Mandelonitrile is stored in one chamber of the two-part gland and subsequently used in an enzyme-catalyzed reaction in the second chamber to produce benzaldehyde and HCN. The enzyme was identified as alpha-hydroxynitrile lyase (Duffey and Towers 1978). The $\mathrm{pH}$ in the reaction chamber $(\mathrm{pH}=4)$ was the optimum for this enzyme. Casnati et al (1963) found a number of different organic acids in the secretion of Pseudopolydesmus (Polydesmida, Polydesmidae); an acid environment in the storage chamber would be necessary to stabilize stored mandelonitrile. Nevertheless, some of the mandelonitrile would continuously and spontaneously degrade to benzaldehyde and HCN, a danger to the millipede. Harpaphe haydeniana was able to detoxify both benzaldehyde (to $p$-hydroxybenzoic acid) and HCN (to beta-cycloalanine and asparagine), a process also used in plants (Duffey \& Towers 1978).

Mandelonitrile is the cyanogen in most polydesmidans, but benzoyl cyanide is also found in the secretion of members of the family Xystodesmidae, representing up to $30 \%$ of the secretion. Benzoyl cyanide has its own distinctive, and repellent, odor, which is noticeable in the field when handling some of these millipedes. Other compounds identified included mandelonitrile benzoate, ethyl benzoate, benzoic acid. phenol and guaiacol (Duffey et al 1977). More sensitive analytical methods have allowed researchers to make distinctions between the compounds secreted by related species of xystodesmids, as well as their proportions (Omura et al 2002b).

Duffey and Blum (1977) studied the synthesis of phenol and guaiacol in Oxidus gracilis. Both were produced from the amino acid tyrosine by specific lyases. Tyrosine phenol lyase was localized in the region of the cyanogenic glands of the millipedes and was stored in the reservoir, not the reaction chamber. Similar mechanisms were demonstrated for Pseudopolydesmus erasus and Euryurus maculatus (Duffey and Blum 1977).

The unusual 2-nitroethyl benzenes secreted by at least some doratodesmids are synthesized from L-phenylalanine (Kuwahara et al 2002). 


\section{Methods of dispensing secretion}

\subsection{Glomeridans}

In the case of the glomeridans (with Type 1 glands), the secretion is expelled by the contraction of the muscles wrapping the glands, and oozes out in droplets that remain intact on the dorsal surface of the animal, which by this time has likely enrolled, with its head and legs completely protected (illustration in Carrel and Eisner 1984). It appears from the photograph that all the glands discharge simultaneously. Carrel and Eisner (1984) found that the amount of secretion relative to body weight was remarkably constant, equal to about $0.15 \% \pm .02 \%$. Carrel (1984) depleted the secretions of individuals and determined that recharge time was quite long, requiring as much as four months to replenish their secretions to the full amount, which means that the millipedes may be able to discharge their secretions only a few times in the course of a year. Shear et al (2011) found that Onomeris sinuata was very reluctant to secrete in response to rough handling and discovered the quinazolinones only by extracting whole animals. Onomeris sinuata is a very small glomerid that lives in the soil and unlike some Glomeris species is not aposematic. Ants are probably its main predators and the secretion may be released only if the millipede detects some clue to the presence of ants.

\subsection{Juliforms}

Juliform millipedes (with Type 2 glands) appear either to simply allow the secretion to flow passively out of the ozopores, whence it quickly spreads over the surface of the animal, or to eject the secretion as a stream or spray (Barth 1967; Eisner et al 1978; Ubik et al 1982; Burden et al 2004). Spraying appears to be limited to larger species of the orders Spirobolida and Spirostreptida; the secretion can be propelled up to $50 \mathrm{~cm}$ (Eisner et al 1978). Eisner et al (1978) speculated that either increased haemolymph pressure, or pressure from nearby segmental muscles might be responsible for the spraying, since the glands of these millipedes are not muscularized. Barth et al (1967) noted that spraying was accompanied by strong contractions of the body or by a writhing motion and that this contraction provided the motive force. Not much quantitative data is available, but large spirobolids or spirostreptids may contain 200-300 mg of benzoquinones, small julids as little as 1 mg (Schildknecht and Weiss 1961; Eisner et al 1978). In the case of Narceus gordanus (Spirobolida, Spirobolidae), a localized stimulus first results in secretion by glands in the stimulated region; the response then spreads along the body in both directions (Eisner et al 1978, Fig. 5).

\subsubsection{Benzoquinone liquifaction}

A significant question about the way in which the benzoquinones characteristic of this group of millipedes are ejected has to do with the observation 
(Attygale et al 1993) that these substances are solids at environmental temperatures. How are they liquefied? Attygale et al (1993) suggested that specific mixtures of benzoquinones and hydroquinones could spontaneously liquefy due to mixed melting point depression. However, Huth (2000) rejected this idea because the ideal ratios required are not present in the eight species studied by her, and that the ratios in all species studied up until 2000 varied extensively. She also noted that small but significant amounts of aliphatic compounds were present in the secretions. Shimizu et al (2012) detected $n$-hexyl laurate and fourteen other fatty acid esters from Anaulaciulus sp. (Julida, Julidae) and noted that aliphatics had previously been reported from many species but were often dismissed as being due to the extraction of fatty acids from the body or from the cuticle (Sekulic et al 2014), but their experimental protocol precluded this explanation. The esters were part of the secretion. In insects, aliphatics are often present in defensive secretions along with benzoquinones and serve as solvents for the latter, and Shimizu et al (2012) suggested this was the case with millipedes as well. Weatherston, Tyrell and Percy (1971) had previously published this idea.

\subsection{Polydesmidans}

In the case of cyanogenic polydesmidans, the secretion oozes from the ozopore after having been mixed with enzymes in the vestibule, as described above. The mix of mandelonitrile or benzoyl cyananide with the enzyme then produces HCN and benzaldehyde or benzoic acid for as long as 30 minutes (Eisner et al 1963). Kuwahara et al (2011) reported that four species of polydesmidan millipedes from Japan did not require enzymes to produce HCN from benzoyl cyanide. HCN and mandelonitrile benzoate developed from the secretion by means of a SchottenBauman reaction, which also took place in vitro in the absence of any enzyme activity.

Duffey et al (1977) noticed that ozopore diameter in xystodesmids did not keep pace with vestibule volume and thought that vapor pressure in the vestibule as reaction proceeded could be a force in ejecting the secretion; the smaller pore would restrict flow and make vapor pressure more effective.

\subsubsection{Role of phenolics in polydesmidans}

Phenolics are often a subsstantial component in the secretion of cyanogenic polydesmidans (Table 1), and in a few cases seem to either replace or strongly supplement that system. Blum (1981) speculated that these components made up an "early warning system" that would induce experienced predators to drop the millipede before being exposed to HCN. In some polydesmidans such as Leonardesmus injucundus (Nearctodesmidae) and others, cyanogenesis is absent and the millipedes rely on the powerful repellent odor of phenolic compounds, which can be detected by humans about $2 \mathrm{~m}$ away, though the millipedes are only about $1 \mathrm{~cm}$ long (Shear et al 2007). 
Millipedes are attacked by ants, beetles (both adults and larvae), predaceous bugs, spiders, slugs (Herbert 2000), and visually hunting vertebrates such as birds, mammals, reptiles and amphibians (Cloudsley-Thompson 1949). As Eisner et al (1978) indicated, "there can be no doubt that the defenses [of millipedes] are effective," and documented their claim with numerous references, to which can be added Duffey et al (1977), Minch (1978), Olivieri et al (2001), and Capone et al (2002, 2005).

\subsection{Modes of action}

Almost no systematic studies on the exact mode of action of millipede defensive secretions have been carried out since the review of Eisner et al (1978), who also found only a few reports and based their account largely on previously unpublished work by Eisner and his collaborators. Clearly some of the components, such as benzoquinones, phenolics and polyzonimine are repellents. Typical experiments to demonstrate this involve allowing ants to feed at a sugar source and then presenting a small amount of the test compound near the sugar. Rapid dispersal of the ants demonstrates the repellent effect (Smolanoff et al 1975, Eisner et al 1978). Eisner (1970) also thought that many of the compounds, especially benzoquinones, could act on predatory insects as irritants through the "common chemical sense." It has been repeatedly demonstrated that benzoquinones are highly irritating to vertebrates, not only to mucous membranes and the eyes, but also to intact skin (Eisner et al 1978; see also the section below on human effects). Conner et al (2007) found support for the selection of an array of arthropod allomones, including benzaldehyde and quinones, by the chemosensitivity of vertebrate trigeminal receptors.

Loomis (1936) reported that it was common knowledge among natives of Hispaniola that large spirobolidan millipedes could blind chickens and other animals with their sprayed secretions.

\subsubsection{Toxicity of secretions}

Some secretions may actually be toxic. Mousstache et al (1969) injected quinones from Rhinocricus varians (Spirobolida, Rhinocricidae) into mice; it killed $13 / 25$ animals, causing a rapid drop in blood pressure. However, it is unlikely that quinones would affect a predator in nature by this route. Experiments in which benzoquinones or intact millipedes were administered orally to rats elicited no ill effects, so the benzoquinones were probably quickly neutralized by reactions with gut fluids (Kinkel 1955, Eisner et al 1978). There is no question that HCN is a potent toxin. A single Apheloria millipede weighing about one gram can produce up to $600 \mu \mathrm{g}$ of HCN, 18 times the lethal dose for a $300 \mathrm{~g}$ pigeon and six times that of a $25 \mathrm{~g}$ mouse; however, this amount is only 0.4 the lethal dose for a frog the same weight 
as the mouse (Eisner et al, 1967; see also Nishio et al [1995])). It is a common observation that confinement in a small space, such as a collecting jar, with a polydesmidan millipede can be fatal to insects and even small vertebrates (i.e., Stebbins 1944).

The high toxicity of glomerin and homoglomerin to mice when administered orally or intraperitoneally was demonstrated by Schildknecht et al (1967), who also showed that strong negative reactions were elicited from mice, birds and amphibians who fed on Glomeris marginata. Quinazolinones are known to be sedative and are structurally similar to the synthetic sedative, Quaaludes. Carrel and Eisner (1984) found that six species of wolf spiders (Lycosidae) from Florida were sedated by glomerin from Glomeris marginata. This reaction may be quite specific, since one of the wolf spider species, Schizocosa ceratiola, was not sedated by the related quinazolinones arborine and methyqualone (Carrel et al 1985). However, as pointed out by Shear et al (2011), this study was somewhat flawed because Glomeris marginata occurs only in western Europe, and the spiders used were from the southern United States. The sedative effect, if it has significance in defending Glomeris marginata, may be secondary, as both glomerin and homoglomerin were potent antifeedants against the spiders at much lower concentrations than were required to sedate them. The extreme bitterness of these substances may thus be the most important of their qualities in defending millipedes from spiders (Schildknecht et al 1966).

\subsubsection{Physical actions of secretions}

Stickiness of secretions has also been demonstrated to play a role in millipede defense. Glomeris marginata secretion contains proteins that are very adhesive and the secretion comes away in threads if touched. Ants become tangled and even glued to the substrate (Schildknecht et al 1967, Eisner and Meinwald, 1966). The secretion of Petaserpes cryptocephalus (= Polyzonium rosalbum in Meinwald et al [1975]); Polyzoniida, Polyzoniidae) is also sticky, which was attributed by Blum (1981) at least in part to the nitropolyzonimine component. Marek et al (2012) reported sticky material exuded by Illacme plenipes (Siphonophorida, Siphonorhinidae), but it appeared to come from metatergal setae, not the ozopores. In passing, Chamberlin (1923) remarked that another siphonophoridan (Siphonophora pearsi) could also produce sticky threads, but did not specify the source.

\subsection{Targets of secretions}

Targets of the defensive chemicals may vary. Peterson (1986) found that HCN alone did not repel ants, even to the point that the ants remained in the vicinity until they were killed, but benzaldehyde was strongly repellent. It may be that polydesmidans need defense against both insect and vertebrate predators, with benzaldehyde repelling ants and HCN working primarily against vertebrates. Leonardesmus injucundus (Polydesmida, Nearctodesmidae) is a small, litter-dwelling 
millipede that is not cyanogenic but produces $p$-cresol, a strong repellent for ants. Due to its cryptic habitat and small size, this species is not likely to be preyed on by vertebrates (Shear et al 2007). Niponia nodulosa (Polydesmida, Cryptodesmidae) is not cyanogenic as are the majority of polydesmidans, but produces 1-octen-3-ol and geosmin, neither of which repel ants, but which may be directed at other predators (Omura et al 2002a). The possum Didelphis albiventris reacts somewhat aversely to the odors of millipedes, but eats them anyway (Santori 1998), and a tortoise, Kinixys spekii, eats large spirostreptids without any ill effects (Haley et al 2001). Millipede secretions may not always work if they are specialized to repel only certain predators.

\subsection{Cyanide resistance}

Polydesmidan millipedes are highly resistant to their own secretions of HCN (Blum 1981). The mechanism is not, as originally thought, an ability to close their spiracles and shut down much of their metabolism, but lies in the millipede's cytochrome oxidase system, which, by an undefined mechanism, resists cyanide poisoning (Hall et al 1971, Duffey et al 1974). The cytochromes of Euryurus leachii (Euryuridae) are much more tolerant of cyanide than those of a cockroach (Hall et al 1969). Harpaphe haydeniana (Xystodesmidae) detoxifies HCN by converting it first to beta-cyanoalanine and then to asparagine (Duffey and Towers 1978). Oxidus gracilis (Paradoxosomatidae) possesses the enzyme rhodanese, which transforms HCN into the harmless thiocyanate ion (Duffey and Blum 1977).

\section{Aposematism and mimicry}

Aposematic coloration is often associated with animals that provide unpleasant or harmful consequences to their predators. Predators thus come to associate, via individual learning, certain colors and patterns with these negative experiences, such that they avoid them. Although these signals are known to be visual in millipedes, instances of auditory and olfactory aposematism are documented in other arthropods, and it remains unknown whether predators can detect the odor of defense secretions at a distance. The colors and patterns are directed at visually hunting predators, and tend to be very obvious, most often in the form of stripes, spots or patches of red, orange, yellow or white against a black background. This is the paradox of aposematism: it makes the prey conspicuous to their predators. For a complete analysis, see Ruxton et al (2004).

\subsection{Aposematic coloration}

Aposematic coloration in millipedes (Figs. 9-15) is generally limited to species with relatively large body size, that are day-active or that are likely to be uncovered during the day by visual hunters. Species such as the North American representatives of Callipodida have powerful defensive chemicals ( $p$-cresol) but are dull brown or black; they spend almost all their time under leaf litter and if they 
appear on the surface at all, it is at night (personal observations). The most obvious (one might even say blatant) and best known examples of aposematism are among the polydesmidans, such as species of the families Xystodesmidae (Fig. 16), Chelodesmidae (Fig. 11) and Paradoxosomatidae (Fig. 13), and in tropical species of the orders Spirobolida (Figs. 9, 12) and Spirostreptida. Curiously, aposematism in members of those latter orders living in temperate climates is somewhat subdued and appears more pattern-based, while xystodesmids in temperate North America provide some of the best examples of aposematism, with a diversity of colors and distinct patterns. As with many other aposematic arthropods, the signals take the form of bands or spots of long wavelength colors (e.g. yellows, reds, oranges) or white against a dark or black background. In xystodesmids, for example, the most common patterns are paranotal spots, three spots (including paranotal spots and a median spot on each ring), and bands along the posterior margin of the metaterga. Bands and paranotal spots may be combined, as with the common Apheloria virginiensis corrugata of eastern North America, with yellow bands and red paranotal spots. In tropical spirobolids, it is not uncommon for the legs to contrast strongly in color with the trunk. The endemic Mexican and Central American family Rhachodesmidae includes species in which the entire body is bright yellow, red or orange, as well as some in which the color is uniformly vivid blue or green (Fig. 14), often with white paranotal spots (personal observations). The significance of the blue and green patterns is not understood; I found blue Strongylodesmus sp. rhachodesmids highly resistant to using their chemical defenses, if they have any (ozopores and glands are present but I detected no odor). The key function of aposematic signals is to reduce recognition errors with edible prey and to appear as distinct as possible against their visual background (Mallet \& Joron 1999). This explains why typically short wavelength hues like blue and green are not used, since they blend in with the visual background, but in the case of blue rhachodesmids these colors may not be common in their microhabitat.

\subsection{Bioluminescent aposematism}

In a small area of the southern Sierra Nevada in California, eight species of the xystodesmid genus Motyxia occur (Shelley 1997), and are the only bioluminescent millipedes (Fig. 16), though most or all species of xystodesmids fluoresce under UV light. These millipedes produce low-intensity bluegreen light (Davenport et al 1952) at a wavelength of $495 \mathrm{~nm}$ which slowly grows brighter if the millipedes are disturbed (Hastings and Davenport, 1957). The first examination of these millipedes with respect to their light-producing properties was carried out by Hastings and Davenport (1957). While they provided some detail on the physics and chemistry of the light, they were unable to elucidate the biochemical mechanism by which it was produced. Later, a photoprotein was identified with porphyrin as a component of its chromophore (Shimomura 1984). Causey and Tiemann $(1969,1970)$ investigated the systematics and natural history of Motyxia (=Luminodesmus) but attributed no function to the light. Fairhurst (1993) stated that the defensive secretions of "some cave millipedes" were luminous, but I can find 
no evidence for this elsewhere. It is likely that Fairhurst was confusing millipedes with centipedes, some of which do produce a luminous secretion.

Marek et al (2011) suggested that the light produced by Motyxia was an aposematic signal adapted to be used at night, when the millipedes were active on the surface. Motyxia species spend the daylight hours concealed in litter or in the soil, and do not show any obvious aposematic coloration. To test this hypothesis, Marek et al (2011) utilized live millipedes and detailed clay models. Both live millipedes and models were presented as luminescent and darkened versions (the live millipedes were painted with opaque paint to conceal their light). The millipedes and models were staked out over transects and arranged randomly. Grasshopper mice (Onychomys torridus) were the most likely predators, and left bite marks on the clay models or partially consumed live millipedes. In both the models and the millipedes, attacks on the dark or darkened examples were more frequent, to a highly significant statistical degree, supporting the aposematic hypothesis.

\subsection{Mimicry}

Aposematism leads to protective mimicry, generally thought of as being of two types. In classical Batesian mimicry, harmless organisms adopt the patterns of protected species and thereby share in their protection. Müllerian mimicry results when sympatric protected species converge on a common color pattern and thereby spread out the costs of educating predators. Both kinds of mimicry can coexist, and the likelihood of Batesian mimicry is enhanced by the presence of Müllerian rings (Ruxton et al 2004).

\subsubsection{Batesian mimicry by millipedes}

Batesian mimicry by millipedes has not been much studied. Obviously this alternative would be available to chemically undefended millipedes sharing a habitat with defended, aposematic species. This may be the case in some vividly colored but chemically undefended sphaerotheriidans found in Madagascar (Fig. $15)$, where they coexist with the aptly named fire millipedes, aposematic spirobolidans (Wesener et al 2007). Levi (1965) suggested that Glomeris pulchra in Dalmatia mimics the sympatric venomous spider Latrodectus mactans, which displays a ventral red spot on a glossy black, subspherical abdomen, presenting a similar appearance to an enrolled Glomeris with red dorsal spots. At the time of Levi's writing, the chemical defenses of Glomeris marginata had not been studied, and he may have been unaware of them. Based on our present knowledge, this case might better have been interpreted the opposite way: spiders downed from their webs might benefit by resembling the chemically defended glomerids. Levi (1965) also noted that the armadilliid isopod Armadillidium klugii, occurring in the same area, was roughly the same size as Glomeris pulchra, enrolled in a sphere and was glossy black with red spots. Schmalfuss (2013) has evaluated Levi's hypothesis from the viewpoint of the isopod specialist and expressed doubts that the isopod was mimicking the spider. It seems more likely to be mimicking the glomerid. 


\subsubsection{Batesian mimicy of millipedes}

The mimicry of millipeds by other animals is likewise supported by only a few cases. Leonard and Stebbins (1999) thought that the snake Contia ternis might mimic sympatric parajulids (Julida) by balling up when disturbed and displaying a ventral pattern of gray-crossbanding. Diploglossus lessonae, a Neotropical lizard, may be a mimic of the sympatric Rhinocricus albidolimbatus, and the congeneric $D$. fasciatus may likewise mimic an unidentified Rhinocricus with a yellow banding pattern (Vitt 1992). The peculiar Bornean centipede Edentistoma octosulcatum is distinctly millipede-like, with a slow gait, ridged and rigid tergites, and distinct marginal yellow bands on each black segment, but its habits are largely unknown (Vahtera and Edgecombe 2014).

\subsubsection{Müllerian mimicry}

Müllerian mimicry among sympatric, chemically defended millipedes has been repeatedly suggested in a general way. Hoffman (1971) was the first to postulate a specific case, suggesting that Brachoria hoffmani and Apheloria virginiensis corrugata were mimics in the area around Haysi, Virginia, while at nearby Wytheville, B. hoffmani resembled Appalachioria separanda versicolor. Whitehead and Shelley (1992), based on extensive fieldwork by Whitehead, delineated further cases at several additional localities, described characteristic patterns and colors, and built a solid framework for more detailed investigation. They also noted that mimicry may not be limited to dorsal pattern; since xystodesmids roll up when disturbed, exposing the legs laterally, leg coloration is also involved (Figs. 9,11). Of the patterns they described, they thought the banded pattern plesiomorphic, but did not provide evidence for this idea.

\subsubsection{Müllerian mimicry in Xystodesmidae}

Marek and Bond (2009) carried out a study of Müllerian mimicry in apheloriine xystodesmids that has become a standard, textbook example of this phenomenon and is also one of the most complete analyses of Müllerian rings ever performed. They studied seven apheloriine species in the central Appalachian Mountains. The distributions of these species overlap to varying degrees so that as many as five of the species may be sympatric and indeed may be found within the same $50 \mathrm{~m}^{2}$ patch of forest. Each species varies in color and pattern geographically, but co-occurring species appear identical. The authors proposed four predictions based on Müllerian mimicry theory: 1) that the co-occurring species share the same aposematic signal, 2) that the shared signal is not due to relatedness, 3) that rarer species tend to mimic the most abundant or more highly defended species, and 4) that the mimicry varies geographically following the model's geographic variation. The first prediction was fulfilled when it was found that detailed spectral measurements of color and reflectivity were more similar among the suspected mimics at one site than those compared to the same species at other sites. To test 
the second prediction, Marek and Bond (2009) compiled a phylogeny of apheloriine millipedes and mapped color pattern and geography on the tree, showing that relatedness of the species could not account for the similarities in color pattern. Prediction three was tested using field data on collection frequency. An unnamed species of Apheloria (Apheloria clade A) was found to be the most abundant by a significant margin at 10 of 17 sites, and therefore was likely the model at those sites. With this hypothesis supported, the fourth prediction was also fulfilled, since the variation in the mimics was shown by a photographic analysis to track the variation in the model (Fig. 17). Marek and Bond (2009) drew further postulates from their study, such as the effect of population density and genetics, which remain to be examined in detail. This model study might readily be implemented with other taxa suspected of participation in Müllerian rings.

\section{Strategies for overcoming millipede chemical defenses}

Not surprisingly, predators respond evolutionarily to prey defense mechanisms, resulting in an "arms race." Predators on millipedes are no exception, and not only are there millipede specialists, but some predators and parasites have evolved means of using the defensive secretions to find millipedes.

\subsection{Ants}

The ant Gnamptogenys ingeborgi was observed by Brown (1992) in Colombia. He collected a small nest of this ant and noted that empty rings from millipedes were present in the midden. The nest was transported to Ithaca, N. Y., and experiments were carried out with local millipedes. An unidentified juliform was attacked by the ants, but repelled them with its secretions, the ants reacting frantically and spending considerable time grooming themselves. When the ants were presented with the polydesmidan Oxidus gracilis, however, a different scenario ensued. About 20 trials resulted in the following summary. The attacking ant mounted the millipede and stung it between rings, which killed the millipede almost immediately. Gnamptogenys transported the prey to the nest in a characteristic way, holding the prey just behind and under the head, and slinging the trunk over its own body. After attacking and during transport, the ant groomed itself frequently. Once at the nest, the millipede was decapitated and larvae were placed on it, which consumed it ring by ring. Intrigued by this different reaction to different millipedes, Brown (1992) tried another experiment. He depleted a juliform of its secretion, washed it, and then wiped secretion from Oxidus on it. The juliform was immediately attacked and killed by an ant, quite a different result from the frantic behavior seen when the juliform was able to use its own secretions. However, the ant was unable to decapitate the millipede and it was abandoned. This single experiment was hardly conclusive, but Brown was led to suggest that the ants were in fact attracted by the secretion of Oxidus gracilis.

\subsection{Phendodid beetle larvae}


Perhaps the best known millipede specialist predators are phengodid beetle larvae (Fig. 18), including Zarhipis integripennis, studied by Tiemann (1967). The beetle larvae actively hunt large millipedes (Tiemann illustrates attacks on Atopetholus michelbacheri [Spirobolida, Atopetholidae] in California). On encountering a millipede the larva runs alongside it and eventually bites the millipede just under the head, which is then removed prior to feeding. The larva enters the millipede anteriorly and eats it ring by ring. While Tiemann (1967) was most interested in the beetles, Eisner et al $(1998,2005)$ focused on the millipedes, in this case Floridobolus penneri (Spirobolida, Floridobolidae) being attacked by Phengodes laticollis in Florida. The behavior of $P$. laticollis is similar to that of $Z$. integripennis, but Eisner et al (1998) established that the initial bite by the larva results in the injection of a toxin through its hollow mandibles. The millipede is paralyzed almost immediately and is unable to open the valves of its repugnatorial glands. The beetle enteric fluid also digests the soft tissues, which are sucked up by the beetle larva, leaving the intact exoskeleton behind, including the cuticle-lined defensive glands still containing their benzoquinones.

\subsection{Other insects; centipedes}

Carabid beetles of the genus Promecognathus may be millipede specialists, at least one species in western North America attacking cyanogenic xystodesmids (LaBonte 1985). It is not known how the beetles avoid the millipedes' defenses. The bizarre, millipede-like centipede Edentistoma octosulcatum has been photographed in Borneo preying on an aposematic Trachelomegalus species, evidently unaffected by the millipede's quinone-based defense (Vahtera and Edgecombe 2014).

\subsection{Mastigoproctus}

Floridobolus is also successfully attacked by the sympatric tailed whip scorpion Mastigoproctus giganteus, but it is not known how the whip scorpion resists the chemical defenses of the millipede (Carrel and Britt 2009). Whip scorpions are themselves chemically defended by the production of acetic acid, but are protected from its effects by their waxy cuticle (Eisner et al 2005). This property of the cuticle may also protect the predator from millipede benzoquinones.

\subsection{Attraction of parasitoids}

Coincidental to their observations on phengodid predation on Floridobolus, Eisner et al (1998) also noted that when one millipede in the field was induced to discharge its secretions, many individuals of the fly Spirobolomyia (Diptera, Sarcophagidae) quickly appeared. The fly is a parasitoid of the millipede and may use the secretion as a signal to locate hosts. An African phorid fly attacks large odontopygid millipedes in Africa. When the millipedes detect the flies, they thrash vigorously about but do not release benzoquinones. Disney and Ritchie (1967) 
speculated that the flies use the millipede's secretions to find them, hence the millipedes' reluctance to release them. Hash (2014) observed two species of the phorid fly genus Megaselia in Costa Rica that were attracted to, and fed on, the defensive secretion of the polydesmidan Nyssodesmus python (Rhachodesmidae). The secretion, as with most polydesmidans, consists of mandelonitrile, benzaldehyde and HCN (Shear and Jones, unpublished data). These flies exhibit "fluid-dropping" behavior, in which the posterior abdominal segments are extended and fluid droplets are ejected. Hash (2014) noted that all phorids showing this behavior feed on toxic hosts and that it is possibly a way of dealing with host toxicity. The flies did not oviposit on the millipedes and lack a "parasitic-type" oviscape (Hash 2014).

\subsection{Carrion-feeders}

Carcasses are rich but relatively rare and spotty resources. Carrion feeding insects may be highly sensitive to chemical cues that guide them to new food. Brühl and Krell (2003) and Krell et al (1997) note that in many regions of the tropics, the carcasses of large millipedes are an important resource exploited by many genera and species of scarabaeoids, some of which are generalists and a few of which seem to specialize on dead millipedes (Krell 1999, 2004). In Borneo, Brühl and Krell (2003) baited traps with toilet paper onto which they had induced spirostreptidan millipedes (Spissustreptus sp., Harpagophoridae) to secrete benzoquinones. The traps drew in four species of generalist carrion beetles. They thought that responding to the odor of the secretions would allow the beetles to reach the cadavers earlier, before competitors who relied on emenations due to decay. Schmitt et al (2004) repeated similar experiments in Ivory Coast, using not only natural secretions obtained from local spirobolidans (Pelmatojulus tigrinus, Pachybolidae) but also an array of synthesized benzoquinones known to occur in the secretions of $P$. tigrinus, as well as other benzoquinones as controls. Thus they were able to show that a mixture of 2-methoxy-3-methyl-1,4-benzoquinone and 2methyl-1,4-benzoquinone was the most effective bait in attracting Onthophagus beetles. The mixture consisted of the two most important components of the Pelmatojulus secretion, and the beetles are specialists in millipede scavenging (that is to say, they prefer millipedes but are sometimes found on other carrion). Large millipedes are common in the study region, and the beetles, by being attracted to and resisting the benzoquinones, are able to exploit this resource efficiently (Schmitt et al 2004).

Not only benzoquinones, but benzaldehyde from polydesmidans also attracts certain carrion-feeding beetles. In Vera Cruz, México, Bedoussac et al (2007) baited traps with the millipede Amplinus bitumidus (Polydesmidae, Aphelidesmidae) and captured many individuals of the scarabaeid Canthon morsei. These experiments were followed up by laboratory tests which demonstrated that benzaldehyde attracted the beetles. In the field tests, the beetles preferred A. tumidus carcasses to dead fish! The beetles avoided eating the repugnatorial glands of the millipedes. 


\subsubsection{Carrion-feeders transition to predation}

Larsen et al (2008) noticed that the Peruvian scarabaeid Deltochilum valgum had been observed grasping live millipedes. Experiments with baited pitfall traps established that this species of beetle was attracted exclusively to millipedes and showed a distinct preference for live, but injured, individuals, which it would kill and eat. The millipedes were not identified. The beetles show morphological adaptations (compared to closely related dung-feeding species) for transporting and feeding on millipedes, and have completely abandoned the dungball-rolling habit of their congeners. Larsen et al (2008) thought that the beetle's ancestors had perhaps first switched to carrion-feeding on millipedes, attracted by the defensive secretions. This may have been followed by a second niche shift to specializing on live, but injured, millipedes which would produce more secretions, hence a stronger chemical cue. Similar observations were reported from Thailand by Kon et al (1998). It is not known how the beetles avoid the defensive secretions, but since they feed primarily on liquid or semiliquid food, the chitinous lining of the sacs may remain intact.

\subsection{Reduviidae}

In India, the reduviid bug Haematorrhophus nigroviolaceus (Reduviidae, Etrichodiinae) preys exclusively on millipedes. In an ingenious set of experiments using models, Haridass and Ananthakrishnan (1980) showed that the sight of a moving, cylindrical object triggered predatory behavior in the bug. The effect was enhanced if the model had been scented with millipede (Trigoniulus, Spirobolida, Pachybolidae) defensive secretions. The millipedes are larger than the bugs, and try to escape by running, dragging the bugs along, until, 12-15 seconds later, the millipedes are paralyzed by the toxic saliva of the bugs. Before feeding, the bugs clean themselves vigorously by rubbing on the substrate. Again it is not known how the bugs avoid the repugnatorial glands, but since they liquefy the contents of the prey, it is likely that the cuticle lining the glands prevents them from being breached.

According to Forthman and Weirauch (2012), all 600 or more species of Etrichodiinae in 123 genera appear to be millipede specialists (Fig. 19). Reviewing the literature and discussing their own observations at La Selva, Costa Rica, they found that etrichodiines prefer to attack juliform (benzoquinone-producing) millipedes rather than polydesmidans (cyanide producers). They found no information in the literature to indicate how the bugs find or discriminate among millipede prey. Once millipedes are located, the attack focuses on intersegmental membranes, and the millipedes are paralyzed if not killed. In a number of species adults and nymphs feed communally. Rhiginia cinctiventris, the species they studied in Costa Rica, is conspicuously aposematic, as are many other etrichodiines, but the nature of their own chemical defense remains unknown. Forthman and Weirauch (2012) speculated that it might be possible the bugs sequester the defensive chemicals of the millipedes. 
Vertebrates may also develop techniques for overcoming chemical defenses. Weldon et al (2006) reported that coatis (Nasua spp.) kill large millipedes (probably spirobolidans and spirostreptidans) by vigorously rolling them on the ground using their forepaws. They thought that this behavior would deplete and wipe off the quinones secreted by the millipedes under attack. Indeed, experiments showed that this behavior was actually elicited from coatis by 1,4-benzoquinone, 2-methyl-1,4benzoquinone and 2-methoxy-3-methyl-1,4-benzoquinone, the main components of juliform millipede defensive secretions. Kinixys spekii, a tortoise in Zimbabwe, eats many millipedes, usually first biting off the heads, but if the millipedes coil, the tortoise bites at the outermost rings. Chemical defenses appeared to be without effect (Hailey et al 2001). Eisner et al (1978) found that if frogs or toads captured millipedes with their tongues and swallowed them immediately, the millipedes' secretions had no effect. But if the toad had to manipulate the millipede, giving it time to discharge its glands, the prey was rejected and the same toad was reluctant to attack another millipede (Eisner and Eisner 1965).

\subsection{1. "Robespierre"}

Eisner et al (1978) first alluded to "Robespierre," a unknown predator in northern North America that bites off the heads and first few segments of Narceus millipedes, thereby consuming the parts that are not chemically defended. Melman (pers. comm. 2005 et seq.) discovered many beheaded Narceus on an island off the Massachusetts coast where the millipede was extremely abundant; this, too, looked like the work of "Robespierre," but efforts to definitively identify the predator were to no avail. The most likely candidates are shrews or grasshopper mice, but in laboratory tests, Eisner et al (1978) found that local shrews and grasshopper mice either ignored millipedes or were repelled by them. The identity of "Robespierre" remains a mystery.

\section{Other possible functions of secretions}

Two major additional functions have been postulated for the defensive secretions of millipedes: antimicrobiosis and communication.

\subsection{Antimicrobiosis}

It has long been known that quinones and hydroquinones have potent antibacterial properties (Geiger 1946). Phenol (as "carbolic acid") was one of the first substances used as a distinfectant and antiseptic. Roncadori et al (1985) tested the secretions of the polydesmidans Cherokia georgiana (Xystodesmidae), Euryurus leachii (Euryuridae) and Oxidus gracilis (Paradoxosomatidae) for antifungal activity. The fungi used were isolated from the cuticles and feces of the millipedes 
themselves, and from their habitats. Benzoic acid and benzaldehyde were shown to strongly inhibit spore germination. Omura et al (2002a) noted that 1-octen-3-ol, produced by Niponia nodulosa, is antimicrobial and antifungal. Other examples have been presented by Kuwahara et al (2002), Wu et al (2007) and Makarov et al (2014). Since most millipedes occupy habitats in which both bacteria and fungi are abundant, antibacterial and antifungal properties of their defensive secretions could be important to their survival. However, the defensive secretions are released only in response to specific threatening stimuli and are not always present; we do not know if residues of secretions on the millipede's cuticle after a defensive episode would be effective in preventing infection.

\section{2. Mites}

Millipedes are also hosts to both parasitic and commensal mites. CloudsleyThompson (1949) reported mites feeding on the repugnatorial secretions of millipedes, but this has never been confirmed. Indeed, Gerdeman et al (2000) showed that the secretions of Narceus annularis killed its associated mites.

\subsection{Pheromone functions}

The possibility that the defensive fluids could also act as pheromones has been raised repeatedly, but without much evidence (Eisner et al 1978). Haacker (1972) suggested that the secretions may be sexual attraction pheromones, but later changed his view (Haacker 1974), deciding instead that the release of repugnatorial secretions by females effectively signaled female unreadiness for mating. Niponia nodulosa is a polydesmidan that lacks cyanogenesis and instead secretes geosmin and 1-octen-3-ol, which Omura et al (2002a) found did not repel ants. However, the secretion does repel conspecifics, and they thought it could function as an alarm pheromone.

\subsubsection{Aggregation}

Aggregations of large numbers of millipedes (Fig. 21) have frequently been reported and may occur with some regularity in many species (reviewed in Hopkin and Read 1992, pp. 167-170). Bellairs et al (1983) made a detailed study of the phenomenon in the Indian polydesmidan Streptogonopus phipsoni (Paradoxosomatidae). In experimental tests, they found that high concentrations of benzaldehyde caused aggregations of the juvenile millipedes to disperse, but that weak concentrations $\left(10^{-6}\right)$ were attractive. Concentrations as low as $10^{-8}$ could be detected by the millipedes. Bellairs et al (1983) postulated that during aggregation, the millipedes continuously produced very small amounts of secretion, but if one individual discharged its glands, this stimulated others nearby to do the same, raising the local concentration of benzaldehyde. The aggregation would then disperse. In air, benzaldehyde quickly oxidizes to benzoic acid and the concentration would fall. At a certain point, attraction would take over and the aggregation would reform, producing a neatly calibrated system of communication 
not unlike the trail pheromones of ants. The paradoxosomatid Chamberlinius hualienensis is another aggregating millipede; mass migrations occur in Okinawa twice during the life cycle, once in an immature stage and again as adults (Taira and Arakaki 2002). Noguchi et al (1997b) had previously demonstrated that the composition of the defensive secretion of this species changed with age. Taira and Arakaki (2002) quantified the changes and found that females as juveniles produced more of all of the components of the defensive secretion than did males. P-phenol, the major component, was most strongly female-biased, and the difference persisted into adulthood. It is possible that these changes may be connected with the timing of the migrations of the millipedes.

While several millipede species in at least three orders show a tendency for seasonal or cyclic aggregation and/or migration, many members of the platydesmidan familes Andrognathidae and Platydesmidae show aggregation on a more or less permanent basis (i.e., Lewis 1984) and in Platydesmus and Brachycybe species, the aggregations consist of all growth stages (Fig. 20). A curious feature of the aggregations is the tendency to form "rosettes," in which the millipedes gather in a circle, head to head. The biology of these species has yet to receive comprehensive study, but they are chemically defended (Shear and Jones, unpublished data) and it is possible the aggregations form through a pheromone-like function of the defensive secretions.

\section{Relations with other species}

\subsection{Self-anointing by birds}

Since millipede defensive secretions are copiously produced and highly effective repellents of ants and other insects, it is not surprising that other animals sharing their environments have evolved behaviors exploiting these qualities. The phenomenon of "anting" by birds is well-known: birds rub themselves with ants so that chemicals produced by the ants will repel or kill their ectoparasites (Simmons 1966, Ehrlich et al 1986). Not only ants, but fruits and other scent-laden materials are used. Some bird species have discovered the virtues of millipedes for "anting." Parkes et al (2003) briefly summarize a number of cases involving such birds as the strong-billed woodcreeper (Xiphicolaptes), little shrike-thrush (Colluricincla), jungle myna (Acridotheres), european robin (Erithacus) and two species of trumpeters (Psophia), among others. Most of the observations identify the millipedes only vaguely, but it appears that juliforms, with their quinone secretions, are most frequently used. In the case of the strong-billed woodcreeper they observed in Belize, however, the millipede was a cyanogenic polydesmidan, Aceratophallus $\mathrm{sp}$. (Rhachodesmidae). Both spirostreptidans and polydesmidans were used by another species of Xiphicolaptes in Brazil (Sazima 2009). These woodcreepers often ate the millipede after its secretions had been depleted. 


\subsection{Self-anointing by primates}

There have also been numerous reports of primates self-anointing with millipedes (examples and citations in Carrel et al 2005; see also table in Enghoff et al 2014). Again, quinone-secreting millipedes were most commonly used. Valderrama et al (2000) reported wedge-capped capuchin monkeys (Cebus olivaceous) rub themselves with Orthoporus dorsovittatus (Spirostreptidae); the monkeys avidly seek out the millipedes and share them among themselves, as many as four monkeys using the same millipede. Weldon et al (2003) made similar observations on Cebus appea and C. capucinus, and also found that the most common quinones in Orthoporus secretions elicit the monkeys' behavior since they also wiped themselves vigorously with filter paper treated with secretion. Similar experiments and observations by Zito et al (2002) on three species of owl monkeys (Aotus sp.) produced similar results.

\subsubsection{Effectiveness of self-anointing}

Weldon et al (2003) tested the effectiveness of the benzoquinones against the yellow-fever mosquito, Aedes aegypti. Their results showed that the benzoquinones reduced landing behavior and inhibited feeding in the mosquitos, even killing a number of them. Lone star ticks (Amblyomma americana) were also tested for responses to benzoquinones by Carrel et al (2005). 2-methoxy-3-methyl1,4-benzoquinone showed some repellent activity, and this and other benzoquinones produced behavioral anomalies in the ticks that lasted up to 3 months after treatment, depending on concentration. Carrel et al (2005) concluded that "benzoquinones appropriated during anointing may reduce the tick loads of free-ranging animals."

\subsection{Poison frogs}

Brightly colored, aposematic poison frogs in the neotropics, Africa and Madagascar sequester as many as 800 different alkaloids from their diets (Saporito et al 2006, 2009). Many of these alkaloids have been identified as coming from mites and ants or other insects on the frogs' menu (Daly et al 1994, 2000). It has been repeatedly suggested that at least three of the alkaloids, polyzonimine, nitropolyzonamine and SpiroP $O$-methyloxime 236 are obtained from millipedes, especially siphonotids (Polyzoniida) that co-occur with the frogs. Specifically, the widespread synathrope Rhinotus purpureus, found in the habitat of poison frogs in both Central America and Madagascar (Wesener 2014) has been implicated. However, other siphonotids also occur in both those regions. Rhinotus purpureus has been shown to produce both nitropolyzonamine and SpiroP $O$-methyloxime 236 (Saporito et al 2003). So far, these compounds have been found only in siphonotid millipedes and poison frogs. The evidence for the millipedes as a source for the alkaloids in the frogs is mostly circumstantial at this time, based on co-occurrence and the seeming exclusivity of the chemicals to the two taxa. For example, in Panama Saporito et al (2003) examined the gut contents of poison frogs and found 
only a single millipede-but that millipede was not a siphonotid. Clark et al (2005), working in Madagascar, field-collected only a single specimen of $R$. purpureus. Again, only a single millipede was found among the frogs' gut contents, a specimen of Prosopodesmus jacobseni (Polydesmida, Haplodesmidae). The defensive chemistry of $P$. jacobseni is not known, but it is likely cyanogenic. The chemical profiles of the frogs did not exactly match that of $R$. purpureus. Because the frogs predominantly eat ants and mites (Clark et al 2005) and because the inventory of alkaloids produced by tropical ants and mites is far from complete, it remains a possibility that the siphonotid alkaloids are also produced by some species of ant or mite, and this is the source for the frogs.

\subsection{Inquilines in ant colonies}

A few species of millipedes occur as inquilines in the nests of ants, and species of Calymmodesmus (Polydesmidae, Pyrgodesmidae) have been observed running with the raiding columns of army ants in Central America (Loomis 1959). The millipedes are ignored by the ants, but the ants also seem not to be repelled by them. Rettenmeyer (1962), who observed these millipedes, picked several of them up and could detect no odor or secretion from those he handled. Only one pyrgodesmid has been examined chemically, but this family is peculiar in having their ozopores raised on stalks, above the soil or debris that usually coats their bodies, so one would suppose their chemical defenses are important to them.

\section{Millipedes and humans}

\subsection{Millipede "burns"}

Quinones, as already emphasized, are strong irritants to the skin and mucous membranes of vertebrates, and humans are not excepted. Millipede taxonomist $\mathrm{H}$. F. Loomis was collecting millipedes on the island of Hispaniola when he disturbed a large Rhinocricus lethifer, which sprayed its defensive secretion some 18 inches upward into Loomis' face and left eye, causing intense pain. Loomis reported that his eyelid and cheek were painful and swollen for several hours, and the next day the affected skin had turned brown and blistered. A week later, the skin peeled, leaving no scars, and Loomis reported no permanent vision problems (Loomis 1936). Burtt (1947) summarized human encounters with millipede secretions up to that time. Subsequent reports include those of Halstead and Ryckman (1949), Haneveld (1958), Haddad et al (1969), Radford (1979), Shpall and Frieden (1991), Hudson and Parsons (1997), and Lima et al (2010). These reports include descriptions of the effect of secretions by spirobolidans and spirostreptidans both on intact human skin and on the eyes. Since quinones are used to "tan" the cuticles of arthropods, it is not surprising that they have the same effect on human skin, which turns first a purplish shade, then brown. In most cases, any pain is transient, but if copious secretions are applied the outcome may be different; Burtt (1938) put a large Tanzanian millipede in his rear pocket and a severe blistering reaction 
resulted. Hence several of the millipede encounters cited above refer to "burns." If the spray from a large juliform strikes the eye, intense pain may be followed by temporary vision problems (Haneveld 1958). Though there are secondary reports of blindness, the outcome in all direct reports was a complete recovery.

\subsection{Millipedes as food}

Millipedes have rarely been discussed as part of the culture of human societies (but see Costa Neto 2007). Enghoff et al (2014) reported on an African tribe that eats millipedes regularly, despite their defenses. The millipedes are boiled in water filtered through wood ashes, then dried and eaten later with a locally prepared tomato sauce. Presumably the alkali from the wood ashes chemically neutralized the millipedes' defensive secretions. Analysis showed the millipedes have significant nutritional value.

\subsection{Cultural use of millipede secretions}

Pallares (1946) wrote "It had been noted that the natives of central Mexico ground a certain species of Myriapoda with plants for poisoning their arrows (Pallares 1946, p. 105)." The millipede to which Pallares referred was Rhysodesmus vicinus (Polydesmida, Xystodesmidae), which he found to be cyanogenic. However, Pallares' identification is questionable, based on his description and the fact that $R$. vicinus is a very old name that has never been pinned down to a particular species population. Pallares (1946) treated his extracts of the millipede quite roughly and $p$-isopropyl mandelonitrile degraded to cuminaldehyde, highly toxic to rabbits by the oral route, so its use as a poison is not without credibility. On the internet one finds frequent mention of the same usage of millipedes in Malaysia, and I was finally able to track this down to a citation of Costa Neto (2007), who in turn cites a Brazilian invertebrate zoology textbook as his authority for the simple statement that it happens. I did not investigate further.

Fairhurst (1993), in a very brief review of millipede defensive secretions, mentions that in correspondence with a physician in Zambia, he (the physician) had linked high levels of throat cancer with villages where "very large curled up dead millipedes" were used to scrub cooking pots.

\subsection{Pseudoparasitism}

Pseudoparasitism by millipedes is a contentious subject and has been repeatedly dismissed. Nevertheless, reports continue to appear. Ertek et al (2004) reported on a case in which numerous Nopoiulus millipedes (Julida) emerged from a boy's anus. His symptoms were attributed to the secretions of the millipedes. Mowlavi et al (2009) reported a similar case involving Brachyiulus lusitanicus (Julida, Julidae). It is difficult to believe that millipedes could survive passage of the stomach with its strong acid, and also to believe that a population could be established in the largely anoxic gut environment. 


\section{Other defensive mechanisms of millipedes}

As noted earlier in this essay, not all millipedes are chemically defended. The entire orders Polyxenida, Glomeridesmida, Sphaerotheriida and Chordeumatida lack obvious ozopores and repugnatorial glands. Chemical examination of several species of chordeumatids have not revealed any substances that would be effective in defense (Shear and Jones, unpublished data).

\subsection{Crypsis}

Many millipede species evidently rely on crypsis for defense. Among small, soil-dwelling species, dark coloration, roughened cuticle, and the ability to roll up or coil so that legs and antennae become inconspicuous are common adaptations. Shear (1982) among others, has noted cuticular adaptations that allow some millipedes to accumulate dirt and debris, further concealing them from predators. Recently, Martínez-Torres et al (2011) have described Psammodesmus bryophilus (Polydesmida, Platyrhachidae), a large millipede on which several species of epizooic mosses and liverworts grow, presumably providing camouflage. Enghoff (2011) described certain regularly repeating asymmetrical color patterns in millipedes that may be cryptic, breaking up the outline of the animal.

\subsection{Enrollment}

Millipedes of several families have adaptations to allow them to roll up into spheres or flattened discs, with the head, antennae and legs entirely enclosed. Others may coil into a tight, flat spiral. Because of considerable differences in morphology, it appears the ability to roll up has developed a number of times independently. These enrolling millipedes may or may not also have chemical protection. Sphaerotheriid millipedes occur widely in the southern hemisphere, in Africa, Madagascar, India, southeast Asia and Australia. As the name of the order suggests, they are able to completely enroll into slightly flattened spheres, their heads, antennae and legs completely protected by a locking mechanism that allows the last body ring to insert behind the collum (Fig. 22). The cuticle is thick and hard; clearly this ability to roll up into a sphere that not only is very hard but is smooth and difficult to grasp is the main defense of these millipedes. Eisner and Davis (1967) offered a sphaerotheriid to various predators, including ants, birds and grasshopper mice, none of which were able to overcome the combination of the hard, smooth cuticle and the ball-like shape. However, when a millipede was presented to a banded mongoose (Mungo mungo), the animal seized the millipede between its front paws and hurled it forcefully between its rear legs against a rock, cracking the cuticle. Nine millipedes were handled this way by the same mongoose. The authors suspected that this method might also be used to break eggs, known to be eaten by the mongoose. The resemblance of the spherical millipede to an egg may have released the egg-smashing behavior of the mongoose. Sphaerotheriids also fall prey to chlamydephorid slugs, which somehow puncture the exoskeleton 
and inject a venom. The millipede dies and is easily unrolled (Herbert 2000). Unexpectedly, some sphaerotheriids appear to have aposematic coloration, with yellow, orange or red bands and spots. In the absence of exocrine chemical defenses, it may be that the millipedes are distasteful in another way, or it is possible that they are mimics of aposematically colored spirobolidans with which they share their habitat, and which produce quinones. (Wesener et al 2009).

\subsection{Spines}

A few species of polydesmidan millipedes have paranota (lateral extensions of the dorsal surface) that extend upward at an angle and are divided into sharp teeth or spikes, often supplemented by rows or groups of long spines on the dorsum. Though undemonstrated, it seems likely that these spikes deter predation by birds, reptiles, amphibians or small mammals. This adaptation has evidently arisen independently numerous times in Polydesmida. The best known examples occur among the species of the paradoxosomatid genus Desmoxytes, popularly known as dragon millipedes (Fig. 23; Golovatch and Enghoff 1994, Duc Anh et al. 2005, Enghoff et al 2007, Golovatch et al 2012, Liu et al 2014). The troglobiotic species Desmoxytes spinissima is the most extremely modified species and has long, thin, spine-like paranota directed almost vertically (Golovatch 2012, Fig. 3A). Most of its epigean congeners are strongly aposematic, being bright red, purple or pink. Enghoff et al (2007) report that in addition to the spines, D. purpurosea, the "shocking pink dragon millipede," is potently cyanogenic.

\subsection{Entangling bristles}

Polyxenidans (Fig. 24) are very small millipedes that differ in appearance from all others; they have short, soft bodies, can run relatively swiftly, and are covered with tufts of setae that give them somewhat the appearance of carpet beetle larvae (Dermestidae). They are often found under bark or running over stones. No chemical defenses have ever been demonstrated and there are no glands or ozopores. Eisner et al (1996) set up encounters between the polyxenid Polyxenus fasciculatus and the ant Xenomyrmex floridanus. When disturbed, polyxenids flare the tufts of long, silvery setae on their preanal ring. These setae have an unusual shape: they end in grappling hooks, and along their length are other hook-like projections. Eisner et al (1996) and Wüest (2002) observed that the millipedes wipe attacking ants with the tufts. Setae detach, and the grappling hooks engage setae on the ant. As the ant tries to clean itself of millipede setae, the hooks along the shaft of each seta engage those on other setae and soon the ant is entangled and often immobilized. The ants were "severely incapacitated" and several died, never being able to disentangle themselves. In theory, this defense would also work on other predatory arthropods with which the polyxenidans share their habitat. Some species of ants have developed strategies to overcome the millipedes' mechanical defense and even specialize on polyxenidans as prey. Thaumatomyrmex atrox, for example, is able to strip off the setae before eating the millipede (Brandao et al 1991) and Probolomyrmex species behave similarly (Ito 1998). 


\subsection{Entanglement in secretions}

Chordeumatidans are usually identifiable by their possession of six macrosetae on each ring, symmetrically distributed on either side of the metatergal midline (Fig. 25). The setae vary greatly in morphology, but in several taxa are long, and bear parallel grooves. These setae are set very loosely in large sockets and are movable (Youngsteadt 2008, Shear and Krejca 2011). Studying the behavior of Causeyella youngsteadtorum (Trichopetalidae), a troglobiotic chordeumatid from Arkansas, USA, Youngsteadt (2008) found that droplets of a sticky substance were produced from the setal sockets. The droplets trapped "small intruders" on the millipede's dorsum and as the grooves in the seta guided the drop to the tip, the "intruders" eventually stuck to other objects in the environment and were eliminated. The droplets were analyzed chemically and contained no defensive substances (Jones and Shear, unpublished data). Shear and Krejca (2011) published photographs (their Figs. 12, 13; see also Fig. 25 in this paper) which show similar but much larger droplets on the metatergal setae of Taiyutyla loftinae (Conotylidae). These droplets could serve a defensive function by entangling potential predators, much in the way the sticky repugnatorial secretions of some chemically defended millipedes do. Nevertheless, the spider Meta ovalis was observed feeding on Causeyella youngsteadtorum (Slay et al 2009) and Eurycea salamanders eat Pseudotremia (Chordeumatida, Cleidogonidae) millipedes-but not syntopic, chemically defended Tetracion jonesi (Callipodida, Abacionidae; Shear et al 2010). No known chordeumatidans show aposematic coloration.

\subsection{Escape}

Few millipedes are capable of running fast enough to escape their predators, though callipodidans and chordeumatidans can often navigate leaf litter and debris fast enough to elude capture by human collectors. Evans and Blower (1973) described the behavior of an African Stemmiulus (Stemmilulida, Stemmiulidae) that ran quickly, but punctuated its runs with short jumps accomplished by a sudden flexion and then extension of the trunk. The leaps could be long enough so that the millipede would "disappear" from the sensory range of small predator such as an ant. Vigorous thrashing of the body has also been noted as a response by an attacked millipede (i. e., Disney and Ritchie 1997)

\section{Speculations in systematics and phylogeny}

The goals of systematic biology are two-fold. Taxonomy attempts to produce a kind of filing system of hierarchically arranged taxa which facilitates the retrieval of data about the taxa. Phylogenetics is concerned with constructing tree-like diagrams reflecting the evolutionary relationships and histories of those taxa. To some degree, these goals are compatible, and taxonomists are generally eager to have their classifications reflect the information in phylogenetic trees. Given the 
constraints of the modified Linnaean system, this is not always possible, so most taxnomies represent compromises. In the case of the Diplopoda, neither the taxonomy nor the phylogenetics are as well-developed as might be expected for a highly diverse class of ecologically important animals. Phylogenetic research up to this time has concentrated on the ordinal level and has produced a number of conflicting hypotheses. For only two of the orders (Sphaerotheriida and Julida) have evidence-based phylogenies of families been proposed, and generic level phylogenies within families are likewise rare, and often incomplete.

Given the developing nature of millipede taxonomy and phylogenetics, the choice of a framework on which information such as the distribution of chemical defenses can be hung is somewhat arbitrary. This is not the venue for evaluating arguments about the classification or the phylogenetics of millipedes, so without further discussion, the paragraphs that follow will use the classification of Shear (2011) and the phylogenetic tree of Blanke and Wesener (2013), developed from the morphological tree of Sierwald et al (2007). For an alternative but less complete phylogeny based on genetic evidence, see Brewer and Bond (2013).

Among others, Eisner et al (1978) expressed the hope that the distribution of chemical defenses in millipedes would prove to contain taxonomic and phylogenetic evidence. In a broad sense, this hope has been fulfilled in that there is significant consistency in the distribution of chemical defenses over higher taxa. At least preliminary data (some unpublished) is now available for at least one species from each of the chemically defended orders. However, continued investigations are needed because while some orders seem to be quite uniform in their chemical profile (all Callipodida that have been examined produce $p$-cresol with trace amounts of phenol), other orders are quite diverse both in the qualitative and quantitative nature of their secretions (Julida, Polydesmida).

\subsection{Species}

At the species level, there have been few focused investigations (Omura et al $2002 \mathrm{~b}$ ). What has been found suggests that different but related species may have qualitatively similar secretory compositions, but that relative amounts may differ. In order to investigate this further, it will be necessary to consider sampling large numbers of individuals from the same populations in order to avoid confusing individual differences, and in order to be able to treat the data statistically. At the present time, methods for obtaining secretions and analyzing them vary substantially and possible differences induced by these techniques have been mentioned in the literature, but no directed study has been made (Omura et al $2002 \mathrm{~b}$ ). For example, does it matter if the secretion is collected as produced from stimulated animals, or obtained through whole-body extraction? Does the nature of the solvent (methanol, dichloromethane, etc.) make a difference?

14.2. Distribution of compounds among families. 
Table 2 represents an abstract of Table 1, condensing the distribution of secretions to the ordinal and sometimes family level. To summarize the contents:

14.2.1. Glomerida: Only two species of one family have been studied, and both produce quinazolinone alkaloids.

14.2.2. Polyzoniida: Species from three families show very similar arrays of polyzonimine, nitropolyzonamine, buzonamine, and 0-methyloxime 236. Betapinene and limonene occur as minor constituents.

14.2.3. Siphonocryptida: The single species examined produced 0-methyloxime 236.

14.2.4. Siphonophorida: Species identities are difficult to determine in this group, but our unpublished data is on at least four of them; all showed alpha- and betapinene.

14.2.5. Spirobolida: Four families from this order produced an array of substituted hydroquinones and benzoquinones, as many as six different compounds. A single species of Rhinocricidae also produced 3,3a,4,5-tetrahydro-1H-pyrrolo-[2,3b] pyridine-2,6-dione as a trace component.

14.2.6. Spirostreptida: As with Spirobolida, many of the same hydroquinones and benzoquinones are secreted.

14.2.7. Julida: Julidans are more diverse in their chemistry than the other juliform orders. 2-methoxy-3-methyl-1,4-benzoquinone is the major component in most species analyzed, along with other related quinones. Anomalous compounds from single species include hexadecyl acetate, $\Delta 9$-hexadecenyl acetate, $\Delta 9$-octadecenyl acetate from a single blaniulid, and $o$-cresol from a parajulid.

14.2.8. Callipodida: The secretions of all callipodidans so far analyzed are dominated by $p$-cresol, which in most cases appears to be the only major component.

14.2.9. Stemmiulida: At least three species produce only $p$-cresol (unpublished data).

14.2.10. Polyzoniida: While this order seems to be dominated by cyanogenic species using either mandelonitrile or benzoyl cyanide to generate HCN, a great variety of other compounds occurs, most of them phenols or phenol derivatives, including $p$ cresol. These phenol derivatives seem to crop up most frequently in Paradoxosomatidae. Species that lack cyanogenesis entirely appear in the families Cryptodesmidae, Doratodesmidae, Pyrgodesmidae, Dalodesmidae and Nearctodesmidae.

14.3. Phylogenetics 
Fig. 26 illustrates the general categories of compounds mapped on the ordinal phylogeny of Blanke and Wesener (2013). The tree reveals considerable taxonomic and phylogenetic consistency in the distribution of defensive compounds. If chemical defense originated in the ancestor of Chilognatha, then it would be necessary to postulate four subsequent losses. Clearly, the lack of chemical defense in Chordeumatida represents a loss. Siphoniulida lacks ozopores, but its position in a final tree will most likely be close to Stemmiulida (Shear 2008), and the absence of glands in siphoniulids will also be shown to be a loss. The other two losses would have occurred in Glomeridesmida and Sphaerotheriidae. On the other hand, a dual origin of chemical defense, in Glomerida and the ancestor of Helmithomorpha, would require only two losses (in Chordeumatida and Siphoniulida) and so is more parsimonious. This conclusion is also supported by the strongly differing chemistry of the secretions, and divergent gland positioning and anatomy.

\subsection{1. "Quinone" millipedes}

The hypothesis of Eisner et al (1978) that the Juliforma are "quinone millipedes" is supported. However, the emerging picture of a greater chemical complexity in Juliforma (Bodner and Raspotnig 2012) suggests that the picture is more complex and conclusions must wait for more detailed data on more species (Raspotnig and Bodner 2014).

\subsubsection{Colobognatha}

Some previous analyses of diplopod phylogeny, and the classification system of Hoffman (1979) have resulted in questions about the monophyly of Colobognatha. The chemistry of the secretions of the orders in this group (Polyzoniida, Siphonophorida, Platydesmida and Siphonocryptida) does support the now generally accepted monophyly of this taxon, but in the strict consensus tree of Blanke and Wesener (2014) the four orders formed a polyotomy and relations among them remained unresolved. Although their analysis did not include Siphonocryptida, the strict consensus tree of Sierwald et al (2003) showed Plaltydesmida (Siphonophorida + Polyzoniida). Chemical data shows siphonophorids as distinct from the other three orders in producing only pinenes, but these are also present in polyzoniidans, which supports a relationship of the two orders.

\subsubsection{Polydesmida}

The largest question in millipede phylogenetics is the correct position of the Polydesmida, which classically has been placed in its own superorder Merochaeta. However, Shear et al (2003), without a matrix-based analysis, suggested an "eighth gonopod clade" consisting of Polydesmida, Callipodida, Chordeumatida and Stemmiulida. Characters supporting this hypothesis are the metamorphosis-like, abrupt development of gonopods from the eighth legpair, the vas deferens opening through the second leg coxae, and the presence of spinnerets on the telson. This 
clade is present in the analyses of Sierwald et al (2001) and Blanke and Wesener (2013) but has not been found in any analysis based on genetic data. There, the polydesmids have "bounced around" as sister to Colobognatha, to Julida, or to all other Eugnatha. However, even the most recent of these analyses (Brewer and Bond 2013) was characterized by very incomplete taxon sampling, leaving out representatives of five orders. Cyanogenesis in polydesmidans is an autapomorphy and thus uninformative, but the presence of phenol and phenolic derivatives such as cresols and guaiacol in numerous species provides a link to the cresol-producing Callipodida and Stemmiulida. Unfortunately there is no well-supported phylogeny of the families of Polydesmida, but most authorities have considered Paradoxosomatidae to be basal in the order, and it is here that phenolic compounds are most commonly found. The presence of the cyanogenic system in this putatively basal family also suggests that where cyanogenesis does not occur in the order, it is due to a loss. I would also go so far as to hypothesize that the cyanogenic system developed in response to vertebrate predation; it has been noted that HCN is not repellent to ants, and the largest producers of HCN (such as xystodesmids) display aposematic signals directed at visual predators. When cyanogenesis has been lost, it has been replaced by (possibly retained?) phenolics, and this occurs in small, cryptic species unlikely to be preyed upon by vertebrates.

Brewer and Bond (2013) did not recover a monophyletic Nematophora; instead Stemmiulida was sister to Juliforma and two of the orders of traditional Nematophora (i.e., Stemmilulida (Juliforma (Callipodida + Chordeumatida)). However, our preliminary results from at least three species of Stemmiulus gave $p$ cresol, also produced by callipodidans, and therefore provides at least some support for a monophyletic Nematophora. However, the spinnerets of stemmilulidans and siphonoiulidans, while similar to one another, differ anatomically from those of Polydesmida, Callipodida and Chordeumatida (Shear 2007).

\subsubsection{Phenol ancestral?}

The erratic presence of phenol derivatives in "quinone millipedes" and the implication of phenol in quinone synthesis may indicate that the production of phenol was the original form of chemical defense in at least eugnathan millipedes (Raspotnig and Bodner 2014). Pinenes may also be derived from phenol, but this is not so for the spiropyrollizidine alkaloids, which could represent a superimposed system such as cyanogenesis in polydesmidans. The numbers in parentheses in Fig. 26 represent a crude attempt at "mapping backwards" based on the presence of compounds in more distal branches and chemosynthetic feasibility. A statistically informative exercise in determining ancestral conditions must wait on a more detailed and stable phylogeny and on more information about the exact distribution of compounds in subordinate taxa. However, what is suggested here is that the common ancestor of Chordeumatida, Stemmiluida and Callipodida used $p$-cresol, which was lost in Chordeumatida. The common ancestor of Nematophora (if that taxon includes Polydesmida) produced phenol or a phenol derivative. The Juliforma is united by the presence of hydroquinones and benzoquinones, but phenolics have 
also been found in a subset of julidans; unless that represents an independent acquisition, phenols might have been ancestral for juliforms as well, and thus for all eugnathans. The placement of phenols on the stem of Helminthomorpha is considerably more speculative and is only based on the presence of pinenes in Siphonophorida and Polyzoniida.

\section{Future research directions}

\subsection{More data}

More exploratory research is needed. While we now have at least preliminary information on species from each of the chemically defended orders, analyzing the secretions of more species from a range of families within the orders may reveal unsuspected diversity, as indeed has happened in Polydesmida and more recently in Julida (i.e., Makarov et al 2010). A second important line of research would be to examine ontogenetic as well as phylogenetic differences in the composition of secretions; some work already done hints at changes in secretions with the age of individuals. Methodologically, we need a comparison of the several methods that have been used in the past to collect secretions. There is no study available in which a variety of methods have been applied to the same population of one species. Furthermore, good data on individual variation is lacking. Do all the members of a species produce the same chemicals in the same proportions? And are there consistent differences and/or similarities among related species?

\subsection{Synthesis}

More investigations are needed on the synthesis, or possible sources, of millipede defensive chemicals, to either lay to rest or verify the persistant suggestion that at least some of them sequester their secretions from plants.

\subsection{Anatomy and histology}

The anatomy and histology of the glands of only a few species are known. The descriptions of type 2 glands by Weatherston and Percy (1969) and by Tichy (1974) differ in many details. One wonders if the typical polydesmidan twochambered type 3 gland is retained in those species that have lost the cyanogenic mechanism.

\subsection{Interspecies relations}

The work done on mimicry rings in xystodesmids should be extended to other taxa, such as sympatric species of strongly aposematic, large, tropical juliforms. Where poison frogs obtain polyzonimine and other alkaloids they have in common with siphonotid millipedes remains an open question, given that it has not been demonstrated that the millipedes are a significant part of the frogs' diets. 
The study of arthropod chemistry in general has been a fruitful source of new natural compounds. The roles played by these compounds in ecological webs can be explored using millipedes as model systems.

\section{Acknowledgements}

Tappey Jones has for several years collaborated with me on research in chemical ecology and has continued to provide valuable guidance. I thank Henrik Enghoff, Paul Marek, Thomas Wesener and Robert Mesibov for their most useful comments on earlier versions of this review. However, any and all errors of fact or interpretation are my responsibility; I did not always take their advice! Christian Lehman prepared the illustrations involving structural formulae, and Paul Marek supplied Figs. 16 and 17, for which I thank them. I am grateful to Thomas Wesener for the use of his phylogenetic tree of the millipede orders (Fig. 26). Preparation of the manuscript and checking of references was the tedious chore of Becky Smith, whose help was and is always appreciated. Additional help organizing the tables was provided by Linda Cheyne. Preparation of this review was supported by a grant (DEB-1256139) from the National Science Foundation of the United States to the author, Jason Bond, Petra Sierwald and Paul Marek, and by grants from the Professional Development Committee of Hampden-Sydney College. 


\section{Literature cited}

Arab, A, Zacarin, G., Fontanetti, C., Camargo-Mathias, M., DosSantos, M., Cabrera, A. (2003): Composition of the defensive secretion of the neotropical millipede Rhinocricus padbergi Verhoeff 1938 (Diplopoda: Spirobolida: Rhinocricidae). Entomotropica 18 (2): 79-82.

Attygalle, A., Xu, S., Meinwald, J., Eisner, T. (1993): Defensive secretion of the millipede Floridobolus penneri. J. Nat. Prod. 56 (10): 1700-1706.

Barbetta, M., Casnati, G., Pavan, M. (1966) Sulla presenza di D-(+)-mandelonitrile nella secrezione difensiva del miriapode Gomphodesmus pavani. Mem. della Soc. Entomol. Italiana 45:169-176.

Barbier, M., Lederer, E. (1957) On the benzoquinones of the venom of three species of myriapods. Biokhymiya 22:221-225.

Barth, R. (1967) Microanatomia e citologia das gladulas penconhentas de Rhinocricus padbergii (Diplopoda). Mem. Inst. Oswaldo Cruz 65:175-195.

Bedoussac, L., Favila, M. E., López, R. M. (2007): Defensive volatile secretions of two diplopod species attract the carrion ball roller scarab Canthon moresei (Coleoptera: Scarabaeidae). Chemoecology 17:163-167.

Béhal, A., Phisalix, M. C. (1900) La quinone, preincipe actif du venin de Julus terrestris. C. r. Soc. de biol. (Paris) 52:1036-1038.

Bellairs, V., Bellairs, R., Goel, S. (1983) Studies on an Indian polydesmoid millipede Streptogonopus phipsoni: Life cycle and swarming behaviour of the larvae. J. Zool. (London) 199: 31-50.

Bernardi, M. de; Mellerio, G.; Vidari, G.; Vita-Finzi P. (1982): Quinones in the defensive secretions of African Millipedes. Die Naturwissenschaften 69: 601-602 
Blanke, A., Wesener, T. (2013) Revival of forgotten characters and modern imaging techniques help to produce a robust phylogeny of the Diplopoda (Arthropoda, Myriapoda). Arthr. Struct. and Devel. 43:63-75.

Blum, M., MacConnell, J., Brand, J., Duffield, R., Fales, H., (1973): Phenol and benzaldehyde in the defensive secretion of a strongylosomid millipede. Ann. Entomol. Soc. Amer. 66 (1): 235.

Blum, M., Woodring, J. (1962) Secretion of benzaldehyde and hydrogen cyanide by the millipede Pachydesmus crassicutis (Wood). Science 138:512-513.

Blum, M. (1981): Chemical defenses of arthropods. - Academic Press, New York, London etc. 1981: i-xii, 1-562.

Bodner, M., Raspotnig, G. (2012) Millipedes that smell like bugs: (E)-Alkenals in the defensive secretion of the julid diplopod Allajulus dicentrus. J. Chem. Ecol. 38:547-556.

Brandão, C. R. F., Diniz, J. L. M., Tomotake, E. M. (1991) Thaumatomyrmex strips millipeds for prey: a novel predatory behavior in ants and the first case of sympatry in the genus (Hymenoptera: Formicidae). Insectes Sociaux 38:335-344.

Brewer, M., Bond, J. (2013) Ordinal-level phylogenomics of the arthropod class Diplopoda (millipedes) based on an analysis of 221 nuclear protein-coding loci generated using next-generation sequence analyses. PLoS One 8:1-15.

Brown, W. (1992) Two new species of Gnamptogenys and an account of millipede predation by one of them. Psyche 99:275-289.

Brühl, C. Krell, F. (2003): Finding a rare resource: Bornean Scarabaeoidea (Coleoptera) attracted by defensive secretions of Diplopoda. Coleopt. Bull. 57 (1): $51-55$ - 
Buden, D., Attygalle, A., Wu, X. (2004): Distribution of the Chuuk Islands giant millipede, Acladocricus setigerus (Spirobolida: Rhinocricidae), and identification of its defensive compounds. Pac. Sci. 58 (4): 625-636 - (ISSN: 0030-8870).

Burrt, E. (1938) Irritant exudation from a millipede. Nature 142:796.

Burrt, W. (1947) Exudate from millipedes with particular reference to its injurious effects. Trop. Dis. Bull. 44:7-12.

Capone, F., Puopolo, M., Branchi, I., Alleva, E. (2002): A new easy, accessible and lowcost method for screening olfactory sensitivity in mice: Behavioural and nociceptive response in male and female $\mathrm{CD}-1$ mice upon exposure to millipede aversive odour. Brain Res. Bull. 58 (2): 193-202.

Capone, F., Venerosi, A., Puopolo, M., Alleva, E., Cirulli, F. (2005): Behavioral responses of $129 / \mathrm{Sv}, \mathrm{C} 57 \mathrm{BL} / 6 \mathrm{~J}$ and DBA/2J mice to a non-predator aversive olfactory stimulus. - Acta Neurobiol. Experim. (Warsaw) 65 (1): 29-34.

Carrel, J. (1984): Defensive secretion of the pill millipede Glomeric [Glomeris] marginata. 1. Fluid production and storage. J. Chem. Ecol. 10 (1): $41-51$ -

Carrel, J. , Britt, E. (2009) The whip scorpion, Mastigoproctus giganteus (Uropygi: Thelephonidae), preys on the chemically defended Florida scrub millipede Floridobolus penneri (Spirobolida: Floridobolidae). Fla. Entomol. 92:500-502.

Carrel, J., Doom, J., McCormick, J. (1985) Arborine and methaqualone are not sedative in the spider Lycosa ceratiola Gertsch \& Wallace. - J. Arachol. 13:269-271.

Carrel, J., Eisner, T. (1984): Spider sedation induced by defensive chemicals of millipede Glomeris marginata prey. - Proc. Nat. Acad. Sci. USA 81 (3): 806-810 - (ISSN: 00278424). 
Carroll, J., Kramer, M., Weldon, P., Robbins, R. (2005): Anointing chemicals and ectoparasites: Effects of benzoquinones from millipedes on the lone star tick, Amblyomma americanum. - J. Chem. Ecol. 31 (1): 63-75.

Casnati, G., Nencini, G., Quilco, A., Pavan, M., Ricca, A., Salvatori, T. (1963) The secretion of the myriapod Polydesmus collaris collaris (Koch). Experientia 19:409-411.

Causey, N., Tiemann, D. (1969) A revision of the bioluminescent millipedes of the genus Motyxia (Xystodesmidae, Polydesmida). Proc. Amer. Phil. Soc. 113:14-33.

Causey, N., Tiemann, D. (1970) The bioluminescent millipedes of the genus Motyxia (Xystodesmidae, Polydesmida). - Bull. Mus. Nat. d'Hist. Natur., ${ }^{\mathrm{e}}$ Series 41 (Suppl. 2):35-39.

Chamberlin, R. (1923) Results of the Bryant Walker Expeditions of the University of Michigan to Colombia, 1913, and British Guiana, 1914. The Diplopoda. Occ. Pap. Mus. Zool. Univ. Mich. 133:1-142.

Clark, V., Raxworthy, C., Rakotomalala, V., Sierwald, P., Fisher, B. (2005): Convergent evolution of chemical defense in poison frogs and arthropod prey between Madagascar and the Neotropics. Proc. Nat. Acad. Sci. USA 102 (33): 11617-11622.

Cloudsley-Thompson, J. (1949) The enemies of myriapods. Naturalist 831:137-141.

Conner, W., Jones, T., Eisner, T., Meinwald, J. (1977) Benzoyl cyanide in the defensive secretion of polydesmid millipeds. Experientia 33:206.

Conner, W., Alley, K., Barry, J., Harper, A. (2007) Has vertebrate chemesthesis been a selective agent in the evolution of arthropod chemical defenses? Biol. Bull. 213:267-273

Cook, O. (1900) Camphor secreted by an animal, Polyzonium. Science 12:516-521.

Coolidge, K. (1909) Secretion of hydrocyanic acid by Leptodesmus haydenianus Wood. Can. Entomol. 41: 104. 
Costa Neto, E. (2007) The perception of Diplopoda (Arthropoda, Myriapoda) by the inhabitants of the county of Pedra Branca, Santa Teresinha, Bahia, Brazil. Acta biol. Colombiana 12:123-134.

Curcic, B., M., Makarov, S., Tesevic, V., Jadranin, M., Vujisic, L. (2009). Identification of secretory compounds from the European callipodidan species Apfelbeckia insculpta. J. Chem. Ecol. 35:893-895.

Daly, J. (1995): The chemistry of poisons in amphibian skin. Proc. Nat. Acad. Sci. USA 92 (1): 9-13.

Daly, J., Garraffo, H., Jain, P., Spande, T., Snelling, R., Jaramillo, C., Rand, A. (2000) Arthropod-frog connection: decahydroquinoline and pyrrolizidine alkaloids common to microsympatric myrmicine ants and dendrobatid frogs. J. Chem. Ecol. 26:73-85.

Daly, J., Garraffo, H., Spande, T., Jaramillo, C., Rand, A. (1994) Dietary source for skin alkaloids of poison frogs (Dendrobatidae)? J. Chem. Ecol. 20:943-955.

Davenport, D., Wootton, M., Cushing, J. E. (1952) The biology of the Sierra luminous millipede, Luninodesmus sequoiae Loomis \& Davenport. Biol. Bull. 102:100-110.

Demange, J.-M. (1993) Les armes chimique des mille-pattes. Millepattia 2:29-61.

Deml, R.; Huth, Angela (2000): Benzoquinones and hydroquinones in defensive secretions of tropical millipedes. - Die Naturwissenschaften 87 (2): 80-82.

Disney, R., Ritchie, J. (1997) A new genus of Phoridae (Dipt.) that parasitizes an afrotropical millipede (Diplopoda, Odontopygidae). Entomol. Monthly Mag.133:151156. 
Duc Anh, N., Golovatch, S., Anichkin, A. (2005) The dragon millipedes in Vietnam (Polydesmida: Paradoxosomatidae, genus Desmoxytes Chamberlin, 1923) Arthrop. Sel. 14:251-257.

Duffey, S., Blum, M. (1977): Phenol and guaiacol biosynthesis, detoxication and function in a polydesmid millipede Oxidus gracilis. Insect Biochem. 7 (1): 57-66.

Duffey, S., Blum, M., Fales, H., Evans, S., Roncadori, R., Tiemann, D., Nakagawa, Y. (1977): Benzoyl cyanide and mandelonitrile benzoate in the defensive secretions of millipedes. J. Chem. Ecol. 3 (1): 101-113.

Duffey, S., Towers, G. (1978) On the biochemical basis of HCN production in the millipede Harpaphe haydeniana (Xystodesmidae: Polydesmida). Can. J. Zool. 56:7-16.

Duffey, S., Underhill, E., Towers, G. (1974): Intermediates in the biosynthesis of hydrogen cyanide and benzaldehyde by a polydesmid millipede Harpaphe haydeniana. Comp. Biochem. Physiol., Part B Comp. Biochem. 47 (4): 753-766.

Duffield, R., Blum, M., Brand, J. (1974) Guaicol in the defensive secretion of polydesmid millipedes. Ann. Entomol. Soc. Amer. 67:821-822.

Ehrlich, R., Dobkin, D., Wheye, D. (1986) The adaptive significance of anting. Auk 103:835.

Eisner, H., Eisner, T., Hurst, J. (1963) Hydrogen cyanide and benzaldehyde produced by millipedes. Chemistry and Industry 1963:124-125.

Eisner, H., Alsop, D., Eisner, T. (1967): Defense mechanisms of Arthropods. XX. Quantitative assessment of hydrogen cyanide production in two species of millipedes. Psyche 74 (2): 107-117. 
Eisner, T., Alsop, D., Hicks, K., Meinwald, J. (1978): Defensive secretions of millipedes. In: Bettini, Sergio (Ed) Arthropod Venoms. Springer-Verlag, (Handbook of Experimental Pharmacology 48): 41-72.

Eisner, T., Davis, J. A. (1967) Mongoose throwing and smashing millipedes. Science 155:577-579.

Eisner, T., Eisner, H. (1965) Mystery of a millipede. Nat. Hist. 74:30-37.

Eisner, T., Eisner, H., Hurst, J. J., Kafatos, F. C., Meinwald, J. (1963) Cyanogenic glandular apparatus of a millipede. Science 139:1218-1220.

Eisner, T., Eisner, M., Attygalle, A., Deyrup, M., Meinwald, J. (1998): Rendering the inedible edible: circumvention of a millipede's chemical defense by a predaceous beetle larva (Phengodidae). Proc. Nat. Acad. Sci. USA 95 (3): 1108-1113.

Eisner, T., Eisner, M., Deyrup, M. (1996): Millipede defense: use of detachable bristles to entangle ants. Proc. Nat. Acad. Sci. USA 93 (20): 10848-10851.

Eisner, T., Eisner, M., Siegler, M. (2005) Secret Weapons: Defenses of Insects, Spiders, Scorpions and Other Many-legged Creatures. Belknap Press, Cambridge (MA). 372 pp.

Eisner, T., Hurst, J., Keeton, W., Meinwald, Y. (1965) Defense mechanisms of arthropods. XVI. Para-benzoquinones in the secretion of spirostreptoid millipedes. Ann. Entomol. Soc. Amer. 58:247-248.

Eisner, T., Hurst, J., Meinwald, J. (1963): Defense mechanisms of Arthropods. XI. The structure, function, and phenolic secretions of the glands of a chordeumoid millipede and a carabid beetle. Psyche 70 (2): 94-116.

Eisner, T., Meinwald, J. (1966): Defensive secretions of arthropods. Science 153: 13411350. 
Eisner, T., Zahler, S., Carrel, J., Brown, D., Lones, G. (1970) Absence of antimicrobial substances in the egg capsules of millipedes. Nature 225:661.

Enghoff, H. (2011) Trans-segmental serial colour patterns in millipedes and their developmental interpretation (Diplopoda). Internat. J. of Myriapodol. 6:1-27.

Enghoff, H., Manno, N., Tchibozo, S., List, M., Schwarzinger, B., Schoefberger, W., Schwarzinger, C., Paoletti, M. (2014) Millipedes as food for humans: their nutritional and possible antimalarial value - a first report. Evidence-based Compl. Alt. Med. 2014:1-9.

Enghoff, H., Sutcharit, C., Panha, S. (2007) The shocking pink dragon millipede, Desmoxytes purpurosea, a colorful new species from Thailand (Diplopoda: Polydesmida: Paradoxosomatidae). Zootaxa 1563:31-36.

Ertek, M., Aslan, I., Yazgi, H., Torun, H., Ayyildiz, A., Tasyaran, M. (2004) Infestation of the human intestine by the millipede, Nopoiulus kochii. Med. Vet. Ent. 18:306-307.

Evans, M., Blower, J. (1973) A jumping millipede. Nature 246:427-428.

Fairhurst, C. (1993): Poisonous exudates of millipedes. Analyt. Proc. 30 (11): 429-430.

Forthman, M., and Weirauch, C. (2012) Toxic associations: a review of the predatory behaviors of millipede assassin bugs (Hemiptera: Reduiidae: Ectrichodiinae). Eur. J. Ent. 109:147-153.

Geiger, W. (1946) The mechanism of the antibacterial action of quinones and hydroquinones. Arch. Biochem. 11:23-32.

Gerdeman, B., Klompen, H., Tanigoshi, L. (2000): Insights into the biology of a mitemillipede association. In: Wytwer, J.; Golovatch, S. I. (Eds.): Progress in Studies on Myriapoda and Onychophora. Fragm. Faun., Warszawa, 43 (Supplement 2000), XIV+396 pp.: 223-227. 
Golovatch, S., Enghoff, H. (1994) Review of the dragon millipedes, genus Desmoxytes Chamberlin, 1923 (Diplopoda, Polydesmida, Paradoxosomatidae). Steenstrupia 20:4571.

Golovatch, S., Li, Y., Liu, W., Geoffroy, J.-J. (2012) Three new cavernicolous species of dragon millipedes, genus Desmoxytes Chamberlin, 1923, from southern China, with notes on a formal congener from the Philippines (Diplopoda, Polydesmida, Paradoxosomatidae). ZooKeys 185:1-17.

Haacker, Ulrich (1972): Zur Evolution einer defensiven Verhaltensweise bei Tausendfüßlern (Diplopoda: Julida: Spirostreptida). - Ab. Verh. Naturwiss. Ver. Hamburg (N.F.) 17: 117-124 - (ISSN: 0173-7481).

Haacker, U. (1974) Patterns of communication in courtship and mating behaviour of millipedes (Diplopoda). Symp. Zool. Soc. London 32:317-328.

Haddad, V., Cardoso, J. L. C., Rotta, O., Eterovic, A. (2000) Accidents provoked by millipede with dermatological manifestations. Dermatologia 75:471-474.

Hailey, Adrian; Coulson, Ian M.; Mwabvu, Tarombera (2001): Invertebrate prey and predatory behaviour of the omnivorous African tortoise Kinixys spekii. Afr. J. Ecol. 39 (1): 10-17.

Hall, F., Hollingsworth, R., Shankland, D. (1969). - Cyanide tolerance in millipedes: comparison of respiration in millipedes and insects. Ent. News 80:277-282.

Hall, F., Hollingsworth, R., Shankland, D. (1971) Cyanide tolerance in millipedes: the biochemical basis. Comp. Biochem. Physiol. 38B:723-737.

Halstead, B., Ryckman, R. (1949) Injurious effects from contacts with millipedes. Med. Arts Sci. 3:16-18. 
Haneveld, G. (1958) Eye lesions caused by the exudate of tropical millipedes. I. Report on a case. Trop. Geogr. Med. 10-165-167.

Haridrass, E., Ananthakrishnan, T. (1980): Models for the predatory behaviour of some reduviids from southern India (Insecta - Heteroptera - Reduviidae). Proc. Nat. Acad. Sci. India, Animal Sciences 89 (4): 387-402.

Hash, J. (2014) Species of Megaselia Rodani (Diptera: Phoridae) attracted to defensive compounds of cyanogenic millipedes (Diplopoda: Polydesmida). Proc. Ent. Soc. Washington 116: 243-282.

Hastings, J., Davenport, D. (1957) The luminescence of the millipede Luminodesmus sequoiae. Biol. Bull. 113:120-128.

Herbert, D. (2000) Dining on diplopods: remarkable feeding behavior in chlamydephorid slugs (Mollusca: Gastropoda). J. Zool., London 251:1-5.

Hoffman, R. (1971) Millipeds of the genus Brachoria in Virginia. Radford Rev. 25:8399.

Hoffman, R. (1979) Classification of the Diplopoda. Mus. d'Hist. Nat. Gèneve. 237 pp.

Hopkin, S., Read, H. (1992) The Biology of Millipedes. Oxford University Press, Oxford. 233 pp.

Hudson, B., Parsons, G. (1997): Giant millipede "burns" and the eye. Trans. Roy. Soc. Trop. Med. Hyg. 91 (2): 183-185.

Huth, A. (2000): Defensive secretions of millipedes: more than just a product of melting point decrease? In: Wytwer, J.; Golovatch, S. I. (Eds.): Progress in Studies on Myriapoda and Onychophora. Fragm. Faun., Warszawa, 43 (Supplement 2000), XIV+396 pp.: 191-200. 
Ito, F. (1998) Colony composition and specialized predation on millipedes in the enigmatic ponerine ant genus Probolomyrmex (Hymenoptera, Formicidae). Insect. Soc. 45:79-83.

Kikunaga, T., Kinjyo, H., Kuniyoshi, M. (1993) Studies on the constituents of smells from some Okinawan local millipedes. Bull. Coll. Sci., Univ. Ryukyus 56:91-112 (In Japanese with English abstract).

Kinkel, H. (1955) Zur Biologie und Ökologie des getüptelten Tausendfusser Blaniulus guttulatus Gerv. Mitt. Deutsch. Gesell. Ang. Ent. 37:401-436.

Kluge, A., Eisner, T. (1971) Defense mechanisms of arthropods. XXVIII. A quinone and a phenol in the defensive secretion of a parajulid milliped. Ann. Ent. Soc. Amer. 64:314315

Kon, M., Ochi, T., Nabhitabata, J., Araya, K., Matsui, M. (1998): Necrophagous scarab beetles (Coleoptera, Scarabaeidae, Onthophagus) attracted to a diplopod copulating pair (Diplopoda) in Thailand. Elytra 26 (2): 347-349.

Krell, F.-T. (1999): Southern African dung beetles (Coleoptera: Scarabaeidae) attracted by defensive secretions of Diplopoda. Afr. Ent. 7: 287-288.

Krell, F-T. (2004): East African dung beetles (Scarabaeidae) attracted by defensive secretions of millipedes. - J. East Afr. Nat. Hist. 93 (1-2): 69-73.

Krell, F.-T., Schmitt, T., Linsenmair, K. (1997): Diplopod defensive secretions as attractants for necrophagous scarab beetles (Diplopoda; Insecta, Coleoptera, Scarabaeidae). In: Enghoff, H. (Ed.): Many-legged animals - A collection of papers on Myriapoda and Onychophora. Ent. Scand., Suppl. 51, 329 pp.: 281-286.

Kuwahara, Y., Mori, N., Tanabe, T. (2007) Detection of a neotropical frog alkaloid spiropyrrolizidine 236 from a Japanese polyzoniid millipede Kiusiozonium okai as a 
major defense component together with polyzonimine and nitropolyzonimine. - Japan. J. Environ. Ent. Zool. 18:91-96.

Kuwahara, Y., Omura, H., Tanabe, T. (2002): 2-Nitroethenylbezenes as natural products in millipede defense secretions. Die Naturwissenschaften 89 (7): 308-310.

Kuwahara, Y., Shimizu, N., Tanabe, T. (2011) Release of hydrogen cyanide via a postsecretion Schotten-Baumann reaction in defensive fluids of polydesmoid millipedes. J. Chem. Ecol. 37:232-238.

LaBonte, J. (1985) Feeding behavior of the carabid beetle, Promecognathus. Bull. Oregon Ent. Soc. 86: 681-682.

Larsen, T. H., Lopera, A., Forsyth, A., Génier, F. (2008) From coprophagy to predation: a dung beetle that kills millipedes. Biol. Lett. (Animal Behaviour) 13:42-45.

Liu, W., Golovatch, S., Tian, M. (2014) A review of the dragon millipede genus Desmoxytes Chamberlin 1923 in China, with descriptions of four new species (Diplopoda, Polydesmida, Paradoxosomatidae). ZooKeys 448:9-26.

Leonard, W., Stebbins, R. (1999): Observations of antipredator tactics of the sharp-tailed snake (Contia tenuis). Northw. Nat. 80 (2): 74.

Levi, H. W. (1965) An unusual case of mimicry. Evolution 19:261-262.

Loomis, H. (1936) The millipedes of Hispaniola, with descriptions of a new family, new genera, and new species. Bull. Mus. Comp. Zool. 80: 151-262.

Loomis, H. (1959) New myrmecophilous millipeds from Barro Colorado Island, Canal Zone, and Mexico. J. Kansas Ent. Soc. 32:1-7. 
Mallet, J., Joron, M. (1999). Evolution of diversity in warning color and mimicry: polymorphisms, shifting balance, and speciation. Ann. Rev. Ecol. Syst., 201-233.

Makarov, S. E., Curcic, B. P. M., Tesevic, V. V. (2010) Defensive secretions in three species of polydesmids (Diplopoda, Polydesmida, Polydesmidae). J. Chem. Ecol. 36:978-982.

Makarov, W., Dimkic, I., Antic, D., Vijusic, L., Stevic, T., Mitic, B., Tomicem, V., Ilic, B., Curcic, B., Stankovic, S. (2014) Pachyiulus hungaricus (Karsch, 1881)—a modelsystem for semiochemical analysis and antimicrobial testing. In Tuf, I. H. \& Tajovsky, K. (eds.) $16^{\text {th }}$ International Congress of Myriapodology, Book of Abstracts (p. 51) Olomouc: Institute of Soil Biology, BC ASCR \& Faculty of Science, Palacky University.

Marek, P., Bond, J. (2009) A Müllerian mimicry ring in Appalachian millipedes. - Proc. Nat. Acad. Sci. USA 106:9755-9760.

Marek, P., Papaj, D., Yeager, J., Molina, S., Moore, W. (2011) Bioluminscent aposematism in millipedes. Curr. Biol. 21:680-681.

Marek, P., Shear, W., Bond, J. (2012) A redescription of the leggiest animal, the millipede Illacme plenipes, with notes on its natural history and biogeography (Diplopoda, Siphonophorida, Siphnonrinidae). ZooKeys 241:77-112.

Martínez-Torres, S., Flórez Daza, A., Linares-Castillo, E. (2011) Meeting between kingdoms: discovery of a close association between Diplopoda and Bryophyta in a transitional Andean-Pacific forest in Colombia. Myriapodology 6:29-36.

Meinwald, J., Smolanoff, J., McPhall, A., Miller, R. (1975): Nitropolyzonamine: A spirocyclic compound from the defensive glands of a milliped (Polyzonium rosalbum). Tetrahadron Lett. 28: 2367-2370.

Meinwald, Y. C., Meinwald, J., Eisner, T. (1966) 1,2-dialkyl-4(3H)-quinazolinones in the defensive secretions of a millipede (Glomeris marginata). Science 154:390-391. 
Minch, E. (1978): The effectiveness of chemical defences against predation by the tarantula Aphonopelma chalcodes Chamberlin. - Bull. Brit. Arachnol. Soc. 4 (6): 275278 (ISSN: 0524-4994).

Monro, A., Chadha, M., Meinwald, J., Eisner, T. (1962) Defense mechanisms of arthropods. VI. Para-benzoquinones in the secretion of five species of millipedes. Ann. Ent. Soc. Amer. 55:261-262.

Mori, K. Takagi, Y. (2000): Enantioselective synthesis of polyzonimine and nitropolyzonamine, spirocyclic compounds from the defensive glands of a millipede, Polyzonium rosalbum. Tetrahedron Lett. 41 (34): 6623-6625.

Mori, N., Kuwahara, Y., Yoshida T., Nishida, R. (1994): Identification of Benzaldehyde, Phenol and Mandelonitrile from Epanerchodus japonicus Carl (Polydesmide:

Polydesmidae) as Possible Defense Substances. Appl. Ent. Zool. 29 (4): 517-522 (ISSN: 0003-6862).

Mori, N., Kuwahara, Y., Yoshida, T., Nishida, R. (1995): Major defensive cyanogen from Parafontaria laminata armigera Verhoeff (Xystodesmidae: Polydesmida). Appl. Ent. Zool. 30 (1): 197-202.

Monteiro, H. (1961) Constituents of the secretion of Orthomorpha coarctata Schubart. An. Asoc. Bras. Quim. 20:29-31.

Mousstaché, H., Lopez Cuadra, J., Ramos, P., Perissé, A., Salles, C., Loureiros, E. (1969) Chemistry and pharmacology of the venomous secretion of Rhinocricus varians. Rev. Bras. Biol. 29:25-34.

Mowlavi, Gh., Naddaf, S., Resaeian, M., Najafi, N., Lucio-Forester, A., Bowman, D. (2009) Apparent pseudoparasitism of the alimentary canal of a 5-year-old child by the millipede Brachyiulus lusitanius (Diplopoda: Julidae). Parasite 16:161-163.

Nishio, N., Eguchi, N., Fujiyama, S. (1995): On the amounts of cyanides contained in an adult of Parafontaria laminata armigera (Verhoeff), and Epanerchodus orientalis (Attems). Edaphologia 53: 25-29. 
Noguchi, S., Mori, N., Higa, Y., Kuwahara, Y. (1997a): Identification of mandelonitrile as a major secretory compound from Chamberliniulus hualienensis Wang. Japan. J. of Env. Ent. Zool. 8:208-214.

Noguchi, S., Mori, N., Higa, Y., Kuwahara, Y. (1997b): Identification of Nedyopus patrioticus patrioticus (Attems, 1898) (Polydesmida: Paradoxosomatidae) secretions as possible defense substances. Appl. Ent. Zool. 32 (3): 447-452.

Olivieri, N., Capone, F., Puopolo, M., Santucci, D., Alleva, E. (2001) Response of CD-1 mice to the chemical defence of a common arthropod (Ommatoiulus sabulosus). Physiol. Behav. 74 (3): 305-311.

Omura, H., Kuwahara, Y., Tanabe, T. (2002a): 1-octen-3-ol together with geosmin: New secretion compounds from a polydesmid millipede, Niponia nodulosa. J. Chem. Ecol. 28 (12): 2601-2612.

Omura, H., Kuwahara, Y., Tanabe, T. (2002b): Species-specific chemical compositions of defense secretions from Parafontaria tonominea Attems and Riukiaria semicircularis semicircularis Takakuwa (Polydesmida: Xystodesmidae). Appl. Ent. Zool. 37 (1): 73-78.

Pallares, E. S. (1946) Note on the poison produced by the Polydesmus (Fontaria) vicinus, L. Arch. Biochem. 9:105-108.

Parkes, K., Weldon, P., Hoffman, R. (2003) Polydesmidan millipede used in selfanointing by a strong-billed woodcreeper (Xiphocolaptes promeropirhyncus) from Belize. Ornitol. Neotrop. 14:285-286.

Percy, J., Weatherston, J. (1971): Studies of physiologically active arthropod secretions Part 5: histological studies of the defense mechanism of Narceus annularis (Diplopoda Spirobolida). Can. J. Zool. 49 (2): 278-279.

Perissé, A., Salles, C. (1970) Estudo químico de Diplopoda Brasilieros. III. Collostreptus fulvus (Schubart, 1960). Act. Soc. Biol. Rio de Janeiro 13:95-99. 
Perrisé, A. C. M., Salles, C. A., Mousstaché, H. (1968) Estudo químico de Diplopoda Brasilieros II. Spirostrophus naresi (Pocock). Act. Soc. Biol. Rio de Janeiro 12:155156.

Peterson, S. C. (1986) Breakdown products of cyanogenesis: repellency and toxicity to predatory ants. Naturwissenschaften 73:627-628.

Radford, A. J. (1975) Millipede burns in man. Trop. Geogr. Med. 27:279-287.

Raspotnig, G., Bodner, M. (2014) Beyond benzoquinones: chemical diversity of defensive secretions in the Julida (Diplopoda). In: Tuf, I., Tajovsk'y, K. (eds.), $16^{\text {th }}$ International Congress of Myriapodology Book of Abstracts. Institute of Soil Biology, Palacky University, Olomouc, Czech Republic: 72.

Rettenmeyer, C. (1962) The behavior of millipeds found with neotropical army ants. J. Kansas Ent. Soc. 35:377-384.

Roncadori, R., Duffey, S., Blum, M. (1985): Antifungal activity of defensive secretions of certain millipedes. Mycologia 77 (2): 185-191.

Röper, H., Heyns, K. (1977) Spurenanalytik von p-Benzchinon und HydrochinonDerivaten mit Gaschromatographie und Gaschromatographie/Massenspektrometrie Identifizierung von Wehrsekret-Komponenten europäischer Juliden. Z. Natur., Section C, Journal of Biosciences 32 (1-2): 61-66.

Röper, H. (1978) Ergebnisse chemisch-analytischer Untersuchungen der Wehrsekrete von Spirostreptiden, Spiroboliden und Juliden (Diplopoda), von Peripatopsis (Onychophora) und von Polyzonium (Diplopoda, Colobognatha). Abh. Verhand. Naturwiss. Ver. in Hamburg 21-22: 353.

Ruxton, G., Sherratt, T., Speed, M. (2004) Avoiding Attack: The Evolutionary Ecology of Crypsis, Warning Signals and Mimicry. Oxford University Press, 264 pp. 
Santori, R. (1998) Discrimination of millipedes by the opossum Didelphis albiventris (Marsupialia, Didelphidae). J. Adv. Zool. 19 (2): 118-119.

Saporito, R., Donnelly, M., Hoffman, R., Garraffo, H., Daly, J. (2003) A siphonotid millipede (Rhinotus) as the source of spiropyrrolizidine oximes of dendrobatid frogs. J. Chem. Ecol. 29:2781-2786.

Saporito, R., Donnelly, M., Garraffo, H., Spande, T., Daly, J. (2006) Geographic and seasonal variation in alkaloid-based chemical defenses of Dendrobates pumilio from Bocas del Toro, Panama. J. Chem. Ecol. 32:795-814.

Saporito, R., Spande, T., Garraffo, H., Donnelly, M. (2009) Arthropod alkaloids in poison frogs: a review of the "dietary hypothesis." Heterocycles 79:277-297.

Savi, P. (1823) Bemerkungen uber Julus communis. Okens Isis 12-13:214-222.

Sazima, I. (2009) Anting behaviour with millipedes by the dendrocolaptid bird Xiphocolaptus albicollis in Brazil. Biota Neotr. 9:249-252.

Schildknecht, H., Maschwitz, U., Wenneis, W. (1966) Neue Stoffe aus dem Wehrsekret der diplopodengattung Glomeris. Uber Arthropoden-Abwehrstoffe. XXIV. Naturwissenschaften 54:196-197.

Schildknecht, H., Weiss, K., (1961) Chinone als actives Prinzip de Abwehrstoffe von Diplopoden. Z. Natur. 16b:810-816.

Schildknechte, H., Wenneis, W. (1967a) Über Arthropoden-Abwehrstoffe. XX. Structuraufklärung des Glomerins. Z. Natur. 21b:552-556.

Schilknechte, H., Wenneis, W. (1967b) Über Arthropoden-Abwehrstoffe. XXV. 
Anthranilsäure als Precursor der Arthropoden-alkaloide Glomerin und Homoglomerin. Tetrahedron Lett. 1967:1815-1818.

Schildknechte, H., Wenneis, W., Weis, K., Maschwitz, U. (1966) Glomerin, ein neues Arthropoden-alkaloid. - Z. Natur. 21b:121-127.

Schmalfuss, H. (2013) Revision of the Armadillidium klugii-group (Isopoda: Oniscidea). Stuttgarter Beitr. Naturk. A, Neue Serie 6: 1-12.

Schmitt, T., Krell, F.-T., Linsenmair, K. (2004): Quinone mixture as attractant for necrophagous dung beetles specialized on dead millipedes. J. Chem. Ecol. 30 (4): 731740 .

Sekulic, T., Vujisic, Lj., Curcic, B., Mandic, B., Antic, D., Trifunovic, S., Godovac, D., Vajs, V., Tomic, V., Makarov, S. (2014) Quinones and non-quinones from the defensive secretion of Unciger transsilvanicus (Verhoeff, 1899) (Diplopoda, Julida, Julidae), from Serbia. Arch. Biol. Sci., Belgrade 66:385-390.

Shear, W. (1982) Millipeds (Diplopoda) from caves in Mexico and Central America. IV. New species and records of Glomeridae, Cleidogonidae, Trichopetalidae, Fuhrmannodesmidae, and Sphaeriodesmidae. Texas Mem. Mus. Bull. 28:145-160.

Shear, W. (1994) Myriapodous arthropods from the Visean of East Kirkton, West Lothian, Scotland. Trans. Roy. Soc. Edinburgh, Earth Sci. 84:309-316.

Shear, W. (2008) Spinnerets in the milliped order Polydesmida, and the phylogenetic significance of spinnerets in millipeds (Diplopoda). Int. J. Myriapodol. 2:123-146.

Shear, W. (2011) "Class Diplopoda de Blainville in Gervais, 1844. In: Zhang, Z.-Q. (Ed.) Animal biodiversity: An outline of higher-level classification and survey of taxonomic richness. Magnolia Press, Auckland.

Shear, W., Edgecombe, G. (2010) The geological record and phylogeny of the Myriapoda. Arthr. Struc. Dev. 39:174-190. 
Shear, W., Jones, T., Miras, H. (2007) A possible phylogenetic signal in milliped chemical defenses: the polydesmidan milliped Leonardesmus injucundus Shelley \& Shear secretes $p$-cresol and lacks a cyanogenic apparatus (Diplopoda, Polydesmida, Nearctodesmidae). - Biochem. Syst. Ecol. 35:838-842.

Shear, W., Jones, T., Wesener, T. (2011) Glomerin and homoglomerin from the North American pill millipede Onomeris sinuata (Loomis, 1943) (Diplopoda, Pentazonia, Glomeridae). Int. J. Myriapodpl. 4:1-10.

Shear, W., Krejca, J. (2011) Cave millipeds of the United States. IX. A new species of the genus Taiyutyla (Diplopoda, Chordeumatida, Conotylidae) from caves in Sequoia and Yosemite National Parks, California, USA. J. Cave Karst Stud. 73:93-98.

Shear, W., McPherson, I., Jones, T., Loria, S., Zigler, K. (2010) Chemical defense of a troglobiont millipede, Tetracion jonesi Hoffman (Callipodida, Abacionidae). Int. J. Myriapodol. 3:253-158.

Shear, W., Shelley, R., Heatwole, H. (2003) Occurrence of the milliped Sinocallipus simplipodicus Zhang, 1993 in Laos, with reviews of the Southeast Asian and global callipodidan faunas, and remarks on the phylogenetic position of order (Callipodida: Sinocallipodidea: Sinocallipodidae). Zootaxa 365:1-20.

Shelley, R. M. (1997) A re-evaluation of the milliped genus Motyxia Chamberlin, with a rediagnosis of the tribe Xystocheirini and remarks on the bioluminescence. Insecta Mundi 11::331-351.

Shimizu, N., Kuwahara, Y., Yakamaru, R., Tanabe, T. (2012) n-hexyl laurate and fourteen related fatty-acid esters: new secretory compounds from the julid millipede, Anaulaciulus sp. J. Chem. Ecol. 38:23-28.

Shimomura, O. (1984) Porphyrin chromophore in Luminodesmus photoprotein. Comp. Biochem. Physiol. B 79:565-567.

Shpall, S.; Frieden, I. (1991): Mahogany discoloration of the skin due to the defensive secretion of a millipede. Ped. Derm. 8 (1): 25-27. 
Sierwald, P., Bond, J. (2007) Current status of the myriapod Class Diplopoda (millipedes): taxonomic diversity and phylogeny. Ann. Rev. Ent. 52:401-420.

Sierwald, P., Shear, W., Shelley, R., Bond, J. (2003) Millipede phylogeny revisited in the light of the enigmatic order Siphoniulida. J. Zool. Syst. Evol. Res. 41:87-99.

Simmons, K. (1966) Anting and the problem of self-stimulation. J. Zool. (London) 149:145-162.

Slay, M., Fong, D., Kottmyer, M. (2009) Meta ovalis (Araneae: Tetragnathidae) observed preying on a troglobitic milliped, Causeyella (Chordeumatida: Trichopetalidae). Speleobiology Notes 1: 3-5.

Smolanoff, J., Demange, J. M., Eisner, T., Meinwald, J. (1975) 1,4-benzoquinones in African millipedes. Psyche 82:78-80.

Smolanoff, J., Kluge, A., Meinwald, J., McPhail, A., Miller, R. W., Hicks, K., Eisner, T. (1975) Polyzonimine: a novel terpenoid insect repellent produced by a millipede. Science 188:734-736.

Stebbins, R. C. (1944) Lizards killed by a millipede. Amer. Midl. Nat. 32:777-778.

Taira, J.,; Arakaki, K. (2002) Secretions of Chamberlinius hualienensis Wang (Polydesmida: Paradoxosomatidae) during the reproductive migration stage. Appl. Ent. Zool. 37 (4): 621-624.

Taira, J., Nakamura, K., Higa, Y. (2003) Identification of secretory compounds from the millipede, Oxidus gracilis C.L. Koch (Polydesmida:Paradoxosomatidae) and their variation in different habitats. Appl. Ent. Zool. 38:401-404.

Tichy, H. (1974) Über den Feinbau der Wehrdrüsen von Tausendfüsslern. Zool. Anz. 192: 289-302. 
Tiemann, D. (1967) Observations on the natural history of the western banded glowworm, Zarhipis integripennis (Le Conte) (Coleoptera: Phengodidae). Proc. California Acad. Sci. 35:235-264.

Towers, G., Duffey, S., Siegel, S. (1972): Defensive secretion biosynthesis of hydrogen cyanide and benzaldehyde from phenylalanine by a millipede. Can. J. Zool. 50 (7): 10471050.

Trave, R., Garanti, L., Pavan, M. (1959) Ricerche sulla natura chimica de veleno del miriapode Archiulus (Schizophyllum) sabulosus L. Chem. Ind. 41:19-29.

Ubik, K., Krecek, J., Vasickova, S. (1982): Defensive secretion of the Cuban millipede Rhinocricus duvernoyi (Diploda, Spirobolida). Acta Entomol. Bohemoslovaca 79 (6): 468-469.

Urzua, A.; Silva, F. (1982): Componentes quimicos de las secreciones defensivas de miriapodos-diplopodos del genero Autostreptus, Silvestri, 1905 (SpirostreptidaSpirostreptidae). An. Mus. Hist. Nat. Valparaiso 14: 271-273.

Vahtera, V., Edgecombe, G. (2014) First molecular data and the phylogenetic position of the millipede-like centipede Edentostoma octosulcatum Tömösváry 1882 (Chilopoda: Scolopendromorpha: Scolopendridae). PLOSone e112461, 9:1-8

Valderrama, X., Robinson, J., Attygalle, A., Eisner, T. (2000): Seasonal anointment with millipedes in a wild primate: a chemical defense against insects? J. Chem. Ecol. 26 (12): 2781-2790.

Vitt, L. J. (1992) Lizard mimics millipede. Nat. Geogr. Res. Expl. 8:76-95.

Vujisic, L., Antic, D., Vuckovic, I., Sekulic, T., Tomic, V., Mandic, B., Tesevic, V., Curcic, B., Vajs, V., Makarov, S. (2014) Chemical defense in millipedes (Myriapoda, Diplopoda): Do representatives of the family Blaniulidae belong to the 'quinone' clade? Chem. Biodiv. 11:483-490. 
Weatherston, J., Percy, J. (1969) Studies of physiologically active arthropod secretions. III. Chemical, morphological, and histological studies of the defence mechanism of Uroblaniulus canadensis (Say) (Diplopoda: Julida). Can, J. of Zool. 47:1389-1394.

Weatherston, J., Tyrrell, D., Percy, J. (1971): Long chain alcohol acetates in the defensive secretion of the millipede Blaniulus guttulatus. Chem. Phys. Lipids 7 (1-2): 98-100.

Weatherston, J.; Gardiner, E. (1973): The defensive secretion of a polydesmoid millipede (Diplopoda). Can. Ent. 105 (10): 1375-137.

Weldon, P., Aldrich, J., Klun, J., Oliver, J., Debboun, M. (2003) Benzoquinones from millipedes deter mosquitos and elicit self-anointing in capuchin monkeys. Naturwissenschaften 90:301-304.

Weldon, P., Cranmore, C., Chatfield, J. (2006) Prey-rolling behavior of coatis (Nasua sp.) is elicited by benzoquinones from millipedes. Naturwissenschaften 93:14-16.

Wesener, T. (2014) Redescription of 'Polyzonium' malagassum, a new synonym of Rhinotus purpureus (Pocockm 1894) with notes about the occurrence of the order Polyzoniida on Madagascar (Diplopoda). Zootaxa 3790:587-594.

Wesener, T., Enhoff, H., Sierwald, P. (2009) Review of the Spirobolida on Madagascar, with descriptions of twelve new genera, including three genera of 'fire millipedes' (Diplopoda). ZooKeys 19:1-128.

Wheeler, J., Meinwald, J., Hurst, J., Eisner, T. (1964) Trans-2-dodecenal and 2methyl,1,4-quinone produced by a millipede. Science 144:540-541.

Wheeler, W. (1890) Hydrocyanic acid secreted by Polydesmus virginianus Drury. Psyche [vol.?]:442. 
Whitehead, D. , Shelley, R. (1992) Mimicry among aposematic Appalachian xystodesmid millipedes (Polydesmida: Xystodesmidae). Proc. Ent. Soc. Washington 94:177-188.

Williams, L., Singh, P., Williams L. (1997): Biology and biological action of the defensive secretion from a Jamaican millipede. Die Naturwissenschaften 84 (4): 143144.

Wilson, H. (2006) Juliformian millipedes from the Lower Devonian of Euramerica: implications for the timing of millipede cladogenesis in the Paleozoic. J. Paleo. 80:638-649.

Wood, W. (1974): Toluquinone and 2 methoxy-3-methylbenzoquinone from the defensive secretions of 3 African millipedes. Ann. Ent. Soc. Amer. 67 (6): 988-989.

Wood, W., Shepherd, J., Chong, B., Meinwald, J. (1975) Ubiquinone-O in the defensive spray of an African millipede. Nature 253:625-626.

Wood, W., Hanke, F., Kubo, I., Carroll, J., Crews, P. (2000): Buzonamine, a new alkaloid from the defensive secretion of the millipede, Buzonium crassipes. Biochem. Syst. Ecol. 28 (4): 305-312.

Wood, W., Soerensen, P. (2005) The defensive secretion of the millipede, Nearctodesmus salix (Polydesmida: Nearctodesmidae). Biochem. Syst. Ecol. 33:10771079.

Woodring, J., Blum, M. (1963) The anatomy and physiology of the repugnatorial glands of Pachydesmus crassicutus. Ann. Ent. Soc. Amer. 56:448-453.

Woodring, J., Blum, M. (1965) The anatomy, physiology and comparative aspects of the repugnatorial glands of Orthocricus arboreus (Diplopoda: Spirobolidae). J. Morph. 116:99-108. 
Wu, X., Buden, D., Attygalle, A. (2007) Hydroquinones from defensive secretion of a giant Pacific millipede, Acladocricus setigerus (Diplopoda: Spirobolida). Chemoecology 17:131-138.

Wüest, J. (2002): La defense par les poils. Bull. Romand d'Entomol. 20 (1): 41-44.

Youngsteadt, N. W. (2008) Laboratory observations on the behavior of two troglobitic millipede species in the genus Causeyella (Chordeumatida: Trichopetalidae) from the southern Ozarks. Trans. Kansas Acad. Sci. 111:136-140.

Zagrobelny, M., Bak, S., Møller, B. L. (2008) Cyanogenesis in plants and arthropods. Phytochemistry 69:1457-1468.

Zito, M., Evans, S., Weldon, P. (2002) Owl monkeys (Aotus sp.) self-anoint with plants and millipedes. Fol. Primat. 74:159-161. 


\section{Figure and Table Captions}

Table 1. Species of millipedes for which at least some components of their chemical defenses have been identified. Under "Species," names in parentheses are synonyms under which the original research may have been published. "Chemical components" in bold type are deemed unusual for the higher taxon in which the species has been placed.

Table 2. Abstract and summary of Table 1 at the family level. See text for further explanation.

Fig. 1. Structural formulae of some defensive compounds produced by millipedes. A. Hydrogen cyanide. B. Trans-2-dodecanol. C. Benzaldehyde. D. Mandelonitrile. E. Benzoyl cyanide. F. Phenol. G. o-cresol. H. $p$-cresol. I. Guaiacol. J. 1,4benzoquinone. K. Glomerin. L. Homoglomerin. M. Polyzonimine. N. Nitropolyzonamine. Structures redrawn from Eisner et al (1978). For additional formulae, see Fig. 2.

Fig. 2. Structural formulae of some benzoquinones and hydroquinones found in the defensive secretions of Telodeinopus aouii and an unidentified harpagophorid species. Arrows represent a possible metabolic sequence beginning with hydroquinone (9). 1. $p$ benzoquinone. 2. Toluquinone. 3. 2-methoxy-3-methylbenzoquinone. 4. 2ethylbenzoquinone. 5. 2-methoxybenzoquinone. 6. 2,3-dimethoxybenzoquinone. 7. 2,3dimethoxy-5-methylbenzoquinone. 8. Naphthoquinone. 9. Hydroquinone. 10. Toluhydroquinone. 11. 2-methoxy-3-methylhydroquinone. 12. 3methoxyhydroquinone. 13. 2,3-dimethoxyhydroquinone. 14. 2,3-dimethoxy-5methylhydroquinone. 15. 2-ethyl-hydroquinone. Structures redrawn from Deml and Huth (2000).

Figs. 3-5. Structure of defensive glands. Fig. 3. Type 1 defensive glands of Glomeris marginata. A. Distribution of glands in the intact animal; eight glands open through single mid-dorsal pores beginning in the intersegmental membrane just anterior to diplosegment 4. B. Pore and muscular bulb. C. Glands are located in the segment anterior to the pore opening; G. marginata shown defensively enrolled. D. One arm of a gland, showing loose investment of muscle fibers. Redrawn from Eisner et al (1978).

Fig. 4. Type 2 defensive gland of a spirostreptid millipede; glands open laterally on the left and right sides of a trunk ring. See text for description. Redrawn from Barth (1967). Fig. 5. Type 3 defensive gland of a xystodesmid millipede; glands open laterally on the left and right sides of only some of the trunk rings. Precursor from the reservoir is admitted to the vestibule by a valve between them; in the vestibule the precursor is enzymatically broken down to release HCN. Photograph courtesy of Paul Marek. 
Figs. 6-8. Synthesis of some millipede defensive compounds. Fig. 6. Synthesis of homoglomerin from anthranilic acid. Homoglomerin was subsequently converted to methylanthranilic acid, demonstrating that the labeled carbon maintained the same position. Redrawn from Schildknecht and Wenneis (1967). Fig. 7. Pathway proposed for the synthesis of mandelonitrile and benzaldehyde in the xystodesmid milliped Harpaphe haydeniana. The last step takes place in the gland vestibule and results in the release of hydrogen cyanide. Redrawn from Duffey and Towers (1977). Fig. 8. In vitro synthesis of \pm polyzonimine by Smolanoff et al (1975). A. 2,2-dimethyl-7-oxabicycloheptane. B. 2,2-dimethylcyclopentanecarboxaldehyde. C. Enamine of B. D. Nitroaldehyde of C. E. Reduction product of D. F. \pm Polyzonimine. Redrawn from Smolanoff et al (1975).

Figs. 9-15. Aposematic coloration in millipedes. Fig. 9. Aulacobolus rubropunctatus, "Peppermint millipede," a spirobolidan from South Africa. Fig. 10. Auturus leachii, eastern North America (Polydesmida, Euryuridae). Photo courtesy Alan Cressler. Fig. 11. An unidentified chelodesmid from Brazil (Polydesmida, Chelodesmidae). Photo couresty Joseph Warfel. Fig. 12. Aphistogoniulus erythrocephalus, from Madagascar (Spirobolida, Spirobolidae). Fig. 13. An unidentified paradoxosomatid from southeast Asia (Polydesmida, Paradoxosomatidae). Fig. 14. Strongylodesmus sp., from Mexico; blue is unusual as an aposematic signal, but the signal may reside in the contrast with the white paranota (Polydesmida, Rhachodesmidae). Photo by George Grail. Fig. 15. Zoosphaerium aureum, A sphaerotheriid from Madagascar; sphaerotheriids have no chemical defenses, so this species may be mimicking a syntopic spirobolid, such as shown in Fig. 12.

Fig. 16. Motyxia tiemanni, illuminated by its own bioluminescence. Photo by Paul Marek.

Fig. 17. Müllerian mimicry in a clade of Appalachian xystodesmid millipedes. At each of seven sites, Apheloria sp. (an undescribed species) serves as a model for one or more other chemically defended xystodesmids. The models and mimics are almost indistinguishable in the field, but may be clearly separated by reference to the male genitalia. Brachoria dentata co-occurs with Apheloria sp. at sites 3, 26 and 28; its pattern closely tracks the variation in Apheloria sp. Similarly, at sites 4 and 5, Brachoria mendota shows two entirely distinct color patterns, resembling Apheloria sp. rather than conspecifics at the other site. Figure courtesy of Paul Marek. 
Figs. 18, 19. Specialist predators on millipedes. Fig. 18. A Phengodes sp. larva (Coleoptera, Phengodidae) feeding on the spirobolid millipede Narceus gordanus in Florida, USA. Photo by Alan Cressler. Fig. 19. An assassin bug (Reduviidae, Etrichodiinae) attacks a spirobolid millipede in South Africa.

Figs. 20, 21. Some subsocial behavior in millipedes may be mediated by allomones acting as pheromones. Fig. 20. Brachycybe lecontei (Platydesmidae, Andrognathidae) are often found in central and southern North America in aggregations including both sexes and all instars. Photo by Jasper Nance. Fig. 21. A migratory swarm of juveniles of an unidentified paradoxosomatid in Nepal.

Figs. 22-25. Other defense mechanisms of millipedes. Fig. 22. A sphaerotheriid (Sphaerotheriida, Sphaerotheriidae) from Madagascar is capable of completely rolling up into a sphere with head, legs and antennae inside, protected by hard, smooth cuticle. Fig. 23. Desmoxytes sp. (Polydesmida, Paradoxosomatidae) from southeast Asia are protected by hard, branched spines projecting from the dorsum, as well as the ability to produce HCN and benzaldehyde. Photo courtesy of Somsak Panha. Fig. 24. Polyxenus fasciculatus (Polyxenida, Polyxenidae) has soft cuticle and no chemical defense, but the tufts of hooked setae at the posterior end entangle and disable predators such as ants. Fig. 25. Taiyutyla loftinae (Chordeumatida, Conotylidae) has six long setae on each ring, which carry sticky droplets. The droplets may deter predators and parasites. Photo by Jean Krejca.

Fig. 26. Phylogenetic tree of millipede orders (except for Siphoniulida) as constructed by Blanke and Wesener (2013) based on morphological characters. Broad classes of defensive compounds are mapped on the tree as follows: $\mathbf{1}$, glomerin and homoglomerin (quinazolinone alkaloids). 2, polyzonimine, nitropolyzonamine, buzonamine and related compounds. 3, pinenes. 4, hydro- and benzoquinones. 5. phenolic compounds and derivatives (phenol, cresol, guaiacol, etc.). 6, cyanogenesis. 7, $p$-cresol. Numbers in parentheses indicate hypotheses of ancestral chemical defenses. Colors code higher taxa as follows: blue, Pentazonia; red, Colobognatha; green, Juliforma; purple, Merochaeta; brown, Nematophora. See text for more detailed explanation. Tree diagram courtesy of Thomas Wesener. 


\begin{tabular}{|c|c|c|c|c|}
\hline Order & Family & Species & Chemical components & $\begin{array}{l}\text { Bibliographic } \\
\text { citations }\end{array}$ \\
\hline \multirow[t]{7}{*}{ Callipodida } & Abacionidae & Abacion magnum & p-cresol & Eisner et al 1963 \\
\hline & & Delophon georgianum & p-cresol & Shear et al 2007 \\
\hline & & Tetracion jonesi & p-cresol & Shear et al 2010 \\
\hline & & $\begin{array}{l}\text { Tetracion } \\
\text { tennesseensis }\end{array}$ & p-cresol & Peck 1989 \\
\hline & Callipodidae & Callipus foetidus & p-cresol & unpublished data \\
\hline & Schizopetalidae & Apfelbeckia insculpata & p-cresol & Curcic et al 2009 \\
\hline & & Callipodella fasciata & $\begin{array}{l}\text { p-cresol, phenol, p- } \\
\text { ethylphenol }\end{array}$ & $\begin{array}{l}\text { Makarov et al } \\
2011\end{array}$ \\
\hline \multirow[t]{2}{*}{ Glomerida } & Glomeridae & Glomeris marginata & glomerin, homoglomerin & $\begin{array}{l}\text { Schildknecht et al } \\
1966, \text { Meinwald } \\
\text { et al } 1966\end{array}$ \\
\hline & & Onomeris sinuata & glomerin, homoglomerin & Shear et al 2011 \\
\hline \multirow[t]{2}{*}{ ulida } & Blaniulidae & Blaniulus guttulatus & $\begin{array}{l}\text { 2-methyl, 1-4-benzoquinone, } \\
\text { 2-methyl-3-methoxy-1,4- } \\
\text { benzoquinone, hexadecyl } \\
\text { acetate, } \Delta \mathbf{9 - h e x a d e c e n y l} \\
\text { acetate, } \Delta \mathbf{9 - o c t a d e c e n y l} \\
\text { acetate }\end{array}$ & $\begin{array}{l}\text { Weatherston et al } \\
1971\end{array}$ \\
\hline & & Cibiulus phlepsii & $\begin{array}{l}\text { 2-methyl-1,4-benzoquinone, } \\
\text { 2-hydroxy-3-methyl-1,4- } \\
\text { benzoquinone, 2-methoxy-3- } \\
\text { methyl-1,4-benzoquinone, 2- } \\
\text { methylhydroquinone, 2,3- } \\
\text { dimethoxyhydroquinone, 2- } \\
\text { methyl-3,4- } \\
\text { methylenedioxyphenol, } \\
\text { 2,3-dimethoxy-3-methyl-1,4- } \\
\text { benzoquiinone, hexyl oleate, } \\
\text { octyl oleate }\end{array}$ & Vujisic et al 2014 \\
\hline
\end{tabular}


benzoquinone, 2-methoxy-3-

methyl-1,4-benzoquinone,

2,3-dimethoxyhydroquinone,

\section{2-methyl-3,4-}

\section{methylenedioxyphenol,}

2,3-dimethoxy-5-methyl-1,4-

benzoquinone, hexyl

oleate, octyl oleate

\begin{tabular}{|c|c|c|c|}
\hline Julidae & Allajulus dicentrus & $\begin{array}{l}\text { 2-hydroxy-3-methyl-1,4- } \\
\text { benzoquinone, 2-methoxy-3- } \\
\text { methyl-1,4-benzoquinone, } \\
\text { 2,3-dimethoxy-1,4- } \\
\text { benzoquinone, 2,3- } \\
\text { dimethoxy-5-methyl-1,4- } \\
\text { benzoquinone, (E)-2- } \\
\text { octenal, } 3 \text { other aliphatic } \\
\text { (E)-alkenals and their } \\
\text { corresponding alcohols }\end{array}$ & $\begin{array}{l}\text { Bodner and } \\
\text { Raspotnig } 2012\end{array}$ \\
\hline & $\begin{array}{l}\text { Anaulaciulus } \\
\text { okinawaensis }\end{array}$ & $\begin{array}{l}\text { 2-methyl-1,4-hydroquinone, } \\
\text { 2-methoxy-3-methyl-1,4- } \\
\text { benzoquinone, 2,3- } \\
\text { dimethoxy-5-methyl-1,4- } \\
\text { benzoquinone }\end{array}$ & $\begin{array}{l}\text { Kikunaga et al } \\
1993\end{array}$ \\
\hline & Anaulaciulus sp. & $\begin{array}{l}\text { 2-methyl-1,4-benzoquinone, } \\
\text { 2-methoxy-3-methl-1,4- } \\
\text { benzoquinone, 2-methoxy-6- } \\
\text { methyl-1,4-benzoquinone, n- } \\
\text { hexyl laurate, } \mathbf{1 4} \\
\text { additional } \mathbf{C}_{\mathbf{1 6 - 2 1}} \text { fatty acid } \\
\text { esters. }\end{array}$ & $\begin{array}{l}\text { Shimizu et al } \\
2012\end{array}$ \\
\hline
\end{tabular}


Cylindroiulus caeruliocinctus

1,4-benzoquinone, 2-methyl-

1,4-benzoquinone, 2-

methoxy-3-methyl-1,4-

benzoquinone, 2-methoxy-5-

methyl-1,4-benzoquinone, 2-

methoxy-6-methyl-1,4

benzoquione, 2-methoxy-1,4-

benzoquinone, 2,3-

dimethoxy-1,4-benzoquinone,

2,3-dimethoxy-5-methyl-1,4-

benzoquinone

2-methyl-1,4-benzoquinone,

Cylindroiulus

londinensis

(Cylindroiulus

teutonicus)

Cylindroiulus luridus 2-methyl-3-methoxy-1.4

benzoquinone 2-methylquinone, 2-methyl-
Röper \& Heyns

1977; Huth 2000

Cylindroiulus meinerti 3-methoxyquinone

Schildkencht \&

Weis 1961

1,4-benzoquinone, 2-methyl-

Röper \& Heyns

1,4-benzoquinone, 2-

methoxy-3-methyl-1,4-

benzoquinone, 2-methoxy-5-

methyl-1,4-benzoquinone, 2-

methoxy-6-methyl-1,4

benzoquione, 2-methoxy-1,4-

benzoquinone, 2,3-

dimethoxy-1,4-benzoquinone,

2,3-dimethoxy-5-methyl-1,4-

benzoquinone 
Cylindroiulus punctatus 1,4-benzoquinone, 2-methyl-

1,4-benzoquinone, 2-

methoxy-3-methyl-1,4-

benzoquinone, 2-methoxy-5-

methyl-1,4-benzoquinone, 2-

methoxy-6-methyl-1,4

benzoquione, 2-methoxy-1,4benzoquinone, 2,3-

dimethoxy-1,4-benzoquinone, 2,3-dimethoxy-5-methyl-1,4benzoquinone

2-methoxy-3-methyl-1,4-

benzoquinone, 2-methoxy-5-

methyl-1,4-benzoquinone, 2-

methoxy-6-methyl-1,4

benzoquione, 2-methoxy-1,4-

benzoquinone, 2,3-

dimethoxy-1,4-benzoquinone,

2,3-dimethoxy-5-methyl-1,4benzoquinone, Hexylesters

of alkanoic acids

2-methyl-3-methoxyquinone

Julus nitidus

Julus scandinavius 1,4-benzoquinone, 2-methyl-

1,4-benzoquinone, 2-

methoxy-3-methyl-1,4-

benzoquinone, 2-methoxy-5methyl-1,4-benzoquinone, 2methoxy-6-methyl-1,4

benzoquione, 2-methoxy-1,4benzoquinone, 2,3-

dimethoxy-1,4-benzoquinone 2,3-dimethoxy-5-methyl-1,4benzoquinone, hexylesters

of alkanoic acids
Röper \& Heyns

1977; Huth 2000
Röper \& Heyns

1977

Huth 2000 
1,4-benzoquinone, 2-

methoxy-3-methyl-1,4-

benzoquinone, 2-methoxy-5-

methyl-1,4-benzoquinone, 2-

methoxy-6-methyl-1,4

benzoquione, 2-methoxy-1,4-

benzoquinone, 2,3-

dimethoxy-1,4-benzoquinone,

2,3-dimethoxy-5-methyl-1,4-

benzoquinone,

Megaphyllum

2-methyl-1,4-benzoquinone,

unilineatus

2-methyl-3-methoxy-1,4

Schildkencht \&

(Chromatoiulus

benzoquinone

Weis 1961

unilineatus,

Brachyiulus

unilineatus)

Ommatoilus sabulosus

(Archiulus sabulosus)

2-methyl-1,4-benzoquinone,

2-methyl-3-methoxy-1,4

benzoquinone, 2-methyl-1,4-

hydroquinone, 2-methyl-3-

methoxy-1,4-hydroquinone

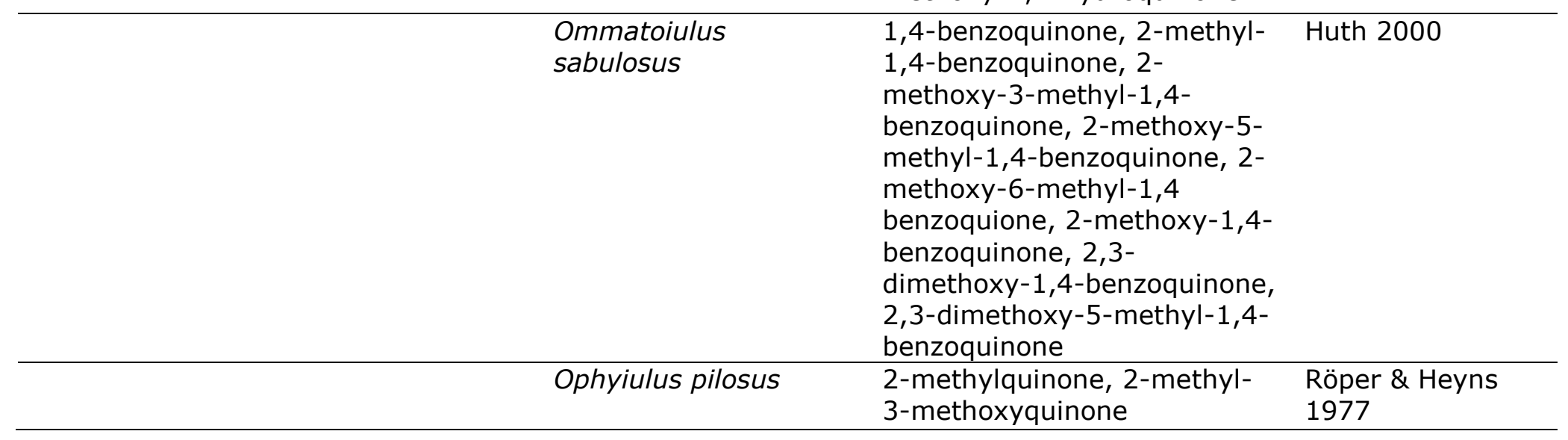


1,4-benzoquinone, 2-

methoxy-3-methyl-1,4-

benzoquinone, 2-methoxy-5-

methyl-1,4-benzoquinone, 2-

methoxy-6-methyl-1,4

benzoquione, 2-methoxy-1,4-

benzoquinone, 2,3-

dimethoxy-1,4-benzoquinone,

2,3-dimethoxy-5-methyl-1,4-

benzoquinone

Unciger foetidus 2-methylquinone, 2-methyl-

Röper \& Heyns 3-methoxyquinone

1977

Unciger transsilvanicus 2-methyl-1,4-benzoauiinone, Sekulic et al 2014

2-methoxy-3-methyl-1,4-

benzoquinone, 2-methyl-

\section{3,4-}

methylenedioxyphenol,

\section{phenol, p-cresol}

\begin{tabular}{|c|c|c|c|c|}
\hline & \multirow{3}{*}{ Parajulidae } & \multirow{3}{*}{$\begin{array}{l}\begin{array}{l}\text { Oriulus venustus ( } O . \\
\text { delus) }\end{array} \\
\text { Uroblaniulus candensis }\end{array}$} & \\
\hline & & & $\begin{array}{l}\text { 2-methyl-3-methoxy-1.4 } \\
\text { benzoquinone, o-cresol }\end{array}$ & $\begin{array}{l}\text { Kluge \& Eisner } \\
1971\end{array}$ \\
\hline & & & $\begin{array}{l}\text { 1,4-benzoquinone, } 2,3- \\
\text { dimethoxy-1,4-benzoquinone }\end{array}$ & $\begin{array}{l}\text { Weatherston \& } \\
\text { Percy } 1969\end{array}$ \\
\hline \multirow[t]{2}{*}{ Platydesmida } & Andrognathidae & Brachycybe lecontei & deoxybuzonamine & unpublished data \\
\hline & Platydesmidae & Platydesmus sp. & deoxybuzonamine & unpublished data \\
\hline \multirow[t]{6}{*}{ Polydesmida } & Cryptodesmidae & Niponia nodulosa & 1-octen-3-ol, geosmin & Omura et al 2002 \\
\hline & Doratodesmidae & $\begin{array}{l}\text { Eucondylodesmus } \\
\text { elegans }\end{array}$ & $\begin{array}{l}\text { (1E)-2-nitroethylbenzene, } \\
\text { (1Z)-2-nitroethylbenzene }\end{array}$ & $\begin{array}{l}\text { Kuwahara et al } \\
(2002)\end{array}$ \\
\hline & Euryuridae & Euryurus leachii & $\begin{array}{l}\text { HCN, benzaldehyde, guaiacol } \\
\text { (2-methoxyphenol) }\end{array}$ & $\begin{array}{l}\text { Duffield et al } \\
1974\end{array}$ \\
\hline & & Euryurus maculatus & $\begin{array}{l}\text { HCN?, Benzaldehyde, } \\
\text { mandelonitrile benzoate }\end{array}$ & Duffey et al 1977 \\
\hline & & $\begin{array}{l}\text { Euryurus maculatus } \\
\text { (E. australis) }\end{array}$ & $\begin{array}{l}\text { benzaldehyde, guaiacol (2- } \\
\text { methoxyphenol) }\end{array}$ & $\begin{array}{l}\text { Duffield et al } \\
1974\end{array}$ \\
\hline & Gomphodesmidae & Astrodesmus laxus & $\mathrm{HCN}$, benzaldehyde & Eisner et al 1975 \\
\hline
\end{tabular}




\begin{tabular}{|c|c|c|c|}
\hline & $\begin{array}{l}\text { Gomphodesmus } \\
\text { pavani }\end{array}$ & $\begin{array}{l}\text { HCN, benzaldehyde, benzoic } \\
\text { acid, mandelonitrile, } \\
\text { mandelonitrille benzoate }\end{array}$ & $\begin{array}{l}\text { Barbetta et al } \\
1966\end{array}$ \\
\hline \multirow[t]{2}{*}{ Nearctodesmidae } & $\begin{array}{l}\text { Leonardesmus } \\
\text { injucundus }\end{array}$ & p-cresol & Shear et al 2007 \\
\hline & Nearctodesmus salix & $\begin{array}{l}\text { HCN, benzaldehyde, 2- } \\
\text { methylbenzoic acid, 3- } \\
\text { methylbutanoic acid }\end{array}$ & $\begin{array}{l}\text { Wood \& Sorensen } \\
2005\end{array}$ \\
\hline \multirow[t]{7}{*}{ Paradoxosomatidae } & $\begin{array}{l}\text { Chamberlinius } \\
\text { hualienensis }\end{array}$ & $\begin{array}{l}\text { HCN?, mandelonitrile, benzoic } \\
\text { acid, mandelonitrile benzoate }\end{array}$ & $\begin{array}{l}\text { Kikunaga et al } \\
1993,\end{array}$ \\
\hline & $\begin{array}{l}\text { Chamberlinius } \\
\text { hualienensis }\end{array}$ & $\begin{array}{l}\text { HCN?, methyl benzoate, } \\
\text { benzaldehyde dimethy acetal, } \\
\text { phenol, p-cresol, guaiacol, } \\
\text { creosol }\end{array}$ & $\begin{array}{l}\text { Noguchi et al } \\
\text { 1997a;Taira \& } \\
\text { Arikoki } 2002\end{array}$ \\
\hline & $\begin{array}{l}\text { Neodyopus patrioticus } \\
\text { patrioticus }\end{array}$ & $\begin{array}{l}\text { HCN?, benzaldehyde, } \\
\text { mandelonitrile, phenol, p- } \\
\text { cresol }\end{array}$ & $\begin{array}{l}\text { Noguchi et al } \\
1997 b\end{array}$ \\
\hline & $\begin{array}{l}\text { Orthomorpha } \\
\text { coarctata }\end{array}$ & $\begin{array}{l}\text { HCN, benzaldehyde, benzoic } \\
\text { acid, phenol, guaiacol ( } 2- \\
\text { methoxyphenol) }\end{array}$ & $\begin{array}{l}\text { Monteiro } 1961, \\
\text { Taira et al } 2003\end{array}$ \\
\hline & Oxidus gracilis & $\begin{array}{l}\text { HCN, benzaldehyde, } \\
\text { mandelonitrile, phenol, p- } \\
\text { cresol, benzaldehyde } \\
\text { dimethyl acetal, cresol ( } 2 \text { - } \\
\text { methoxy-4-methyl phenol) }\end{array}$ & Taira et al 2003 \\
\hline & Oxidus gracilis & $\begin{array}{l}\text { HCN?, benzaldehyde, benzoic } \\
\text { acid, ethyl benzoate, phenol, } \\
\text { guaiacol }\end{array}$ & Duffey et al 1977 \\
\hline & $\begin{array}{l}\text { Streptogonopus } \\
\text { phipsoni }\end{array}$ & benzaldehyde & Bellairs et al 1983 \\
\hline Polydesmidae & Brachydesmus avalae & $\begin{array}{l}\text { HCN, benzoylnitrile, benzoic } \\
\text { acid, benzaldehyde, } \\
\text { mandelonitrile benzoate, } \\
\text { benzyl alcohol }\end{array}$ & $\begin{array}{l}\text { Makarov et al } \\
2010\end{array}$ \\
\hline
\end{tabular}




\begin{tabular}{|c|c|c|c|}
\hline & Brachydesmus dadayi & $\begin{array}{l}\text { HCN, benzoylnitrile, } \\
\text { benzaldehyde, mandelonitrile } \\
\text { benzoate, benzyl alcohol, } \\
\text { benzylethyl ketone }\end{array}$ & $\begin{array}{l}\text { Makarov et al } \\
2010\end{array}$ \\
\hline & $\begin{array}{l}\text { Epanerchodus } \\
\text { japonicus }\end{array}$ & $\begin{array}{l}\text { HCN, benzaldehyde, } \\
\text { mandelonitrile, phenol }\end{array}$ & Mori et al 1994 \\
\hline & Polydesmus collaris & $\begin{array}{l}\text { HCN, formic acid, acetic } \\
\text { acid, isovaleric acid, } \\
\text { benzaldehyde, benzoic acid, } \\
\text { mandelonitrile benzoate }\end{array}$ & Casnati et al 1963 \\
\hline & $\begin{array}{l}\text { Polydesmus } \\
\text { complanatus }\end{array}$ & $\begin{array}{l}\text { HCN, benzoylnitrile, } \\
\text { benzaldehyde, mandelonitrile, } \\
\text { benzylethyl ketone, } \\
\text { mandelonitrile benzoate, } \\
\text { benzylmethyl ketone }\end{array}$ & $\begin{array}{l}\text { Makarov et al } \\
2010\end{array}$ \\
\hline & $\begin{array}{l}\text { Pseudopolydesmus } \\
\text { canadensis ( } P . \\
\text { branneri) }\end{array}$ & $\mathrm{HCN}$ & Eisner et al 1975 \\
\hline & $\begin{array}{l}\text { Pseudopolydesmus } \\
\text { erasus }\end{array}$ & $\begin{array}{l}\text { HCN?, benzaldehyde, } \\
\text { mandeonitrile benzoate, ethyl } \\
\text { benzoate, phenol, guaiacol }\end{array}$ & Duffey et al 1977 \\
\hline & $\begin{array}{l}\text { Pseudopolydesmus } \\
\text { serratus }\end{array}$ & $\begin{array}{l}\text { HCN, isovaleric acid, } \\
\text { myristic acid, stearic acid, } \\
\text { benzaldehyde, mandelonitrile, } \\
\text { mandelonitrile benzoate, } \\
\text { benzoyl cyanide }\end{array}$ & $\begin{array}{l}\text { Wheeler } 1896 \\
\text { Eisner et al } 1963\end{array}$ \\
\hline Pyrgodesmidae & Thelodesmus armatus & $\begin{array}{l}\text { (1E)-2-nitroethylbenzene, } \\
\text { (1Z)-2-nitroethylbenzene }\end{array}$ & $\begin{array}{l}\text { Kuwahara et al } \\
(2002)\end{array}$ \\
\hline Sphaeriodesmidae & gen. et sp. & 4-nonanone & unpublished data \\
\hline Xystodesmidae & $\begin{array}{l}\text { "Fontaria virginiensis" } \\
\text { (probably Rudiloria } \\
\text { trimaculata or } \\
\text { Apheloria virginiensis } \\
\text { corrugata) }\end{array}$ & $\mathrm{HCN}$ & Eisner et al 1978 \\
\hline
\end{tabular}




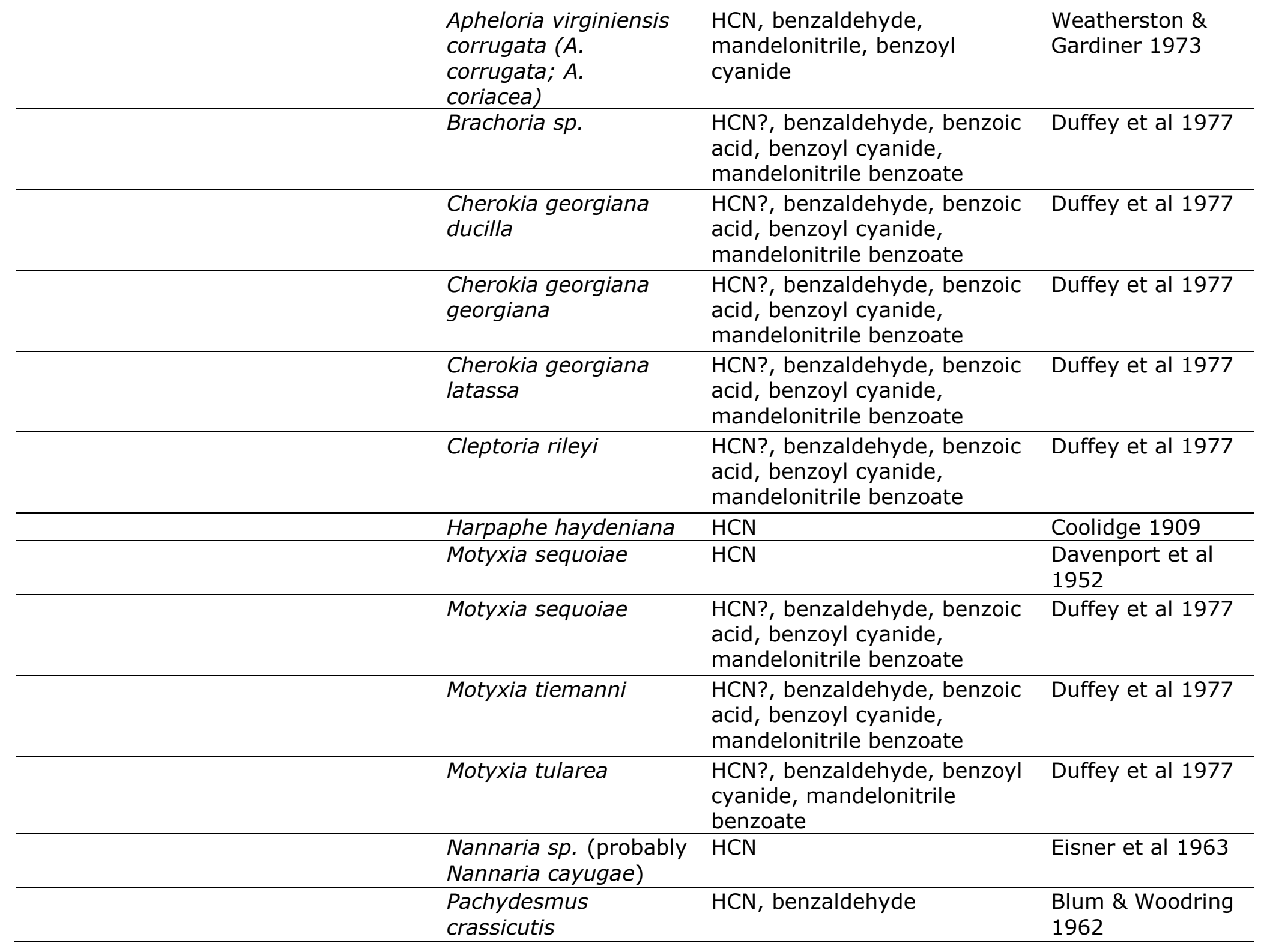


Paimokia sp.

Parafontaria laminata armigera

\begin{tabular}{|c|c|c|c|c|}
\hline & & $\begin{array}{l}\text { Parafontaria } \\
\text { tonominea }\end{array}$ & $\begin{array}{l}\text { HCN, benzaldehyde, } \\
\text { mandelonitrile }\end{array}$ & Ômura et al 2002 \\
\hline & & Pleuroloma flavipes & $\mathrm{HCN}$ & Wheeler 1896 \\
\hline & & $\begin{array}{l}\text { Rhysodesmus vicinus } \\
\text { (Polydesmus } \\
\text { [Fontaria] vicinus) }\end{array}$ & $\begin{array}{l}\mathrm{HCN}, p- \\
\text { isopropylmandelonitrile }\end{array}$ & Pallares 1945 \\
\hline & & Riukiaria pugionifera & $\begin{array}{l}\text { HCN?, mandelonitrile, benzoic } \\
\text { acid, benzaldehyde }\end{array}$ & $\begin{array}{l}\text { Kikunaga et al } \\
1993\end{array}$ \\
\hline & & $\begin{array}{l}\text { Riukiaria semicircularis } \\
\text { semicircularis }\end{array}$ & $\begin{array}{l}\text { HCN, benzaldehyde, } \\
\text { mandelonitrile, benzoyl } \\
\text { cyanide, mandelonitrile } \\
\text { benzoate }\end{array}$ & Ômura et al 2002 \\
\hline & & $\begin{array}{l}\text { Rudiloria kleinpeteri } \\
\text { (Apheloria kleinpeteri) }\end{array}$ & $\mathrm{HCN}$ & Eisner et al 1975 \\
\hline & & $\begin{array}{l}\text { Rudiloria trimaculata } \\
\text { (Apheloria } \\
\text { trimaculata) }\end{array}$ & $\begin{array}{l}\text { HCN, benzaldehyde, } \\
\text { mandelonitrile, benzoyl } \\
\text { cyanide }\end{array}$ & $\begin{array}{l}\text { Conner et al } \\
1977 \text {, Eisner et al } \\
1975\end{array}$ \\
\hline & & Sigiria $s p$. & $\begin{array}{l}\text { HCN?, benzaldehyde, benzoyl } \\
\text { cyanide }\end{array}$ & Duffey et al 1977 \\
\hline & & Sigmoria nantahalae & $\begin{array}{l}\text { HCN?, benzaldehyde, benzoic } \\
\text { acid, benzoyl cyanide }\end{array}$ & Duffey et al 1977 \\
\hline & & Stelgipus agrestis & $\begin{array}{l}\text { HCN?, benzaldehyde, } \\
\text { benzoyl cyanide }\end{array}$ & Duffey et al 1977 \\
\hline Polyzoniida & Hirudisomatidae & Kiusiozonium okai & $\begin{array}{l}\text { Polyzonimine, } \\
\text { nitropolyzonamine, } 0 \text { - } \\
\text { methyloxime } 236 \\
\text { (spiropyrrolizidine oxime) }\end{array}$ & $\begin{array}{l}\text { Kuwahara et al } \\
\text { (2007) }\end{array}$ \\
\hline & Polyzoniidae & Buzonium crassipes & $\begin{array}{l}\text { Buzonamine, B-pinene, } \\
\text { limonene }\end{array}$ & Wood et al 2000 \\
\hline
\end{tabular}

HCN?, benzaldehyde, benzoyl Duffey et al 1977 cyanide

benzaldehyde, mandelonitrile, Mori et al 1995 benzoyl cyanide,

mandelonitrile benzoate,

benzoic acid

mandelonitrile

HCN?, mandelonitrile, benzoic

Kikunaga et al

Riukiaria semicircularis

Rudiloria kleinpeteri

Rudiloria trimaculata

Apheloria

mandelonitrile, benzoyl

1977, Eisner et al

Duffey et al 1977

acid, benzoyl cyanide

.

(n)

. 


\begin{tabular}{|c|c|c|c|c|}
\hline & & $\begin{array}{l}\text { Petaserpes } \\
\text { cryptocephalus } \\
\text { (Polyzonium } \\
\text { rosalbum) }\end{array}$ & $\begin{array}{l}\text { Polyzonimine, } \\
\text { nitropolyzonamine }\end{array}$ & $\begin{array}{l}\text { Meinwald et al } \\
1975, \text { Smolanoff } \\
\text { et al } 1975\end{array}$ \\
\hline & & $\begin{array}{l}\text { Polyzonium } \\
\text { germanicum }\end{array}$ & Polyzonimine & Röper 1978 \\
\hline & Siphonotidae & Rhinotus purpureus & $\begin{array}{l}\text { O-methyloxime } 236 \\
\text { (spiropryrrolzidine oxime) }\end{array}$ & $\begin{array}{l}\text { Saporito et al } \\
2003\end{array}$ \\
\hline & & Siphonethus spp. & $\begin{array}{l}\text { polyzonimine oxime, new } \\
\text { compound }\end{array}$ & unpublished data \\
\hline Siphonocryptida & Siphonocryptidae & $\begin{array}{l}\text { Hirudicryptus } \\
\text { canariensis }\end{array}$ & $\begin{array}{l}\text { O-methyloxime } 236 \\
\text { (spiropryrrolzidine oxime) }\end{array}$ & unpublished data \\
\hline Siphonophorida & Siphonophoridae & Siphonophorus spp. & a-pinene, $\beta$-pinene & unpublished data \\
\hline \multirow[t]{6}{*}{ Spirobolida } & Floridobolidae & Floridobolus penneri & $\begin{array}{l}\text { 2-methyl-1,4-benzoquinone, } \\
\text { 2-methyl-3-methoxy-1.4 } \\
\text { benzoquinone }\end{array}$ & $\begin{array}{l}\text { Attygale et al } \\
1993\end{array}$ \\
\hline & Pachybolidae & $\begin{array}{l}\text { Epibolus pulchripes } \\
\text { (Metiche } \\
\text { tanganyikensis) }\end{array}$ & $\begin{array}{l}\text { 2-methyl-1,4-benzoquinone, } \\
\text { 2-methyl-3-methoxy-1.4 } \\
\text { benzoquinone, 2,3- } \\
\text { dimethoxy-1,4-benzoquinone, } \\
\text { 5-methyl-2,3-dimethoxy-1,4- } \\
\text { benzoquinone }\end{array}$ & Wood et al 1975 \\
\hline & & $\begin{array}{l}\text { Pachybolus } \\
\text { brachysternus }\end{array}$ & $\begin{array}{l}\text { 2-methyl-1,4-benzoquinone, } \\
\text { 2-methyl-3-methoxy-1.4 } \\
\text { benzoquinone }\end{array}$ & $\begin{array}{l}\text { De Bernardi et al } \\
1982\end{array}$ \\
\hline & & Pachybolus laminatus & 2-methyl-1,4-benzoquinone & $\begin{array}{l}\text { Barbier \& Lederer } \\
1957\end{array}$ \\
\hline & & Pelmatojulus tigrinus & $\begin{array}{l}\text { 2-methyl-1,4-benzoquinone, } \\
\text { 2-methoxy-3-methyl-1,4- } \\
\text { benzoquinone }\end{array}$ & $\begin{array}{l}\text { Schmitt et al } \\
2004\end{array}$ \\
\hline & & $\begin{array}{l}\text { Trigoniulus } \\
\text { lumbricinus }\end{array}$ & $\begin{array}{l}\text { 2-methyl-1,4-benzoquinone, } \\
\text { 2-methyl-3-methoxy-1.4 } \\
\text { benzoquinone }\end{array}$ & Monro et al 1962 \\
\hline
\end{tabular}




\begin{tabular}{|c|c|c|c|}
\hline Rhinocricldae & Acladocricus setigerus & $\begin{array}{l}\text { hydroquinone, 2- } \\
\text { methylhydroquinone, 2,3- } \\
\text { dimethoxyhydroquinone, 2- } \\
\text { methoxy-3- } \\
\text { methylhydroquionone, 2,3- } \\
\text { dimethoxy-5- } \\
\text { methylhydroquione, 2- } \\
\text { methyl-3,4- } \\
\text { methylenedioxyphenol }\end{array}$ & $\begin{array}{l}\text { Buden et al, } \\
2004 ; \text { Wu et al } \\
2007\end{array}$ \\
\hline & Rhinocricus duvernoyi & $\begin{array}{l}\text { 2-methyl-3-methoxy-1,4 } \\
\text { benzoquinone }\end{array}$ & Ubik et al. 1982 \\
\hline & Rhinocricus insulata & $\begin{array}{l}\text { trans-2-dodecanal, 2- } \\
\text { methyl-1,4-benzoquinone }\end{array}$ & $\begin{array}{l}\text { Wheeler et al } \\
1964\end{array}$ \\
\hline & Rhinocricus padbergi & $\begin{array}{l}\text { 2-methyl-1,4-benzoquinone, } \\
\text { 3,3a,4,5-tetrahydro-1H-- } \\
\text { pyrrolo-[2,3b] pyridine- } \\
\text { 2,6-dione }\end{array}$ & Arab et al 2003 \\
\hline & Rhinocricus padbergi & $\begin{array}{l}\text { 2-methyl-quinone, 2-methyl- } \\
\text { hydroquiinone, 2-methyl-3- } \\
\text { methoxy-quinone, 2-methyl- } \\
\text { 3-methoxy-hydroquinone }\end{array}$ & Röper 1978 \\
\hline & Rhinocricus $s p$. & $\begin{array}{l}\text { 2-methyl-1,4-benzoquinone, } \\
\text { 2-methyl-3-methoxy-1,4 } \\
\text { benzoquinone }\end{array}$ & $\begin{array}{l}\text { Schildkencht \& } \\
\text { Weis } 1961\end{array}$ \\
\hline & Rhinocricus varians & 2-methyl-1,4-benzoquinone & $\begin{array}{l}\text { Mousstaché et al. } \\
1969\end{array}$ \\
\hline Spirobolidae & Chicobolus spinigerus & $\begin{array}{l}\text { 2-methyl-1,4-benzoquinone, } \\
\text { 2-methyl-3-methoxy-1,4 } \\
\text { benzoquinone }\end{array}$ & Monro et al 1962 \\
\hline & Narceus annularis & $\begin{array}{l}\text { 2-methyl-1,4-benzoquinone, } \\
\text { 2-methyl-3-methoxy-1,4 } \\
\text { benzoquinone }\end{array}$ & $\begin{array}{l}\text { Monro et al 1962, } \\
\text { Percy \& } \\
\text { Weatherston } \\
1971\end{array}$ \\
\hline & Narceus gordanus & $\begin{array}{l}\text { 2-methyl-1,4-benzoquinone, } \\
\text { 2-methyl-3-methoxy-1,4 } \\
\text { benzoquinone }\end{array}$ & Monro et al 1962 \\
\hline
\end{tabular}


Spirobolus joanniae (Prospirobolus joanniae)

Spirostreptida Cambalidae Cambala hubrichti

gen. et $s p$. 2-methyl-1,4-hyrodquinone, 1-methoxy-3-methyl-1,4benzoquinone

2-methyl-1,4-benzoquinone, 2-methyl-3-methoxy-1.4

benzoquinone

toluquinone (2-methyl

benzoquinone), 2-methoxy-3-

methyl benzoquinone, 2,3-

dimethoxybenzoquinone,

toluhydroquinone

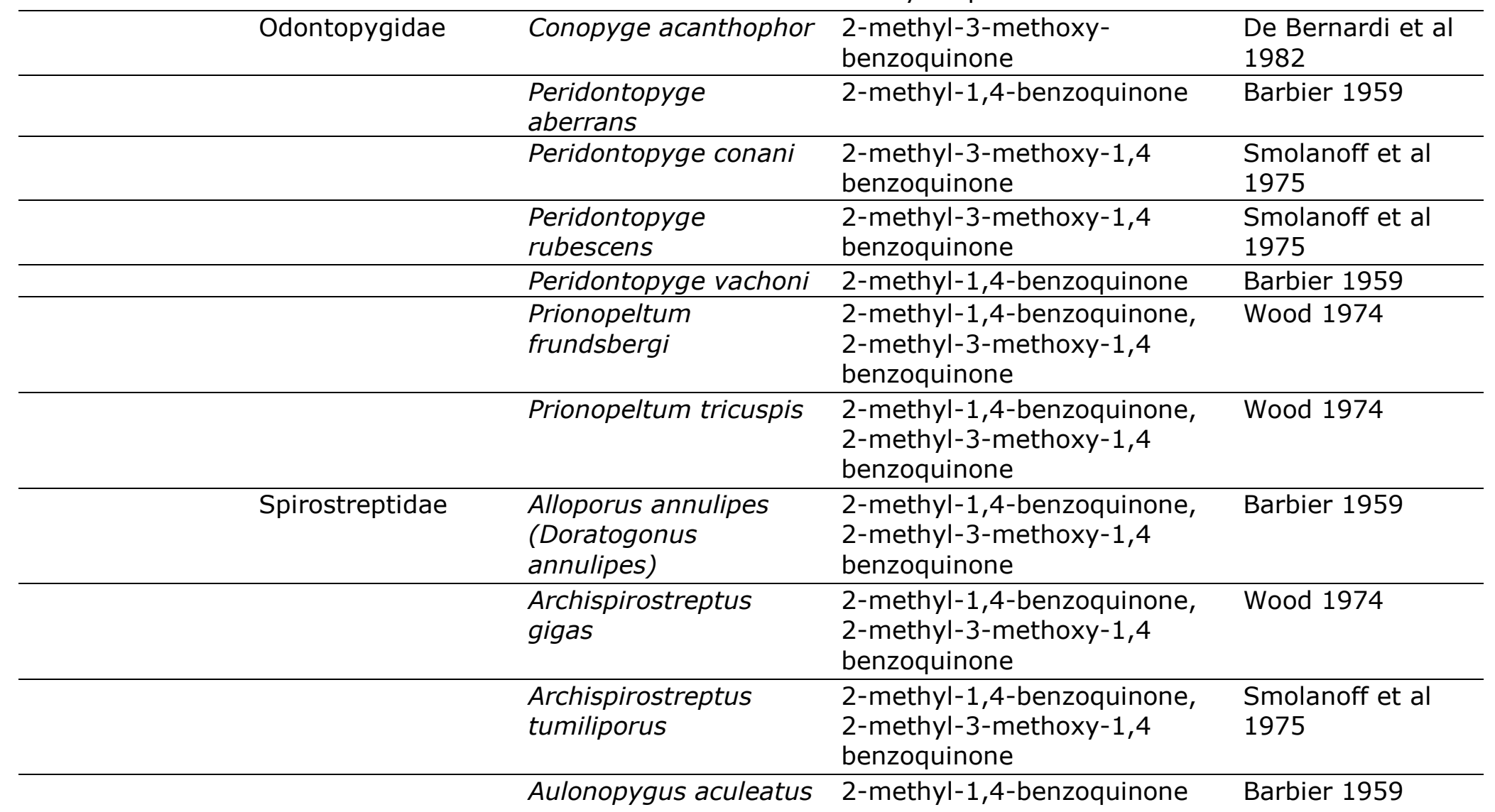

Kikunaga et al 1993

Eisner et al 1965

Deml \& Huth

1999

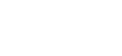

$+$




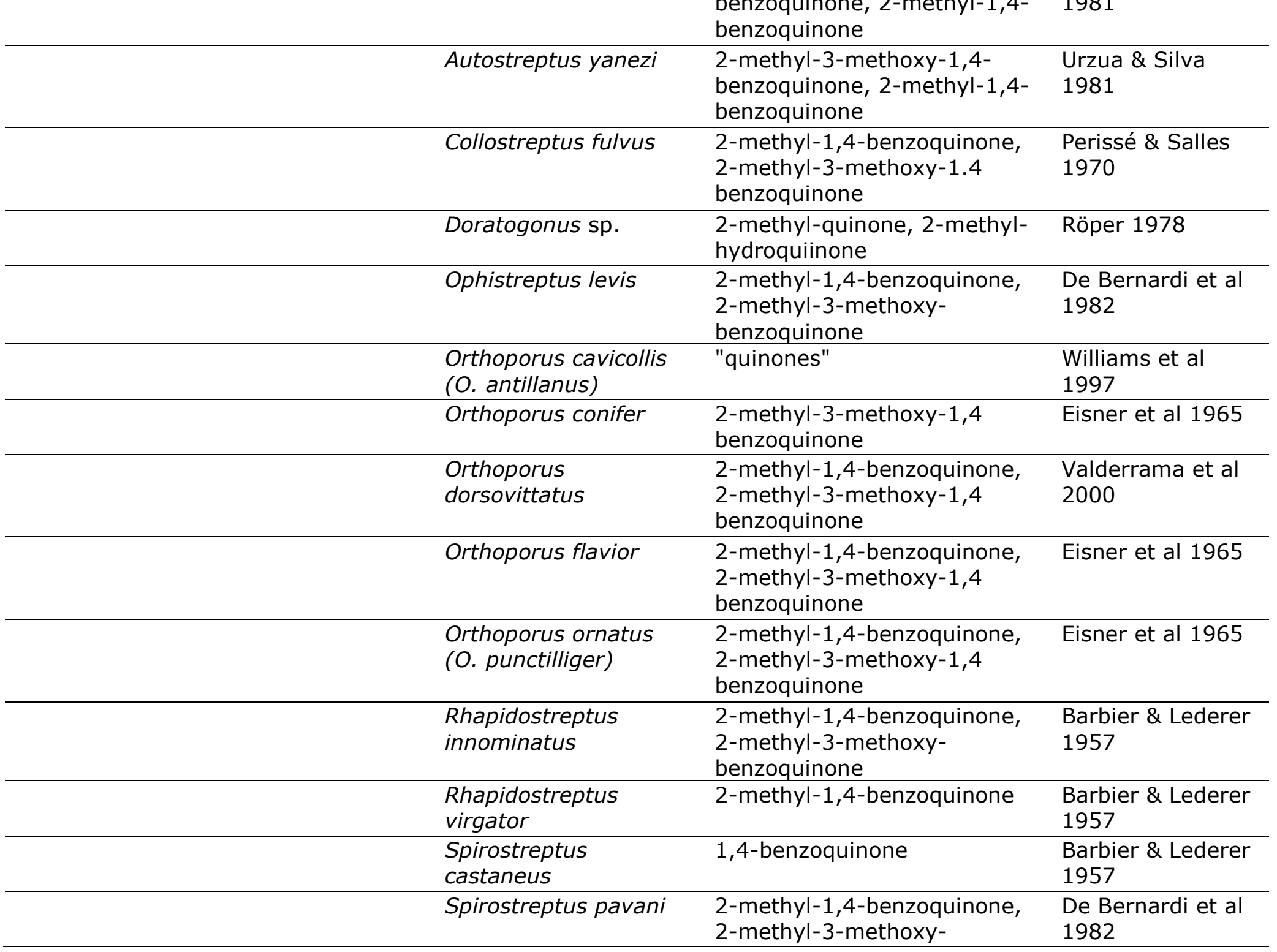

Autostreptus chilensis

2-methyl-3-methoxy-1,4- Urzua \& Silva benzoquinone, 2-methyl-1,4- 1981 enzoquinone

2-methyl-1,4-benzoquinone, Perissé \& Salles

2-methyl-quinone, 2-methyl- Röper 1978

illiams et al

(O. antillanus)

2-methyl-1,4-benzoquinone,

Orthoporus flavior

2-methyl-1,4-benzoquinone

Orthoporus ornatus

2-methyl-1,4-benzoquinone

Barbier \& Ledere

Barbier \& Lederer

Barbier \& Lederer

2-methyl-3-methoxy-

1982 


\section{benzoquinone}

\begin{tabular}{|c|c|c|c|c|}
\hline & & Spirostrophus naresi & $\begin{array}{l}\text { toluquinone ( } 2 \text {-methyl } \\
\text { benzoquinone) }\end{array}$ & Périssé et al 1968 \\
\hline & & Telodeinopus aoutii & $\begin{array}{l}\text { toluquinone (2-methyl } \\
\text { benzoquinone), 2-methoxy-3- } \\
\text { methyl benzoquinone, 2,3- } \\
\text { dimethoxybenzoquinone, } \\
\text { toluhydroquinone }\end{array}$ & $\begin{array}{l}\text { Deml \& Huth } \\
1999\end{array}$ \\
\hline \multirow[t]{2}{*}{ Stemmiulida } & Stemmiulidae & Prostemmiulus loomisi & p-cresol & unpublished data \\
\hline & & Stemmiulus spp. & p-cresol & unpublished data \\
\hline
\end{tabular}




\begin{tabular}{|c|c|c|}
\hline Order & Family & Chemical components \\
\hline \multirow[t]{3}{*}{ Callipodida } & Abacionidae & p-cresol \\
\hline & Callipodidae & p-cresol \\
\hline & Schiizopetalidae & p-cresol \\
\hline Glomerida & Glomeridae & $\begin{array}{l}\text { glomerin, homoglomerin } \\
\text { (quinazolinone alkaloids) }\end{array}$ \\
\hline \multirow[t]{3}{*}{ Julida } & Blaniulidae & $\begin{array}{l}\text { 2-methyl, 1-4-benzoquinone, } \\
\text { 2-methyl-3-methoxy-1,4- } \\
\text { benzoquinone, hexadecyl } \\
\text { acetate, } \Delta 9 \text {-hexadecenyl } \\
\text { acetate, } \Delta 9 \text {-octadecenyl } \\
\text { acetate }\end{array}$ \\
\hline & Julidae & $\begin{array}{l}\text { Substituted hydroquinones } \\
\text { and benzoquinones, } \\
\text { hexylesters of alkanoic acids }\end{array}$ \\
\hline & Parajulidae & $\begin{array}{l}\text { 1,4 benzoquinone, } 2,3- \\
\text { dimethoxy-1-4- } \\
\text { benzoquinone, o-cresol }\end{array}$ \\
\hline \multirow[t]{8}{*}{ Polydesmida } & Cryptodesmidaae & 1-octen-3-ol, geosmin \\
\hline & Doratodesmidae & $\begin{array}{l}\text { (1E)-2-nitroethylbenzene, } \\
\text { (1Z)-2-nitroethylbenzene }\end{array}$ \\
\hline & Euryuridae & $\begin{array}{l}\text { HCN, benzaldehyde, } \\
\text { madelonitrile, guaiacol (2- } \\
\text { methoxyphenol) }\end{array}$ \\
\hline & Gomphodesmidae & $\begin{array}{l}\text { HCN, benzaldehyde, benzoic } \\
\text { acid, mandelonitrile, } \\
\text { mandelonitrille benzoate }\end{array}$ \\
\hline & Nearctodesmidae & $\begin{array}{l}\text { HCN, benzaldehyde, 2- } \\
\text { methylbenzoic acid, 3- } \\
\text { methylbutanoic acid, p- } \\
\text { cresol }\end{array}$ \\
\hline & Paradoxosomatidae & $\begin{array}{l}\text { HCN, methyl benzoate, } \\
\text { benzaldehyde dimethyl } \\
\text { acetal, benzoic acid, } \\
\text { benzaldehyde, ethyl } \\
\text { benzoate, phenol, p-cresol, } \\
\text { guaiacol, cresol }\end{array}$ \\
\hline & Polydesmidae & $\begin{array}{l}\text { HCN, benzoylnitrile, } \\
\text { benzaldehyde,mandelonitrile, } \\
\text { manelonitrile benzoate, } \\
\text { benzyl alcohol, benzylmethyl } \\
\text { ketone, benzylethyl ketone, } \\
\text { phenol, guaiacol, formic acid, } \\
\text { acetic acid, isovaleric acid, } \\
\text { myristic acid, stearic acid }\end{array}$ \\
\hline & Pyrgodesmidae & $\begin{array}{l}\text { (1E)-2-nitroethylbenzene, } \\
\text { (1Z)-2-nitroethylbenzene }\end{array}$ \\
\hline
\end{tabular}




\begin{tabular}{|c|c|c|}
\hline & Xystodesmidae & $\begin{array}{l}\text { HCN, benzaldehyde, benzoic } \\
\text { acid, benzoyl cyanide, } \\
\text { mandelonitrile benzoate, p- } \\
\text { isopropylmandelonitrile, }\end{array}$ \\
\hline \multirow[t]{3}{*}{ Polyzoniida } & Hirudisomatidae & $\begin{array}{l}\text { Polyzonimine, } \\
\text { nitropolyzonimine, } 0- \\
\text { methyloxime } 236 \\
\text { (spiropyrrolizidine oxime) }\end{array}$ \\
\hline & Polyzoniidae & $\begin{array}{l}\text { Polyzonimine, } \\
\text { nitropolyzonimine, } \\
\text { buzonimine, B-pinene, } \\
\text { limonene }\end{array}$ \\
\hline & Siphonotidae & $\begin{array}{l}\text { Polyzonimine, } \\
\text { nitropolyzonimine, O- } \\
\text { methyloxime } 236 \\
\text { (spiropyrrolizidine oxime) }\end{array}$ \\
\hline Siphonocryptida & Siphonocryptidae & $\begin{array}{l}\text { O-methyloxime } 236 \\
\text { (spiropyrrolizidine oxime) }\end{array}$ \\
\hline Siphonophorida & Siphonophoridae & a-pinene, B-pinene \\
\hline \multirow[t]{4}{*}{ Spirobolida } & Floridobolidae & $\begin{array}{l}\text { 2-methyl-1,4-benzoquinone, } \\
\text { 2-methyl-3-methoxy-1.4 } \\
\text { benzoquinone }\end{array}$ \\
\hline & Pachybolidae & $\begin{array}{l}\text { 2-methyl-1,4-benzoquinone, } \\
\text { 2-methyl-3-methoxy-1.4 } \\
\text { benzoquinone, 2,3- } \\
\text { dimethoxy-1,4- } \\
\text { benzoquinone, 5-methyl-2,3- } \\
\text { dimethoxy-1,4-benzoquinone }\end{array}$ \\
\hline & Rhinocricidae & $\begin{array}{l}\text { 2-methyl-1,4-benzoquinone, } \\
\text { 2-methyl-3-methoxy-1.4 } \\
\text { benzoquinone, trans-2- } \\
\text { dodecanal, 3- }\end{array}$ \\
\hline & Spirobolidae & $\begin{array}{l}\text { 2-methyl-1,4-benzoquinone, } \\
\text { 2-methyl-3-methoxy-1.4 } \\
\text { benzoquinone }\end{array}$ \\
\hline \multirow[t]{4}{*}{ Spirostreptida } & Cambalidae & $\begin{array}{l}\text { 2-methyl-1,4-benzoquinone, } \\
\text { 2-methyl-3-methoxy-1.4 } \\
\text { benzoquinone }\end{array}$ \\
\hline & Harpagophoridae & $\begin{array}{l}\text { toluquinone (2-methyl } \\
\text { benzoquinone), 2-methoxy- } \\
\text { 3-methyl benzoquinone, 2,3- } \\
\text { dimethoxybenzoquinone, } \\
\text { toluhydroquinone }\end{array}$ \\
\hline & Odontopygidae & $\begin{array}{l}\text { 2-methyl-1,4-benzoquinone, } \\
\text { 2-methyl-3-methoxy-1.4 } \\
\text { benzoquinone }\end{array}$ \\
\hline & Spirostreptidae & $\begin{array}{l}\text { 2-methyl-1,4-benzoquinone, } \\
\text { 2-methoxy-3-methyl-1,4- } \\
\text { benzoquinone, } \\
\text { hydroquinone, 2-methyl }\end{array}$ \\
\hline
\end{tabular}


hydroquinone, 2,3-

dimethoxyhydroquinone, 2-

methoxy-3-

methylhydroquinone, 2,3-

dimethoxy-5-

methylhydroquinone 


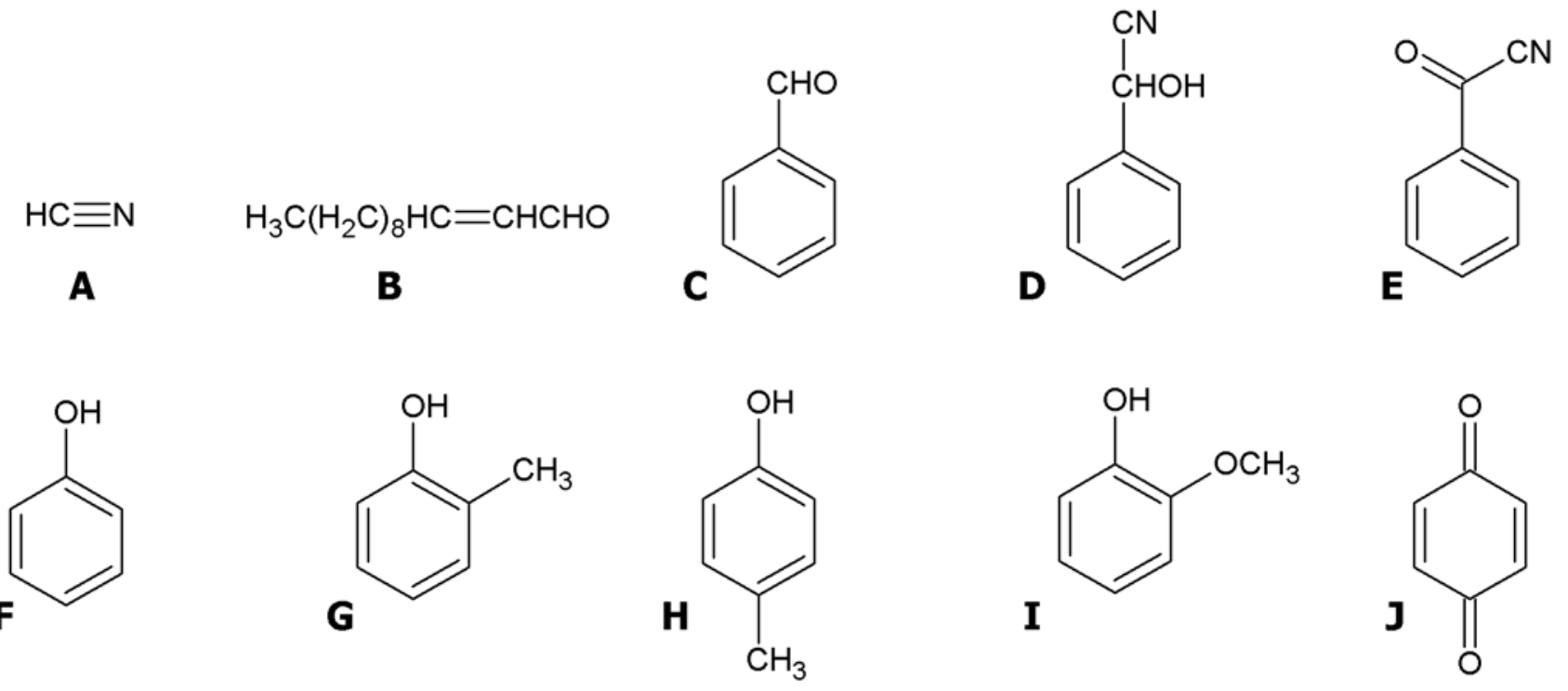<smiles></smiles><smiles>CCc1nc(=O)c2ccccc2n1C</smiles><smiles>CC1(C)CCCC12C=NCC2</smiles><smiles>CC1(C)CCCC12CCN1CCC([N+](=O)[O-])C12</smiles> 
Figure 2
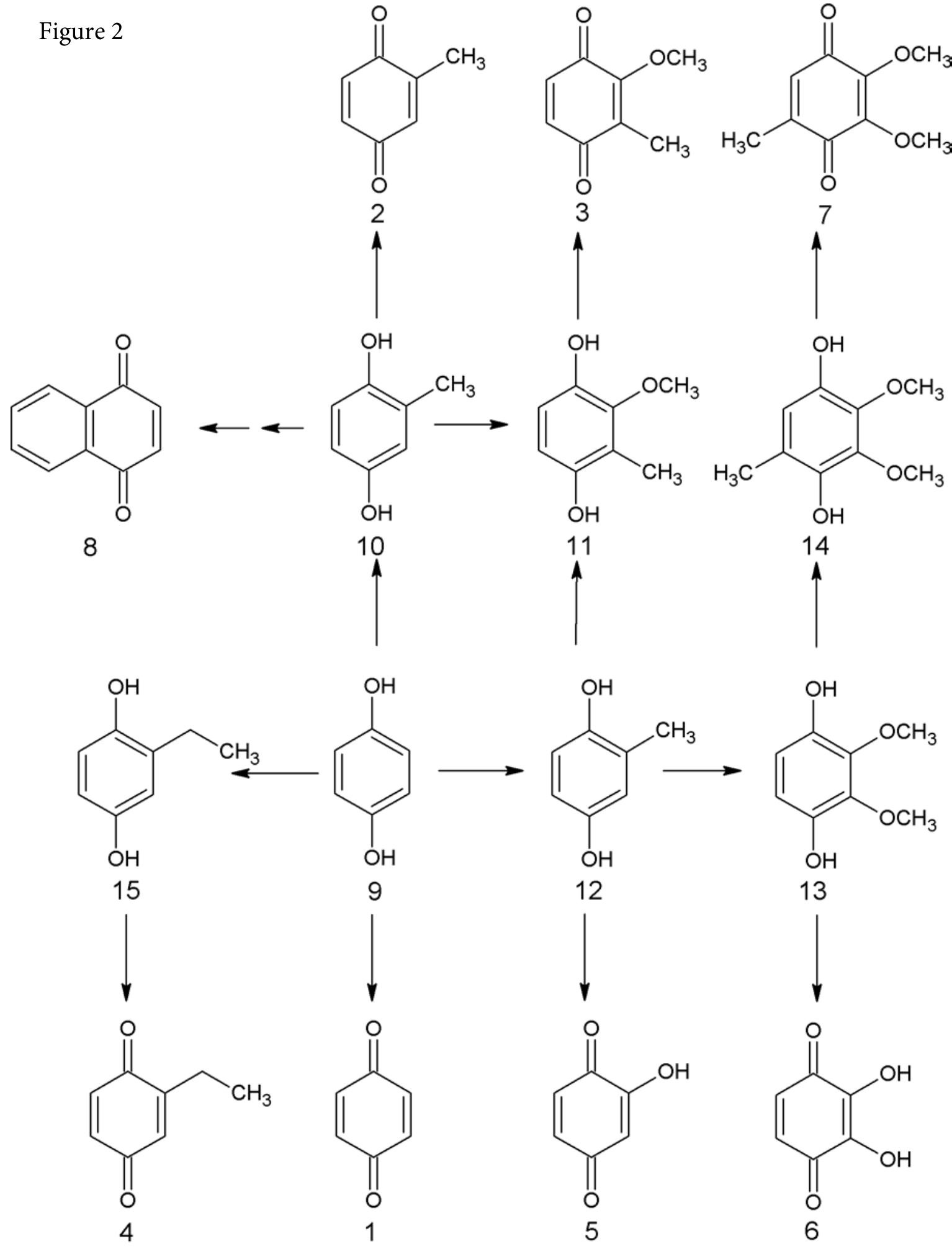


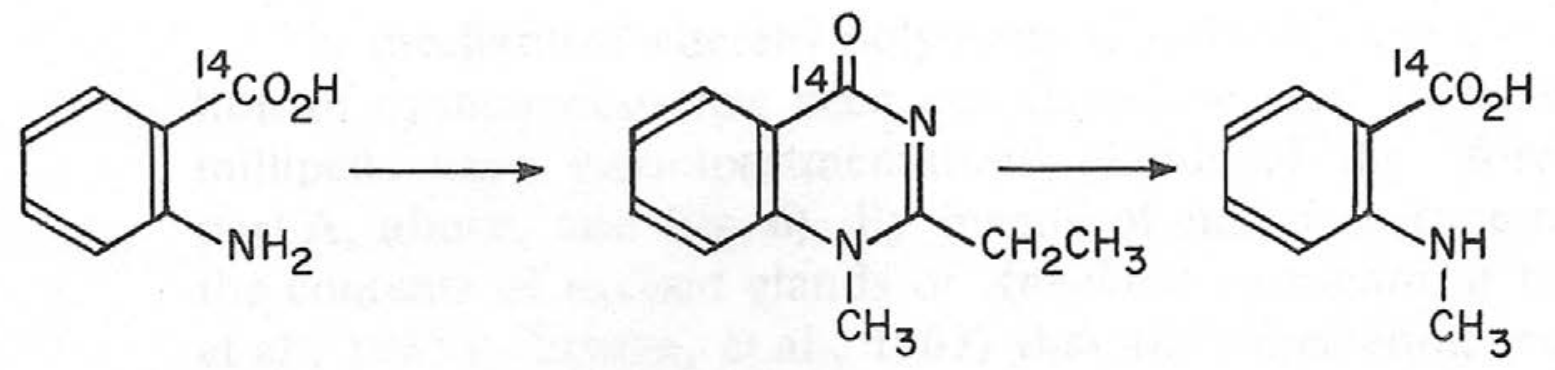

Figure 6
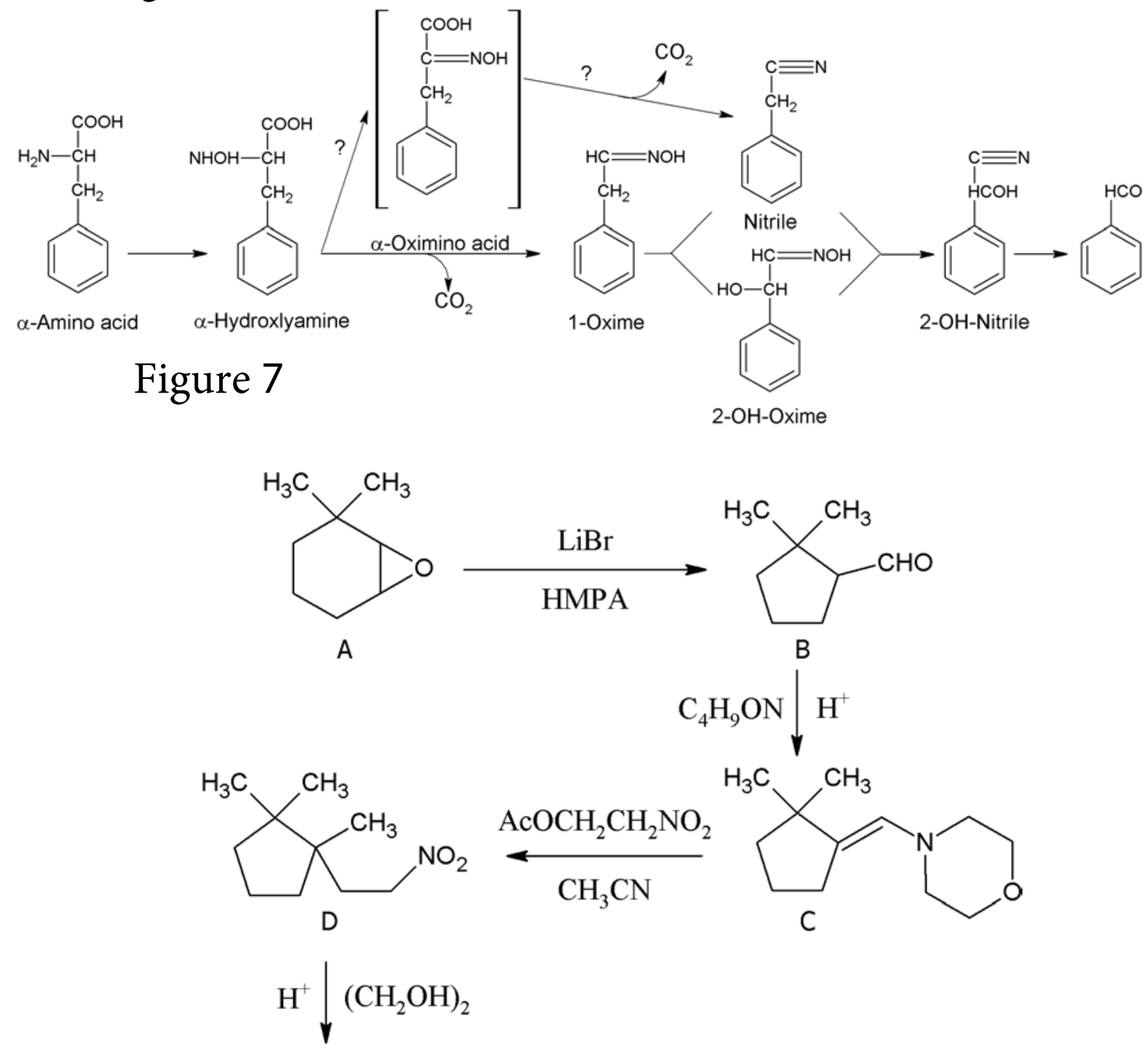

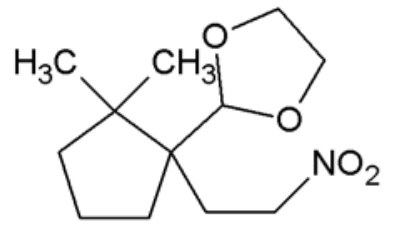

E

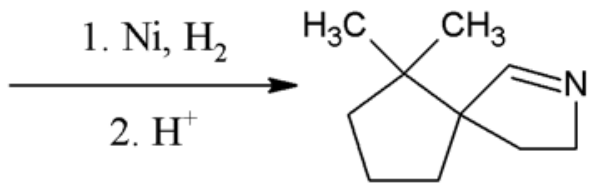

$\mathrm{F}$

Figure 8 
figure 16 



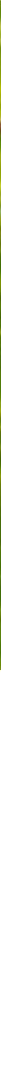




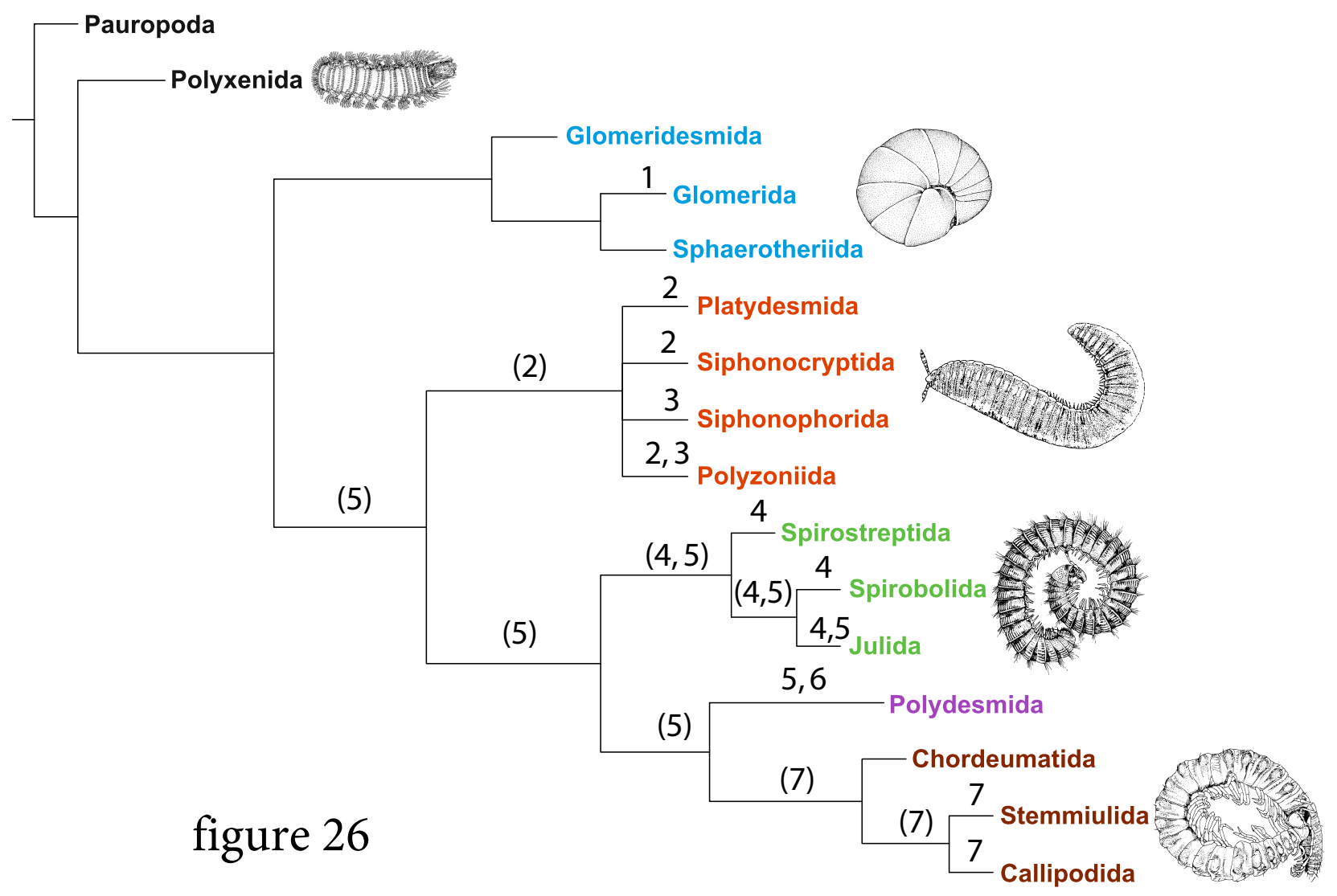

